LUANA DI BEO RODRIGUES

REÚSO DE ÁGUA EM SISTEMAS AEROPORTUÁRIOS UTILIZANDO O PROCESSO DE ULTRAFILTRAÇÃO

SÃO PAULO

2012 
LUANA DI BEO RODRIGUES

\section{REÚSO DE ÁGUA EM SISTEMAS AEROPORTUÁRIOS UTILIZANDO O PROCESSO DE ULTRAFILTRAÇÃO}

Dissertação apresentada à Escola Politécnica da Universidade de São Paulo para obtenção do título de Mestre em Engenharia

Área de Concentração: Engenharia Civil

Orientador: Prof. Doutor José Carlos Mierzwa

SÃO PAULO

2012 
Este exemplar foi revisado e alterado em relação à versão original, sob responsabilidade única do autor e com a anuência de seu orientador.

São Paulo, 20 de outubro de 2012

Assinatura do autor

Assinatura do orientador

FICHA CATALOGRÁFICA

\section{Rodrigues, Luana Di Beo}

Reuso de água em sistemas aeroportuários utilizando o processo de ultrafiltração / L.D.B. Rodrigues. -- São Paulo, 2012. $103 \mathrm{p}$.

Dissertação (Mestrado) - Escola Politécnica da Universidade de São Paulo. Departamento de Engenharia Hidráulica e Ambiental.

1.Reuso da água 2.Aeroportos 3.Ultrafiltração I.Universidade de São Paulo. Escola Politécnica. Departamento de Engenharia Hidráulica e Ambiental II.t. 


\section{DEDICATÓRIA}

Dedico este trabalho aos meus filhos Letícia e Ivan e ao meu marido Paulo pelo carinho e compreensão dispensados ao longo desses anos. 


\section{AGRADECIMENTOS}

Ao Professor José Carlos Mierzwa pela orientação, pelo incentivo e principalmente por seu profissionalismo.

Ao professor Ivanildo Hespanhol pela oportunidade, pela confiança e por estar disposto a ajudar sempre com grande satisfação.

A minha mãe por caminhar incansavelmente ao meu lado nunca deixando que eu desista dos meus sonhos.

Ao meu pai pelo incentivo.

A minha irmã Nara e aos meus sobrinhos Victor e Luíza pelo apoio nos momentos difíceis.

Aos meus amigos Maurício, Eduardo e Luciana, pelo companheirismo e a todos do CIRRA que contribuíram com o desenvolvimento desse trabalho.

Aos colegas Jair Souza e Anderson Verholeack, técnicos em automação, pela impagável ajuda.

Ao Sérgio, Izadora e Carlos Maurício da empresa Koch Membranas pelo auxílio na realização da pesquisa.

À empresa Schneider por fornecer o software utilizado na pesquisa

A Karina, Simone, Márcia, Edísio, Marcel e Ana Paula da empresa EP Analítica, pela paciência e pelo profissionalismo. 
"Palor das coisas não está no tempo que elas duram, mas na intensidade com que acontecem. Por isso existem momentos inesqueciveis. coisas inexplicáveis e pessoas incomparáveis (Feinando Sabino) 


\section{RESUMO}

O intenso crescimento populacional associado à demanda excessiva de água, principalmente em grandes centros urbanos, tem comprometido de forma significativa os recursos hídricos tornando-os escassos em muitas regiões. Frente a este cenário a adoção de medidas que proporcionem a conservação da água nas diversas atividades nas quais ela é utilizada é de grande relevância. Neste contexto, medidas como o uso racional e a prática do reúso de água são opções que devem ser consideradas para combater a escassez induzida. No caso do reúso de água é possível utilizar efluentes, tratados ou não, como fonte alternativa às demandas para usos menos restritivos, preservando a água de melhor qualidade para aplicações mais nobres, como o consumo humano. Assim, neste trabalho foi avaliada a viabilidade técnica da utilização de efluentes secundários submetidos ao tratamento complementar por membranas de ultrafiltração, do tipo fibra oca, para atendimento de demandas não potáveis em sistemas aeroportuários. O estudo foi desenvolvido através da operação de uma unidade piloto de membranas, instalada na saída do sistema de esgotamento sanitário do Aeroporto Internacional de São Paulo/Guarulhos - Governador André Franco Montoro,. Por meio de ensaios específicos as condições ótimas de operação foram estabelecidas, pressão de 0,9 bar $(90 \mathrm{kPa})$, frequência de retrolavagem de 40 minutos e frequência de limpeza de $200 \mathrm{~h}$, sendo que a taxa de recuperação de água no sistema permaneceu em torno de $70 \%$. O desempenho do sistema em relação à remoção de contaminantes foi avaliado verificando-se as porcentagens de remoção de Cor, Turbidez, $\mathrm{DBO}_{5,20}, \mathrm{DQO}$, Carbono Orgânico Dissolvido, Absorbância de radiação UV (254 nm) e Coliformes Termotolerantes, obtendo-se remoções de 89\%, 99\%, 70\%, $78 \%, 80 \%, 36 \%$ e $100 \%$, respectivamente. Com base nos resultados das análises foi possível concluir que a água produzida pelo sistema de membranas apresenta potencial para atender aos seguintes usos não potáveis: irrigação de áreas verdes, descargas em bacias sanitárias e mictórios, , lavagem de pitas e reserva para combate a incêndios. Como a água produzida pelo sistema de membranas apresentou concentrações elevadas de Nitrogênio Amoniacal, Fosfato e Matéria orgânica recomenda-se um estudo mais detalhado da estação de tratamento biológico, antes de utilizár para atender a esse fim. 
Palavras-chave: reúso de água, ultrafiltração, sistemas aeroportuários 


\section{ABSTRAC}

The excessive demand for water associated with intense population growth, principally in large urban centers, has significantly compromised water resources and transformed the situation in many regions to a scarcity status. Faced with this scenario, it is of great relevance to adopt measures that promote the conservation of water, through various activities and uses. In this context, rational water use and water reuse are measures that should be considered to tackle the induced shortage. In the case of water reuse, it is possible to use effluents, treated or untreated, as an alternate source for uses that have less stringent quality standards. This in turn, preserves the higher quality water for more demanding water uses, such as human consumption. In this study, we evaluated the technical feasibility of the use of secondary effluents, subjected to ultrafiltration membrane treatment (hollow fiber), to meet the non-potable demands of airport systems. The study was conducted with a pilot plant membrane, installed and operated at the sewage system discharge at the International Airport of São Paulo/Guarulhos Governor André Franco Montoro. Specific tests were conducted to establish optimum operation conditions: 0.9 bar $(90 \mathrm{kPa})$ of pressure, a backwash frequency of 40 minutes, a cleaning frequency of 200 hours, and a recovery rate maintained around $70 \%$. The system performance with respect to contaminant removal was evaluated by determining the percent removal of color, turbidity, BOD5, 20, COD, dissolved organic carbon, UV Absorbance (254 nm), and coliform, which yielded removals of $89 \%, 99 \%, 70 \%, 78 \%$, $80 \%, 36 \%$, and $100 \%$, respectively. Based on analysis results, it was concluded that the water produced by the membrane system has the potential to supply the following non-potable uses: irrigation of green areas, discharges in toilets and urinals, floor washing, and firefighting reserves. As the water produced by the membrane system had high concentrations of ammoniacal nitrogen, phosphate, and organic matter, a more detailed study is recommended before using the effluent in cooling towers.

Keywords: Water reuse, ultrafiltration, airport systems 


\section{LISTA DE FIGURAS}

Figura 1- Potencial de conflitos gerados pelo uso da água nas principais regiões brasileiras, inclusive a Região Metropolitana de São Paulo

Figura 2 - Diagrama para desenvolvimento de um plano de conservação e reúso de água

Figura 3 - Unidades de tratamento utilizando a tecnologia de separação por membranas de Microfiltração (MF) e Ultrafiltração (UF) de 1995 a 2003 .36

Figura 4 - Representação dos três fluxos relativos ao processo de separação por membranas .38

Figura 5 - Módulos compostos por membranas de placas planas 39

Figura 6 - Cartucho de membrana enrolada em espiral, adaptado de 40

Figura 7 - Esquema da operação de módulos compostos por membranas de fibra oca,

Figura 8 - Módulos de membranas tubulares

Figura 9 - Capacidade de retenção de contaminantes apresentada pelas membranas. 44

Figura 10 - Representação esquemática do tipo de separação de sólidos .46

Figura 11 - Seção transversal de uma membrana assimétrica .50

Figura 12 - Representação do ângulo de contato entre a gota de água e a superfície da membrana

Figura 13 - Relação entre a pressão e o fluxo de permeado nas membranas de OR e $\mathrm{NF}$

Figura 14 Relação entre a pressão e o fluxo de permeado nas membranas de MF e UF .54

Figura 15 - Esquema simplificado de variação do fluxo em um processo de separação por membranas operando em sistema deadend e crossflow .56

Figura 16 - Representação do perfil de concentração de soluto em função velocidade de escoamento ao longo da seção transversal de uma membrana tubular operando com sistema crossflow

Figura 17 - Esquema simplificado da Teoria do filme - Modelo de transferência de massa 


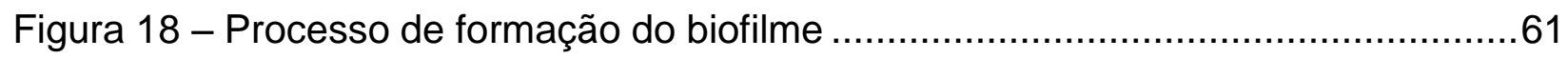

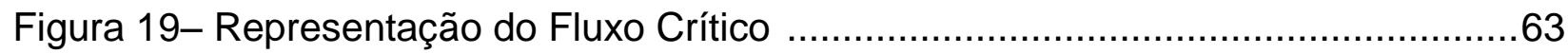

Figura 20- Fator de Concentração em função do Fator de Redução de Volume do concentrado.

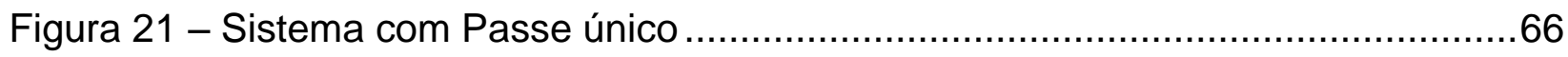

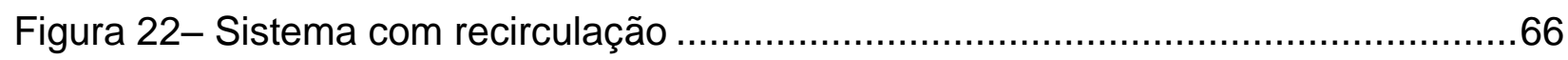

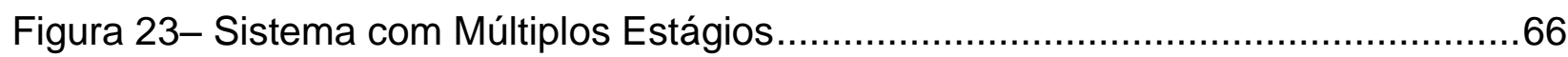

Figura 24 - Estação de tratamento de esgoto sanitário do Aeroporto Internacional de

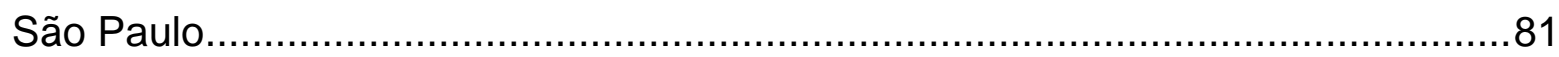

Figura 25 - Esquema do sistema de tratamento do efluente aeroportuário do AISP......82

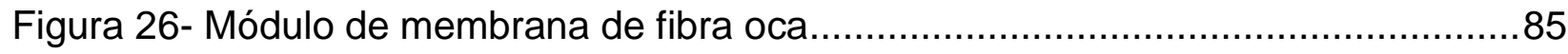

Figura 27- Local de instalação da unidade piloto de membrana ..................................86

Figura 28- Fluxograma de processo da unidade piloto de membranas .........................87

Figura 29- Volume de permeado produzido em função do aumento da pressão ..........97

Figura 30- Volume de permeado produzido em função da frequência de retrolavagem

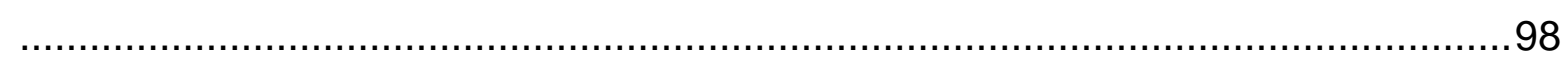

Figura 31- Variação da vazão de permeado em função do tempo de operação .............99

Figura 32- Variação da pressão na entrada da membrana em função do tempo de

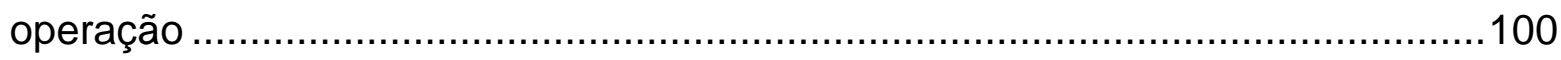

Figura 33- Eficiência do sistema em relação à remoção de contaminantes .................101 


\section{LISTA DE TABELAS}

Tabela 1 - Relação entre ICRH e DEA com o potencial de conflitos pelo uso da água . $<$ I

Tabela 2 - Tipos de reúso e aplicações

Tabela 3 - Padrões de qualidade da água de reúso - usos restritos e irrestritos nos

Estados Unidos .28

Tabela 4 - Diretrizes para reúso urbano não potável..

Tabela 5 - Classificação, parâmetros de qualidade e tratamento necessário, segundo

NBR- 13.969/97

Tabela 6- Limites recomendados para qualidade da água de resfriamento ( $\mathrm{mg} / \mathrm{l})$.

Tabela 7 - Agrupamento em classes de contaminantes que pode estar presentes nos

efluentes.

Tabela 8- Diferença entre os processos de separação por membranas e o de filtração convencional

Tabela 9- Comparações entre diferentes configurações de módulos ............................43

Tabela 10 Variação do diâmetro do poro das membranas de microfiltração ..................45

Tabela 11 - Variação do diâmetro do poro das membranas de Ultrafiltração .................46

Tabela 12 - Variação da taxa de fluxo em função do tipo de membrana.......................49

Tabela 13 - Materiais que conferem hidrofilicidade ou hidrofobicidade à membrana ....52

Tabela 14 Características dos produtos utilizados na remoção de material específico .69

Tabela 15 - Comparação da eficiência do sistema de ultrafiltração operando com

efluente distintos

Tabela 16 - Comparação da eficiência do sistema de ultrafiltração operando com

efluente distintos

Tabela 17 - Qualidade do permeado produzido a partir de esgoto bruto e primário......76

Tabela 18 - Qualidade dos efluentes produzidos pelos dois sistemas ..........................77

Tabela 19: Qualidade do efluente produzido pelo sistema MBR e ultrafiltração terciária.

78

Tabela 20 - Qualidade do Efluente e do Afluente do Sistema de tratamento .................79

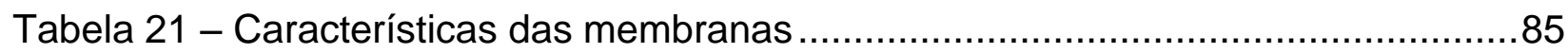

Tabela 22 - Consumo de água não potável no AISP ................................................94 
Tabela 23 - Qualidade do efluente tratado .95

Tabela 24 - Valores médio, mínimo e máximo dos resultados relativos às análises de água bruta e permeado.... 102

Tabela 25 - Comparação entre a qualidade da água produzida pelo sistema de ultrafiltração e aquela exigida pelos usos urbanos. 106

Tabela 26 - Comparação entre a qualidade da água produzida pelo sistema de ultrafiltração e aquela exigida para reposição em sistemas de resfriamento 107 


\section{SUMÁRIO}

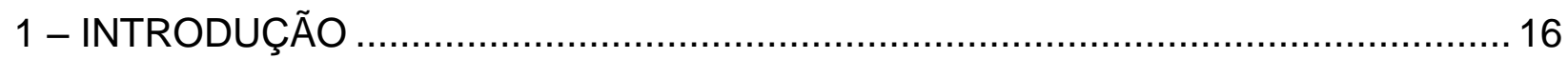

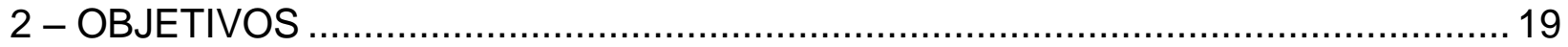

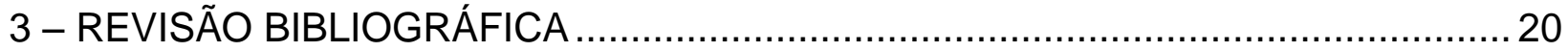

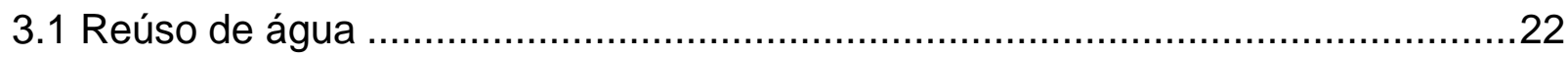

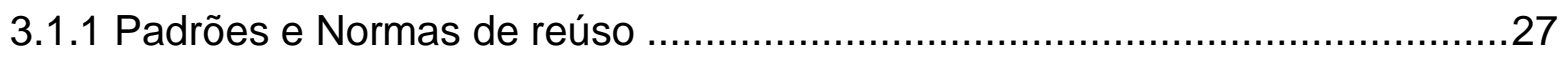

3.2 Tratamento biológico por processo de Lodos ativados .....................................33

3.3 Tecnologia de Separação por Membranas ……...............................................34

3.3.1 Princípios Básicos da Tecnologia de Separação por Membranas ..................37

3.3.2 Classificação dos processos de separação por membranas .........................43

3.3.3 Características das Membranas ............................................................ 48

3.3.4 Características Operacionais do Sistema e o Desempenho da Membrana .52 3.3.5 Interferências dos contaminantes no desempenho das membranas .............55

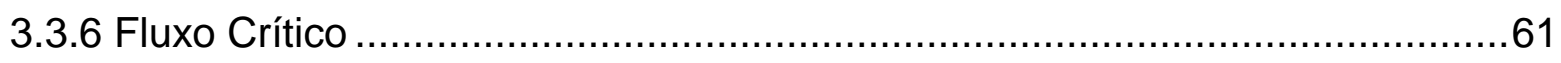

A partir da interpretação do gráfico é possível afirmar que estabelecer pressões de operação elevadas não significa aumentar a produtividade do sistema. ................63

3.3.7 Projetos de sistemas de separação por membranas ...................................63

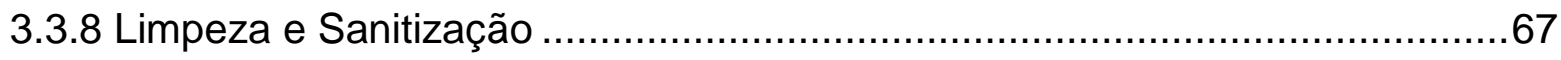

3.3.9 Processos de Separação por Membranas utilizados na produção de água

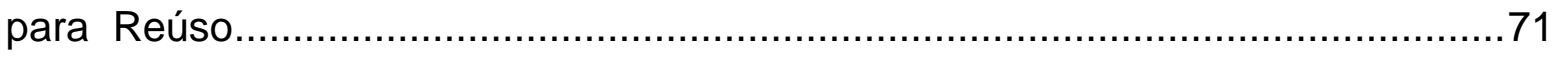

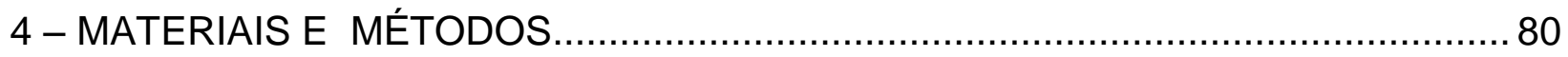

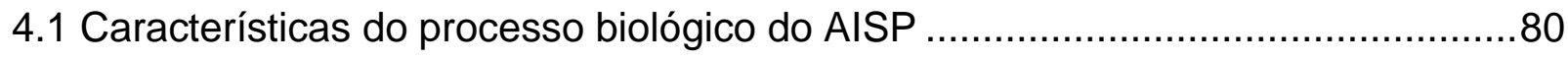

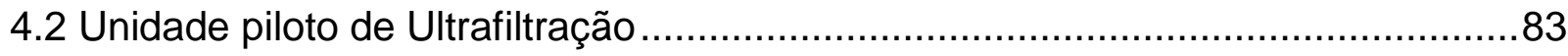

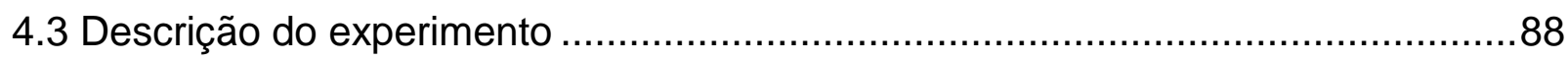

4.4 Metodologia utilizada para o desenvolvimento da pesquisa ..............................91 
4.4.1 Identificação dos usos preponderantes de água no Aeroporto Internacional de São Paulo.

4.4.2 Caracterização do efluente gerado no AISP

4.4.3 Estabelecimento das características da água de reúso 91

4.4.4 Caracterização qualitativa da água produzida pelo sistema 92

4.4.5 Definição de parâmetros operacionais ………….....................................92

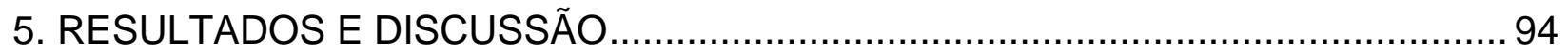

5.1 Avaliação da demanda de água no AISP .........................................................94

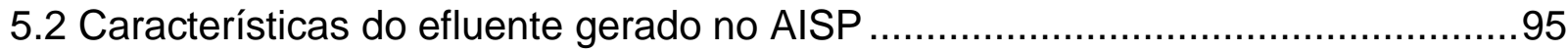

5.3 Estabelecimento da pressão de operação .......................................................97

5.5 Estabelecimento da frequência de retrolavagem ...........................................98

5.6 Eficiência do sistema em relação à produção de água tratada..............................99

5.7 Estabelecimento da frequência de limpeza química ..........................................99

5.3 Eficiência do sistema em relação à remoção de contaminantes .........................101

6 - CONCLUSÕES E CONSIDERAÇÕES FINAIS ............................................. 108

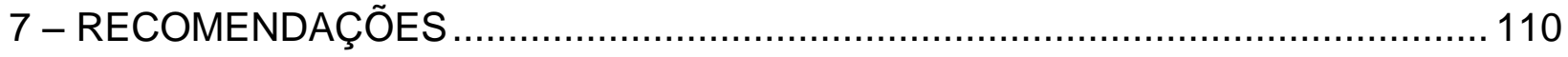

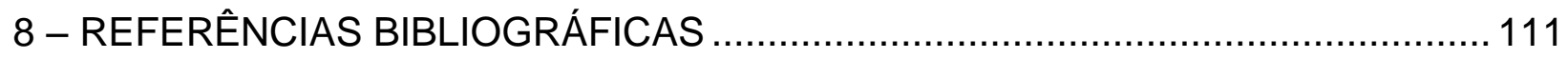

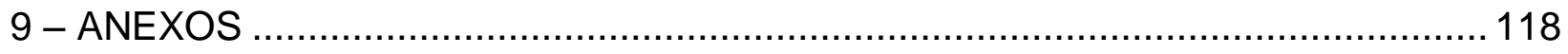

Anexo 1 - Catálogo da membrana utilizada no experimento ...............................118 


\section{1 - INTRODUÇÃO}

Sabe-se que a água é, de longe, a substância mais frequente na superfície do planeıa, já que $70 \%$ é coberta por ela. Participa sempre com mais de $65 \%$ da massa corpórea dos indivíduos vivos, onde atua em todos os fenômenos biológicos e reações bioquímicas desde o início da cadeia alimentar (fotossíntese).

No entanto apenas 2,5\% dessa massa líquida são de água doce. E mais ainda, apenas 0,3\% dela compõem mananciais acessíveis ao atendimento das necessidades socioeconômicas humanas e dos ecossistemas (REBOUÇAS, 2006).

Esses percentuais só começaram a preocupar a partir do fim do terceiro quartil do Século XX, em decorrência de profundas mudanças socioeconômicas iniciadas a partir da segunda metade do mesmo século, as quais expandiram a consciência da limitação dos recursos naturais.

Já em 1958 o Conselho Econômico e Social da ONU apontava para a gestão adequada dos recursos hídricos introduzindo o conceito de substituição de fontes, a partir do seguinte princípio (UNITED NATIONS, 1958 apud. HESPANHOL, 2002):

"a não ser que exista grande disponibilidade nenhuma água de boa qualidade deve ser utilizada para usos que toleram águas de qualidade inferior".

O Brasil detém, aproximadamente, $12 \%$ das reservas de água doce de superfície (REBOUÇAS, 2006), embora abrigue menos de $2,75 \%$ da população mundial, (adaptado de IBGE e UNFPA, 2010), números que isolados podem conduzir a avaliações equivocadas, pois se deve levar em conta um fator adverso presente também em outras regiões do planeta: a distribuição das reservas não uniforme em razão das características climáticas regionais (a caatinga e o semi-árido nordestino e áreas que sofrem desertificação progressiva, no Sul, são exemplos), bem como a distribuição da população.

A concentração da população em grandes centros urbanos agrava o problema de escassez de recursos hídricos, fato que pode ser observado na região metropolitana de São Paulo, onde além das demandas residenciais e industriais, as relativas ao abastecimento de locais públicos como hospitais, aeroportos, parques, escolas, clubes, entre outros, também são representativas. 
Das demandas mencionadas, o uso da água em sistemas aeroportuários merece especial destaque pelo fato deste tipo de empreendimento atender um grande número de usuários diariamente e, com isso, apresentar elevada demanda de água. $O$ Aeroporto Internacional de São Paulo (AISP), onde foi desenvolvida a pesquisa em questão, está localizado em uma região densamente povoada e com reduzida disponibilidade hídrica. Nesse contexto, entre outros benefícios, adotar fontes alternativas de água poupa mananciais para consumo humano, além de reduzir os custos associados ao consumo de água proveniente de fontes convencionais.

A construção de um terceiro terminal no AISP, atualmente em fase avançada de projeto, ampliará em $70 \%$ sua capacidade no transporte de cargas e passageiros, fato que aumentará significativamente a demanda de água. Sendo assim, torna-se urgente a adoção de medidas que reduzam o consumo de água proveniente de fontes convencionais.

Nesse contexto, adotar esgoto tratado como fonte para atendimento às demandas dos usos não potáveis pode ser uma opção que contribui de forma significativa à preservação dos recursos hídricos. Diversos exemplos de aplicação da prática do reúso a partir de esgoto tratado podem ser citados: no Japão o esgoto tratado é utilizado em processos industriais (FUNAMIZU; ONITSUKA; HATORI, 2008); no interior de São Paulo, um parque aquático utiliza esgoto tratado para suprir a demanda dos usos não potáveis existentes no local (MANCUSO, 2003); no estado da Califórnia essa prática foi adotada para irrigação de áreas verdes; um aeroporto na China utiliza esgoto tratado para atender às demandas dos sanitários, lavagem de veículos, irrigação de áreas verdes e limpeza de vias (ASANO, 1998)

Porém, essa prática deve ser adotada com muito critério, tratando o efluente de forma adequada para minimizar os riscos à saúde dos usuários e aos equipamentos nos quais a água dessa fonte pode ser utilizada.

Atualmente, dentre as tecnologias destinadas ao tratamento de efluentes, os sistemas de separação por membranas vêm se destacando em relação aos processos convencionais, devido a fatores como: elevada eficiência em relação à remoção de contaminantes, áreas reduzidas para instalação do sistema, facilidade de operação e por prescindir do uso de produtos químicos, na fase de tratamento, produzindo água 
com qualidade comparativamente superior (SCHNEIDER E TSUTYA, 2001). Um exemplo recente de aplicação dessa tecnologia é o projeto Aquapolo que tem como objetivo produzir água de reúso para fins industriais, apartir de esgoto secundário, destinada ao abastecimento do pólo petroquímico de Capuava localizado na região do ABC paulista (PROJETO AQUAPOLO, 2011). Além do ganho ambiental, esse projeto proporcionará um aumento na oferta de água tratada à população da Grande São Paulo, pois com ele o Polo Petroquímico deixa de captar água de fontes convencionais, economizando mensalmente um volume de 1,684 bilhão de litros de água que podem ser destinados ao consumo humano. 


\section{2-OBJETIVOS}

O objetivo desta pesquisa foi avaliar a viabilidade técnica de aplicação de um sistema de ultrafiltração tangencial para tratamento complementar do efluente proveniente de um sistema composto por lagoas aeradas, visando à implantação da prática do reúso de água em sistemas aeroportuários.

Os objetivos específicos deste trabalho foram:

$\checkmark$ Estabelecer parâmetros operacionais para o sistema de ultrafiltração, através de ensaios específicos;

$\checkmark$ Avaliar a eficiência do sistema em relação à remoção de contaminantes relevantes para a adoção da prática do reúso;

$\checkmark$ Identificar as possíveis atividades com potencial para uso da água produzida pelo sistema. 


\section{3 - REVISÃO BIBLIOGRÁFICA}

A escassez de água em regiões metropolitanas como a de São Paulo (RMSP), entre outras, não tem origem no clima ou na capacidade de armagenagem em reservatórios, mas na ação antrópica traduzida pela expansão populacional desordenada que, além de apresentar uma demanda elevada de água, contribui com a poluição dos corpos hídricos, faltando uma firme gestão que integre preservação de recursos hídricos e uso e ocupação do solo para inibir o consumo excessivo de água e a degradação da qualidade dos mananciais.

Atualmente, a demanda de água na RMSP é de, aproximadamente, $189 \mathrm{~m}^{3}$.hab ${ }^{-1}$.ano ${ }^{-1}$, cerca de $40 \%$ superior à disponibilidade natural da região (DAEE, 2012). Para suprir 0 déficite relativo ao percentual apresentado o poder público promove a adução de água das bacias dos rios Jundiaí e Piracicaba. De acordo com Hespanhol (2008), resolver o problema de escassez de água de uma região buscando esse recurso nas bacias circunvizinhas, além de obsoleta, é uma prática inaceitável dos pontos de vista econômico, ambiental e de gestão de recursos hídricos. O ato de suprir a demanda de água em determinada região em detrimento de outra, potencializa os conflitos entre os usuários dos recursos hídricos, sendo que a redução na disponibilidade de água pode comprometer o desenvolvimento sócio-econômico da população. Além disso, essa pratica contribui com o aumento da poluição hídrica na bacia, tendo em vista que o esgoto gerado, a partir da água aduzida, é lançado nos corpos hídricos da própria bacia, contribuindo, inclusive, com o comprometimento dos mananciais, fato que agrava os problemas associados à escassez desse recurso.

De acordo com o mesmo autor, estima-se que $43 \%$ da água consumida na região destina-se ao suprimento dos usos potáveis e os $57 \%$ restantes referem-se aos usos não potáveis, os quais poderiam ser atendidos com água de reúso (HESPANHOL, 2008), caso a gestão de recursos hídricos fosse pautada na qualidade e não na quantidade de água.

De acordo com Mierzwa (2002), o potencial de ocorrência de conflitos pode ser medido pelo Índice de Comprometimento de Recursos Hídricos (ICRH) e pela Disponibilidade Específica de Água (DEA), conforme ilustram a tabela 1 e o gráfico da figura 1. 
Tabela 1 - Relação entre ICRH e DEA com o potencial de conflitos pelo uso da água

\begin{tabular}{lll}
\hline ICRH & DEA $\left(\mathbf{m}^{3} /\right.$ ano.hab.) & \multicolumn{1}{c}{ Potencial de Conflito } \\
\hline 1 & DEA $\geq 10.000$ & $\begin{array}{l}\text { Quantidade suficiente de água para atendimento das } \\
\text { necessidades humanas e ambientais }\end{array}$ \\
2 & $10.000>\mathrm{DEA}>2.000$ & $\begin{array}{l}\text { Pequenas disputas pelo uso da água, processos isolados de } \\
\text { poluição } \\
\text { Comprometimento da capacidade de autodepuração dos } \\
\text { corpos d'água e conflitos pelo uso da água }\end{array}$ \\
4 & $2.000>\mathrm{DEA}>1.000$ & $\begin{array}{l}\text { Potencial de ocorrência de graves problemas ambientais e } \\
\text { intensificação dos conflitos pelo uso da água }\end{array}$ \\
5 & DEA < 500 & Condições críticas com relação à disponibilidade de água
\end{tabular}

Fonte: Mierzwa e Hespanhol 2005

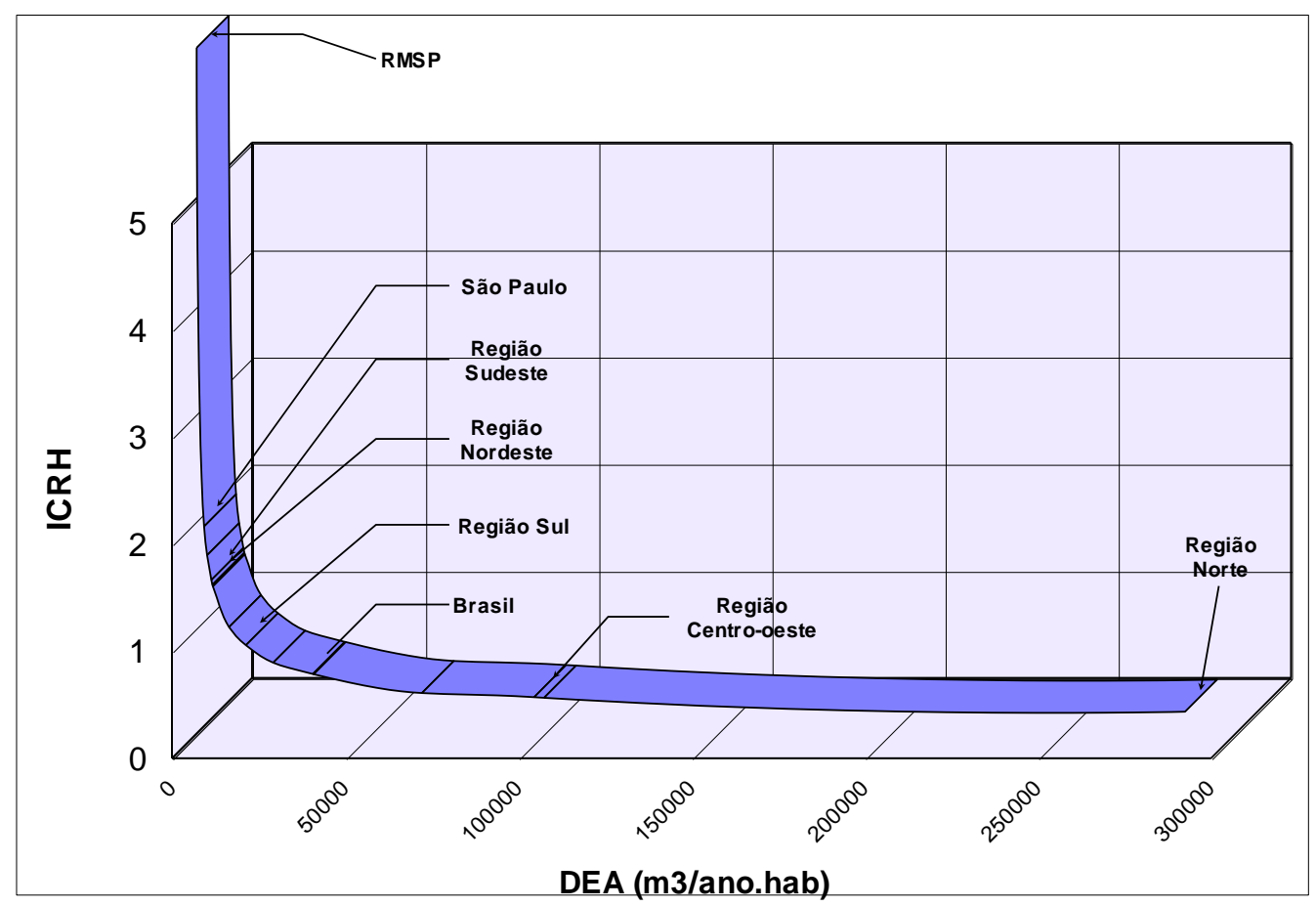

Figura 1- Potencial de conflitos gerados pelo uso da água nas principais regiões brasileiras, inclusive a Região Metropolitana de São Paulo

Fonte: MIERZWA e HESPANHOL, 2005

Observando-se a tabela 1 e o gráfico da figura 1 é possível concluir que a escassez de água deixou de ser um problema exclusivo de regiões de clima árido ou semiárido, atingindo também locais onde não há predomínio desses climas, mas que são densamente povoados. 
A melhor compreensão da problemática associada à água tem subsidiado decisões que contemplam os preceitos da sustentabilidade, onde a racionalização do uso e o reúso aparecem como estratégias de grande importância, pois proporcionam a preservação da água de boa qualidade.

\subsection{Reúso de água}

Segundo Westerhoff (1984) apud Filho e Mancuso (2003), o reúso pode ser classificado em duas grandes categorias: potável e não potável. Dentro dessas categorias o reúso pode ser direto, quando o esgoto, tratado ou não, é diretamente aplicado ao uso pretendido. Já no caso do esgoto tratado ser lançado em corpos hídricos, superficiais ou subterrâneos, onde são submetidos à diluição e purificação natural e posteriormente utilizados, tem-se o reúso indireto.

A tabela 2 apresenta, de forma sucinta, os tipos de reúso e suas respectivas aplicações.

Tabela 2 - Tipos de reúso e aplicações

\begin{tabular}{|c|c|c|}
\hline \multicolumn{2}{|c|}{ TIPOS DE REÚSO } & APLICAÇÕES \\
\hline & Potável & Consumo humano \\
\hline Direto & & Industriais* \\
\hline ou & & $\begin{array}{l}\text { Agrícolas } \\
\text { Urbanas }\end{array}$ \\
\hline Indireto & Não Potável & $\begin{array}{c}\text { Recreacionais } \\
\text { Domésticas } \\
\text { Recarga de aquífero } \\
\text { Paisagísticas }\end{array}$ \\
\hline
\end{tabular}

De modo geral o reúso será implantado de forma adequada caso haja compatibilidade entre as características do efluente e os requisitos de qualidade da água exigida pelos 
diversos usos. Essa prática, desde que adotada de forma criteriosa, é uma ferramenta indispensável ao processo de gestão de recursos hídricos, tendo em vista o crescimento sem precedentes da demanada de água ao redor do mundo (ASANO, 1998). Contudo, cabe ressaltar que essa prática não deve se sobrepor àquelas relacionadas à racionalização do uso da água como, redução de perdas, utilização de equipamentos economizadores, alteração de procedimentos e processos, além da conscientização do usuário - medias que promovem a redução da demanda de água e do volume de efluente gerado. Essas medidas devem ser priorizadas seja qual for a atividade na qual a água é empregada (MIERZWA e HESPANHOL, 2005).

Segundo (PHILIPPI, 2003), todo efluente gerado deve ser minimizado, tratado e reintegrado para nova utilização. Essa prática proporciona a preservação de mananciais destinados ao abastecimento público, à proteção ambiental e vantagens econômicas, pois se baseia no uso de efluentes, tratados ou não, para fins que não necessitem de água com padrão de qualidade elevado.

No diagrama de figura 2 estão apresentadas as principais etapas para a implantação de programas de conservação e reúso de água, onde a metodologia empregada contempla ações destinadas à caracterização das atividades e dos processos que consomem água e geram efluentes. 


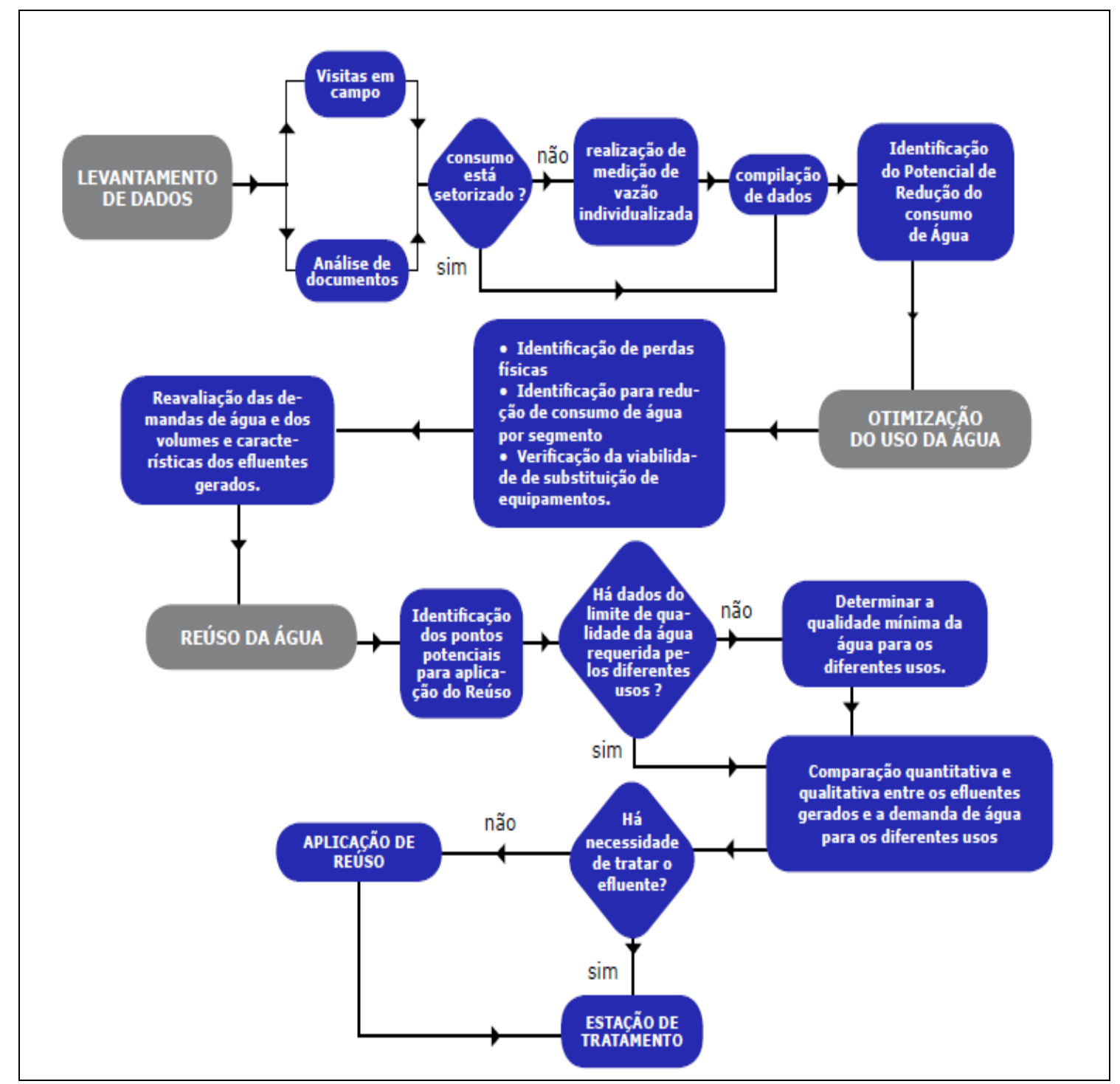

Figura 2 - Diagrama para desenvolvimento de um plano de conservação e reúso de água (FIRJAN, 2006)

Nas etapas relativas ao desenvolvimento de um programa de conservação e reúso da água são contemplados aspectos quantitativos e qualitativos desse recurso, além da priorização de ações relacionadas à racionalização do uso da água, conforme mostra o diagrama apresentado na figura 2.

Há diversas fontes de água que podem ser utilizadas em um programa de reúso, dentre elas o esgoto sanitário que, em muitas regiões, é a fonte de água mais segura em termos quantitativos, pois é um dos poucos recursos hídricos que não sofrem alterações sazonais significativas. Essa é uma realidade na região do MENA (Oriente 
Médio e Norte da África), onde há apenas $1 \%$ do estoque de água renovável do planeta. Nessa região a utilização de esgoto tratado é uma prática amplamente utilizada, pois a água naturalmente disponível não supre a demanda de, aproximadamente, 300 milhões de pessoas (SANTOS e MANCUSO, 2003).

No Japão a utilização de águas residuárias destinada ao abastecimento industrial, foi adotada pela primeira vez em 1955, para reduzir o impacto do consumo sobre as reservas de água subterrânea da cidade de Tókio (FUNAMIZU; ONITSUKA; HATORI, 2008).

Em 1981, na Califórnia, foi construído um campo de golfe, em um empreendimento residencial, onde se fez necessário utilizar o esgoto tratado para suprir a demanda relativa à irrigação, pois não havia disponibilidade hídrica de fontes superficiais nem subterrâneas (ASANO et. al., 2007).

No Brasil, um parque temático adotou a prática do reúso não potável a partir de esgoto tratado por processo biológico seguido de sistema de membrana de fibra oca e desinfecção (MANCUSO E SANTOS, 2003). A água de reúso é utilizada para atender às demandas de descarga sanitárias e irrigação das áreas verdes do parque.

Mais especificamente na regiaõ metropolitana de São Paulo, um exemplo recente de reúso refere-se ao Projeto Aquapolo, o qual representa o maior empreendimento destinado à geração de água de reúso no hemisfério sul, com capacidade para produzir até $1 \mathrm{~m} / \mathrm{s}$. Esse projeto prevê a utilização do esgoto secundário gerado na região do ABC paulista para suprir a demanda dos usos industriais no Polo Petroquímico de Mauá (PROJETO AQUAPOLO, 2011).

Antes do Aquapolo

Um fator relevante que atualmente tem sido ressaltado por diversos autores é a importância do reúso descentralizado, o qual é definido como sistema local de coleta, tratamento e disposição/reúso de esgotos gerados em casas, condôminos, indústrias ou unidades institucionais (TCHOBANOGLUOUS, 1995 apud ASANO, 1998). Muitas vezes a infra-estrutura necessária à instalação de um sistema centralizado requer altos investimentos, principalmente em relação ao sistema de distribuição, que deve ser composto por adutoras de grandes extensões 
Um exemplo de reúso descentralizado pode ser observado em um estudo desenvolvido para um condomínio residencial fechado, localizado na cidade de Santana do Parnaíba, região periférica de São Paulo. No caso, optou-se pelo uso de esgoto tratado para atender às demandas dos usos não potáveis, para que o empreendimento tivesse sua aprovação junto ao órgão competente, pois as condições hídricas do entorno não permitiriam a instalação de um loteamento como o proposto (SOUZA, 2008).

Outro exemplo de reúso descentralizado é aquele implantado em sistemas aeroportuários, a partir do esgoto gerado no local, onde a adoção de um programa de gestão de recursos hídricos é de extrema importância, tendo em vista que grande parte dos aeroportos apresenta demanda de água semelhante à de cidades de pequeno porte, por atenderem diariamente um número elevado de pessoas, entre elas funcionários, passageiros e visitantes. Nesse tipo de empreendimento o potencial para implantação da prática do reúso é significativamente elevado tendo em vista a grande demanada por água não potável, representada pelos usos preponderantes que são: descargas em bacias sanitárias mictórios e sistemas de resfriamento, irrigação de áreas verdes e lavagem de pistas e de aeronaves (OKPALA, 2005)

Utilizar esgoto sanitário para suprir a demanda dos usos não potáveis, existentes em aeroportos, pode ser uma alternativa às fontes convencionais de abastecimento. Porém, essa prática requer cautela, principalmente no que se refere à saúde dos usuários e trabalhadores, devido ao elevado potencial da presença de organismos patogênicos, advindo de diversas regiões do mundo. Sendo assim é de fundamental importância a adoção de um sistema de tratamento adequado.

$\mathrm{Na}$ China, o aeroporto internacional de Beijing utiliza o esgoto urbano, tratado a partir de membranas de ultrafiltração, como fonte de água para atender aos seguintes usos não potáveis: descarga em sanitários, lavagem de veículos, irrigação de áreas verdes e limpeza de vias (ASANO, 1998).

É importante ressaltar que a prática do reúso torna-se mais viável quando prevista na fase de projeto dos empreendimentos, pois é possível a previsão, já na fase de projeto, da infraestrutura necessária à implantação dessa prática. 


\subsubsection{Padrões e Normas de reúso}

Frente à grande importância que a água representa para a humanidade é fundamental a criação de normas e padrões que propiciem seu uso de racional, o que contribui com o uso sustentável desse recurso natural.

De acordo com Hespanhol (1994), para que a implatação da prática do reúso seja eficiente é de suma importância o estabelecimento de padrões e normas embasados em características locais como questões climáticas, culturais, políticas e sociais. Além disso, essas diretrizes devem estar fundamentadas em resultados de pesquisas científicas e dados epidemiológicos.

Esses padrões e normas, associados aos dados de qualidade do efluente disponível, permitem definir a estratégia de tratamento mais adequada para possibilitar a obtenção da água de reúso (HESPANHOL, 2008).

Segundo EPA (2004), com o objetivo de obter o máximo benefício com a prática do reúso, protegendo o ambiente e a saúde pública, estados como Arizona, Califórnia, Colorado, Florida, Georgia, Hawaii, Massachusetts, Nevada, New Jersey, New Mexico, Carolina do Norte, Ohio, Oregon, Texas, Utah, Washington e Wyoming, nos Estados Unidos, desenvolveram regulamentos ou orientações que incentivam a reutilização de água como uma estratégia de conservação dos recursos hídricos. Neles estão especificados os requisitos de qualidade da água, os processos de tratamento, ou ambos, para todo o espectro de aplicações do reúso. Outros estados têm desenvolvido regulamentações com a intenção de proporcionar uma alternativa à descarga de esgoto em águas de superfície, sem considerar a água recuperada como fonte alternativa.

As diretrizes para reúso urbano podem ser direcionadas aos usos irrestritos, os quais envolvem exposição humana e, sendo assim exigem níveis de tratamento mais elevados quando comparados às exigências dos usos restritos, onde a exposição humana é controlada. A tabela 3

apresenta a qualidade da água de reúso urbano restrito e irrestrito adotada por sete estados Norte Americanos, além dos tipos de tratamentos a serem utilizados para obter água com qualidade desejada. 
Tabela 3 - Padrões de qualidade da água de reúso - usos restritos e irrestritos nos Estados Unidos

\begin{tabular}{|c|c|c|c|c|c|c|c|}
\hline & Arizona & Califórnia & Flórida & Hawaí & Nevada & Texas & Washington \\
\hline \multicolumn{8}{|c|}{ USOS RESTRITOS } \\
\hline Tratamento & $\begin{array}{c}\text { Tratamento } \\
\text { Secundário } \\
e \\
\text { Desinfecção }\end{array}$ & $\begin{array}{l}\text { Tratamento } \\
\text { Secundário, } \\
\text { Oxidação e } \\
\text { Desinfecção }\end{array}$ & $\begin{array}{l}\text { Tratamento } \\
\text { Secundário, } \\
\text { Filtração e } \\
\text { alto nível de } \\
\text { Desinfeccão }\end{array}$ & $\begin{array}{l}\text { Oxidação e } \\
\text { desinfecção }\end{array}$ & $\begin{array}{c}\text { Tratamento } \\
\text { Secundário } \\
e \\
\text { Desinfecção }\end{array}$ & NE & $\begin{array}{l}\text { Oxidação e } \\
\text { desinfeç̧ão }\end{array}$ \\
\hline $\mathrm{DBO}_{5}(\mathrm{mg} / \mathrm{l})$ & $\mathrm{NE}^{(\mathrm{a})}$ & NE & 20 & NE & 30 & 20 & 30 \\
\hline SST (mg/l) & $N E$ & NE & 5 & NE & $\mathrm{NE}$ & NE & 30 \\
\hline $\begin{array}{c}\text { Turbidez } \\
\text { (NTU) }\end{array}$ & NE & NE & NE & 2 (Max) & NE & 3 & $\begin{array}{l}2 \text { (med) } \\
5 \text { (max) }\end{array}$ \\
\hline \multirow{3}{*}{$\begin{array}{c}\text { Coliformes } \\
\text { (em 100ml) } \\
\text { (valores } \\
\text { médios e } \\
\text { máximos) }\end{array}$} & Fecal & Total & $\mathrm{NE}$ & Fecal & Fecal & Fecal & Total \\
\hline & 200 & 23 & $\begin{array}{c}\text { Não } \\
\text { detectável } \\
\text { em } 75 \% \text { das } \\
\text { amostras }\end{array}$ & 23 & 23 & 200 & 23 \\
\hline & 800 & $\begin{array}{c}240 \\
\text { (em } 30 \text { dias) }\end{array}$ & 25 & 200 & 240 & 800 & 240 \\
\hline
\end{tabular}

USOS IRRESTRITOS

\begin{tabular}{|c|c|c|c|c|c|c|c|}
\hline Tratamento & $\begin{array}{c}\text { Tratamento } \\
\text { Secundário } \\
e \\
\text { Desinfecção }\end{array}$ & $\begin{array}{c}\text { Oxidação, } \\
\text { Coagulação, } \\
\text { Filtração e } \\
\text { Desinfecção }\end{array}$ & $\begin{array}{l}\text { Tratamento } \\
\text { Secundário, } \\
\text { Filtração e } \\
\text { alto nível de } \\
\text { Desinfecção }\end{array}$ & $\begin{array}{l}\text { Oxidação, } \\
\text { filtração e } \\
\text { desinfecção }\end{array}$ & $\begin{array}{c}\text { Tratamento } \\
\text { Secundário } \\
e \\
\text { Desinfecção }\end{array}$ & NE & $\begin{array}{c}\text { Oxidação, } \\
\text { Coagulação, } \\
\text { Filtração e } \\
\text { Desinfecção }\end{array}$ \\
\hline $\mathrm{DBO}_{5}(\mathrm{mg} / \mathrm{l})$ & NE & NE & 20 & NE & 30 & 5 & 30 \\
\hline SST (mg/l) & $\mathrm{NE}$ & $\mathrm{NE}$ & 5 & NE & NE & $\mathrm{NE}$ & 30 \\
\hline \multirow{2}{*}{$\begin{array}{l}\text { Turbidez } \\
\text { (NTU) }\end{array}$} & 2 (med) & 2 (med) & \multirow{2}{*}{ NE } & \multirow{2}{*}{2} & \multirow{2}{*}{ NE } & \multirow{2}{*}{3} & 2 (med) \\
\hline & 5 (max) & $5(\max )$ & & & & & $5(\max )$ \\
\hline \multirow{3}{*}{$\begin{array}{c}\text { Coliformes } \\
\text { (em 100ml) } \\
\text { (valores } \\
\text { médios e } \\
\text { máximos) }\end{array}$} & Fecal & Total & Fecal & Fecal & Fecal & Fecal & Total \\
\hline & $\begin{array}{c}\text { Não } \\
\text { detectável }\end{array}$ & $\begin{array}{c}\text { Não } \\
\text { detectável } \\
\text { em } 75 \% \text { das } \\
\text { amostras }\end{array}$ & 25 & 2,2 & 2,2 & 20 & 2,2 \\
\hline & 23 & 23 & 25 & 23 & 23 & 75 & 23 \\
\hline
\end{tabular}

(a) Não especificado pela regulamentação do estado

Tendo em vista o aumento da importância da prática do reúso no gerenciamento dos recursos hídricos, a EPA por meio da publicação do Guia para reúso de Água (EPA, 
2004), aborda vários aspectos relacionados ao reúso de água e recomenda limites de qualidade da água para diferentes usos, processos de tratamento e frequência de monitoramento, entre outros.

$\mathrm{Na}$ tabela 4 estão apresentadas as diretrizes para reúso urbano não potável a partir de esgoto municipal, conforme estabelecido pela EPA, 2004 apud ASANO.

Tabela 4 - Diretrizes para reúso urbano não potável

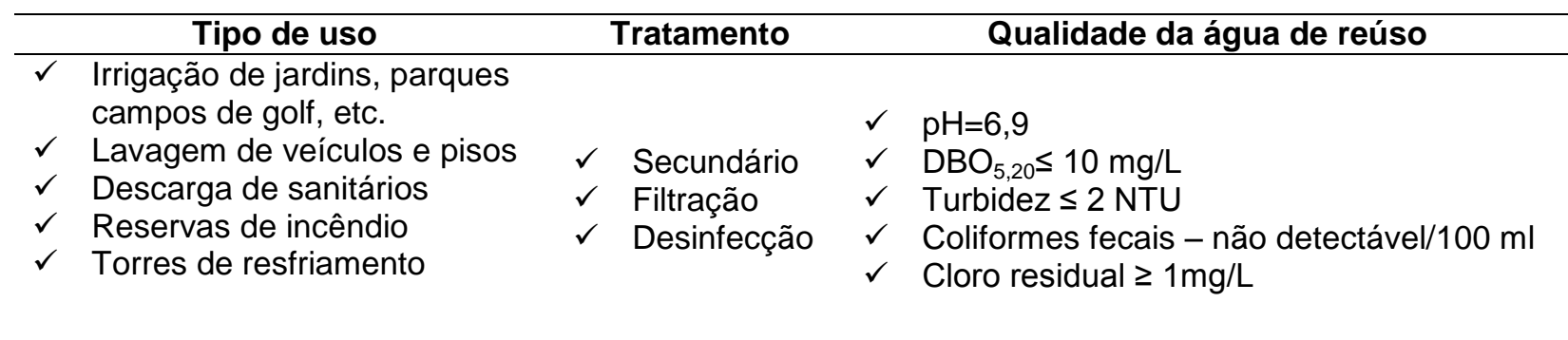

Fonte: Asano, 2007.

Atualmente no Brasil há uma política incipiente no que se refere às regulamentações destinadas à implantação das práticas relacionadas ao reúso e à racionalização do uso da água. Em nível federal existe a Resolução do Conselho Nacional de Recursos Hídricos CNRH o 54, de 28/11/2005 que "estabelece diretrizes gerais para a implantação da prática de reúso não potável de água.

Nas esferas estaduais e municipais vêm surgindo iniciativas, como a Lei 7663/91 que dispõe sobre a gestão integrada de recursos hídricos no estado de São Paulo e a Lei $N^{\circ}$ 14018/2005 do município de São Paulo que institui o Programa Municipal de Conservação e Uso Racional da Água em Edificações.

Apesar de não ter caráter legal, a norma técnica NBR 13969/1997 criada pela Associação Brasileira de Normas Técnicas - ABNT dispõe sobre o projeto, a construção e operação de tanques sépticos e prevê a utilização do efluente proveiente desse sistema para atendender à demanda dos usos que exijam qualidade de água não potável, mas sanitariamente segura, tais como, irrigação de jardins, lavagem de pisos e veículos automotivos, descarga de vasos sanitários, usos paisagísticos etc. Essa norma estabelece: planejamento do sistema de reúso, usos previstos para o esgoto tratado, volume de esgoto a ser reutilizado, grau de tratamento necessário, sistema de 
reservação e distribuição e manual de operação e treinamento dos responsáveis. Ela ainda define classes de reúso de acordo com o uso pretendido:

$\checkmark$ Classe1: lavagem de veículos e outros usos onde há potencial de aspiração de aerossóis devido ao contato direto do usuário com a água de reúso;

$\checkmark$ Classe 2: lavagens de pisos, calçadas e irrigação de jardins, manutenção de lagos e canais para fins paisagísticos, exceto chafarizes;

$\checkmark$ Classe 3: reúso nas descargas de vasos sanitários;

$\checkmark$ Classe 4: reúso nos pomares, cereais, forragens, pastagens para gados e outros cultivos através de escoamento superficial ou por sistema de irrigação pontual.

A tabela 5 apresenta os parâmetros de qualidade da água de reúso e o tratamento necessário, para cada uma das classes conforme estabelecido na NBR 13.969/97

Tabela 5 - Classificação, parâmetros de qualidade e tratamento necessário, segundo NBR- 13.969/97

\begin{tabular}{lccccc}
\hline \multicolumn{1}{c}{ Parâmetros } & \multirow{2}{*}{ Und } & \multicolumn{4}{c}{ NBR 13969 } \\
\cline { 3 - 6 } Coliformes Fecais & $(\mathrm{NMP} / 100 \mathrm{ml})$ & $<200$ & $<500$ & $<500$ & $<500$ \\
\cline { 3 - 5 } $\mathrm{pH}$ & - & $6-8$ & - & - & - \\
Turbidez & $(\mathrm{UT})$ & $<5$ & $<5$ & $<10$ & - \\
Cloro residual & $(\mathrm{mg} \mathrm{Cl} / \mathrm{L})$ & $0,5-1,5$ & $>0,5$ & - & - \\
Sólidos & $(\mathrm{mg} / \mathrm{L})$ & $<200$ & - & - & - \\
Dissolvidos Totais & & & & & \\
\hline
\end{tabular}


Tabela 6 (continuação) - Classificação, parâmetros de qualidade e tratamento necessário, segundo NBR-13.969/97

\begin{tabular}{|c|c|c|c|c|}
\hline $\begin{array}{l}\text { Oxigênio } \\
\text { Dissolvido }\end{array}$ & - & - & - & $>2,0$ \\
\hline Tratamentos necessários & $\begin{array}{c}\text { Aeróbios } \\
\text { (filtro } \\
\text { aeróbio } \\
\text { submerso } \\
\text { ou LAB* } \\
+ \\
\text { Filtração } \\
+ \\
\text { Cloração } \\
\end{array}$ & $\begin{array}{c}\text { Aeróbios } \\
\text { (filtro } \\
\text { aeróbio } \\
\text { submerso } \\
\text { ou LAB) + } \\
\text { Filtração + } \\
\text { Desinfecçã } \\
\text { o } \\
\end{array}$ & $\begin{array}{c}\text { Aeróbios } \\
\text { (filtro aeróbio } \\
\text { submerso ou } \\
\text { LAB) + } \\
\text { Filtração + } \\
\text { Desinfecção }\end{array}$ & $\begin{array}{c}\text { A aplicação } \\
\text { deve ser } \\
\text { interrompida } \\
\text { dez dias } \\
\text { antes da } \\
\text { colheita }\end{array}$ \\
\hline
\end{tabular}

Fonte: adaptado de ABNT - NBR 13.969 de setembro de 1997 apud SOUZA, 2007

*Lodos ativados biologicamente

Muitas aplicações exigem que um número maior de parâmetros referentes à qualidade da água sejam monitorados, comparativamente àqueles apresentados nas tabelas 3, 4 e 5. Um exemplo disso é a qualidade da água para torres de resfriamento, cujos parâmetros estão apresentados na tabela 6 .

Tabela 7- Limites recomendados para qualidade da água de resfriamento (mg/l)

\begin{tabular}{lc}
\multicolumn{1}{c}{ Parâmetros } & Valores Limites \\
\hline Cloretos & $500^{* *}$ \\
Sólidos Dissolvidos Totais & 500 \\
Dureza & 650 \\
Alcalinidade & 350 \\
pH & 6,9 a 9,0 \\
DQO & 75 \\
Sólidos Suspensos Totais & 100 \\
Turbidez & 50 \\
DBO & 25 \\
Compostos Orgânicos ${ }^{++}$ & 1,0 \\
Nitrogênio Amoniacal & 1,0 \\
Fosfato & 4,0 \\
Sílica & 50 \\
Alumínio & 0,1 \\
\hline
\end{tabular}


Tabela 8 (continuação) - Limites recomendados para qualidade da água de resfriamento $(\mathrm{mg} / \mathrm{l})$

\begin{tabular}{lc}
\hline Ferro & 0,5 \\
Manganês & 0,5 \\
Cálcio & 50 \\
Magnésio & 0,5 \\
Bicarbonato & 24 \\
Sulfato & 200
\end{tabular}

${ }^{* *}$ Em alguns tipos de sistema essa concentração deve ser menor ++ Substâncias sensíveis ao azul de metileno

Fonte: adaptado de Crook, 1996 apud Mierzwa Hespanhol, 2005.

Atualmente no Brasil, toda a água proveniente de mananciais de abastecimento é tratada para atingir níveis potáveis. Entretanto, conforme EPA (2004), em grandes centros urbanos apenas $28 \%$ da demanda é relativa a usos que exigem essa qualidade. Para adequar a qualidade das águas residuárias aos padrões exigidos pelos usos pretendidos, é necessário conhecer os contaminantes presentes no efluente para que se possa adotar a tecnologia de tratamento mais adequada.

Segundo Parekh (1998) apud Mierzwa e Hespanhol (2005), há seis classes de contaminantes que podem estar presentes em um efluente, conforme mostra a tabela 7 .

Tabela 9 - Agrupamento em classes de contaminantes que pode estar presentes nos efluentes

\begin{tabular}{|c|c|c|}
\hline Classe & Contaminante & Exemplo \\
\hline 1 & Sais inorgânicos dissolvidos & $\begin{array}{c}\text { Íons metálicos e não metálicos } \\
\left(\mathrm{Cl}^{-}, \mathrm{F}^{-}, \mathrm{SO}_{4}^{2-}, \mathrm{NO}_{3}{ }^{-}, \mathrm{Ca}^{2+}, \mathrm{Cr}^{6+}\right. \\
\mathrm{Na}^{+}, \mathrm{K}^{+}, \mathrm{Mg}^{2+}, \mathrm{CN}^{-}, \mathrm{HCO}^{3-}, \mathrm{NH}_{4}^{+} \\
\text {etc. })\end{array}$ \\
\hline 2 & Gases dissolvidos & $\mathrm{NH}_{3}, \mathrm{H}_{2} \mathrm{~S}$ \\
\hline 3 & Compostos orgânicos dissolvidos & $\begin{array}{c}\text { Solventes, pesticidas, herbicidas, } \\
\text { tensoativos e açúcares, entre } \\
\text { outros }\end{array}$ \\
\hline 4 & Partículas em suspensão & $\begin{array}{c}\text { Areia, Sílica coloidal, sais } \\
\text { insolúveis, sólidos suspensos } \\
\text { diversos }\end{array}$ \\
\hline 5 & Microorganismos & $\begin{array}{c}\text { Bactérias, vírus, protozoários, } \\
\text { fungos, leveduras }\end{array}$ \\
\hline 6 & Óleos e graxas & \\
\hline
\end{tabular}

Fonte: Parekh (1988) apud Mierzwa e Hespanhol (2005) 
Atualmente, há diversas tecnologias aplicáveis ao tratamento de efluentes, capazes de remover os contaminantes listados na tabela 7. Ainda conforme o mesmo autor as mais utilizadas são:

$\checkmark$ Neutralização;

$\checkmark$ Filtração e Centrifugação;

$\checkmark$ Precipitação química;

$\checkmark$ Oxidação ou redução química;

$\checkmark$ Coagulação/ floculação/ sedimentação;

$\checkmark$ Tratamento biológico;

$\checkmark$ Adsorção em carvão ativado;

$\checkmark$ Processo de separação por membranas;

$\checkmark$ Troca iônica;

$\checkmark$ Processo de separação térmica;

$\checkmark$ Stripping ou extração.

Em países do Golfo do Oriente Médio várias técnicas, convencionais e avançadas, são utilizadas para tratar esgoto. No Kuait, utilizam-se membranas de osmose reversa para remoção de sólidos dissolvidos e de ultrafiltação para remoção de microrganismos patogênicos para suprir, de forma irrestrita, a demanda dos usos não potáveis (SANTOS e MANCUSO, 2003).

Frente à grande quantidade de técnicas disponíveis para tratar efluentes e tendo em vista o foco da pesquisa em questão, serão detalhados a seguir apenas os processos biológicos com crescimento em suspensão e os de separação por membranas.

\subsection{Tratamento biológico por processo de Lodos ativados}

O tratamento biológico baseia-se na biodegradação da matéria orgânica por meio da oxidação dos compostos complexos, transformando-os em moléculas mais simples e mais estáveis. 
Há diversas variantes do tratamento biológico, dentre as quais se destaca o processo de lodos ativados que se baseia na formação de flocos compostos por bactérias e outros organismos, na presença de oxigênio, e que se acumulam em concentrações adequadas devido ao retorno de outros flocos formados previamente (METCALFF \& EDDY 1991). Esses flocos permanecem em suspensão em um reator, em contato com a matéria orgânica presente no afluente, formando um licor misto, o qual após um determinado período de tempo é conduzido a um decantador onde é feita a separação de fases. O lodo formado deposita-se no fundo do decantador e parte dele retorna ao reator biológico.

O sistema de Lodos Ativados possui duas variantes principais:

$\checkmark$ Lodos ativados convencional: esse sistema é composto por decantador primário, reator biológico e decantador secundário. Nele o tempo de detenção hidráulico de 6 a 8 horas e a idade do lodo (parâmetro que define o tempo de permanência do floco no sistema) é de 4 a 10 dias.

$\checkmark$ Lodos ativados com aeração prolongada: esse processo diferencia-se do anterior, pois não é composto por decantador primário e o tempo de permanência dos microorganismos no sistema aumenta para a faixa de $18 \mathrm{~A} 30$ dias.

Os sistemas de lodos ativados proporcionam remoção entre 95 e $98 \%$ das cargas poluidoras fato que justifica a grande aplicação dessa tecnologia no tratamento de esgoto sanitário, podendo ser aplicada também como pré-tratamento de sistemas avançados (WPCF, 1989 apud. COSTANZI, 2007)

\subsection{Tecnologia de Separação por Membranas}

Com a escassez iminente de recursos hídricos, novas tecnologias destinadas ao tratamento de água, vêm sendo alvo de pesquisas, principalmente, àquelas que favorecem a implantação da prática do reúso de água. 
Neste cenário destacam-se os processos de separação por membranas que podem ser empregados tanto no tratamento de água para abastecimento público, como no tratamento de efluentes industriais e esgotos sanitários.

Segundo (CHERYAN, 1998) a membrana atua como uma barreira seletiva sintética capaz de permitir a passagem de determinados componentes, enquanto impede a passagem de outros. De acordo com Mierzwa e Hespanhol (2005), essa barreira é capaz de separar partículas sólidas de pequeno diâmetro, bactérias, vírus, moléculas orgânicas, compostos iônicos e mesmo gases da fração líquida de um fluido.

Grande parte das membranas existentes no mercado voltado ao setor de saneamento, é fabricada a partir de compostos orgânicos. Compostos inorgânicos como cerâmicas, alumínio e aço inoxidável, também podem ser utilizados na sua fabricação, porém o alto custo de produção, na grande maioria dos casos, inviabiliza a utilização desses materiais (SCHINEIDER, 2001).

A capacidade de separação de substâncias por membranas foi observada por Abbe Nollet em 1748, quando percebeu a difusão da água de uma solução diluída para uma mais concentrada, quando separadas por uma membrana semipermeável ( BODDEKER,1995; Lonsdale 1982 apud CHERYAN, 1998). Porém, foi em 1960, com o desenvolvimento das membranas assimétricas que $\mathrm{O}$ interesse por essa tecnologia cresceu de maneira expressiva, intensificando-se, principalmente nas duas ultimas décadas, tal como indica a figura 3. Essa expressão se deve a fatores como: degradação dos mananciais; legislações mais restritivas, relacionadas à presença de contaminantes, tanto no que diz respeito à água destinada ao abastecimento público como aos efluentes lançados nos corpos receptores (MALLEVIALLE; ODENDAAL; WIESNER, 1996). 


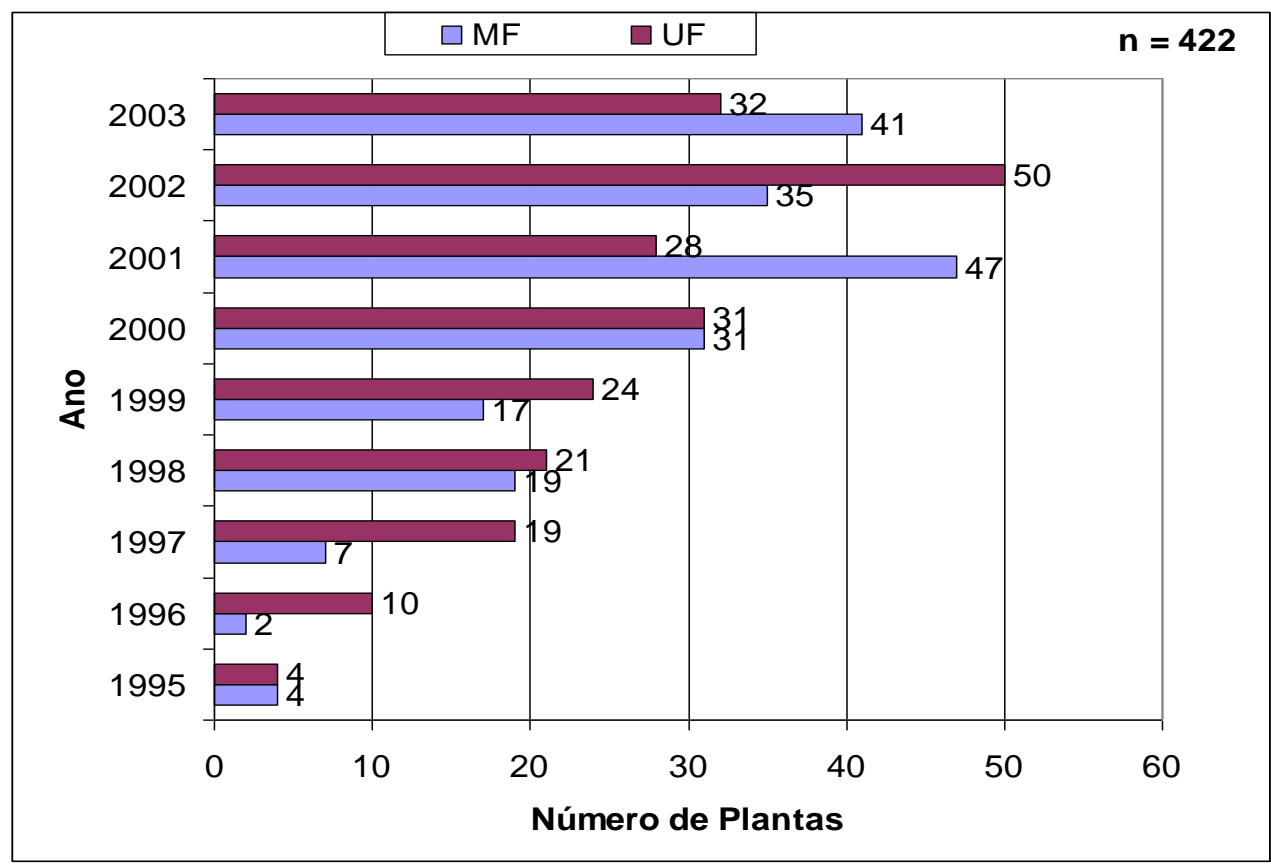

Figura 3 - Unidades de tratamento utilizando a tecnologia de separação por membranas de Microfiltração (MF) e Ultrafiltração (UF) de 1995 a 2003 (ADHAM et al., 2005 apud SILVA, 2008)

O crescimento da demanda por sistemas baseados na tecnologia de separação por membranas proporcionou a ampliação da escala de produção e, por consequência, tornou competitivo o custo das membranas em relação ao dos sistemas convencionais (MIERZWA, 2009).

Ainda conforme o mesmo autor, a tecnologia de separação por membranas apresenta algumas vantagens em relação aos sistemas convencionais utilizados para tratamento de água e esgoto. São elas:

$\checkmark$ Facilidade operacional;

$\checkmark$ A variação na qualidade do efluente pouco influencia na qualidade da água produzida;

$\checkmark$ Durante o processo de remoção de contaminantes não há consumo de produto químico;

$\checkmark$ São sistemas compactos, que conseqüentemente, necessitam de áreas reduzidas para implantação; 
A tecnologia de separação por membranas pode ser uma alternativa à substituição dos processos convencionais, os quais atendem cada vez menos às necessidades da sociedade moderna. Porém, é importante ressaltar a necessidade de se conhecer as limitações inerentes a essa tecnologia para que se atinja a máxima eficiência, técnica e economicamente.

\subsubsection{Princípios Básicos da Tecnologia de Separação por Membranas}

Os sistemas de separação por membranas, que utilizam pressão hidráulica como força motriz, se assemelham à filtração convencional, uma vez que as duas tecnologias promovem a separação física dos contaminantes presentes em uma corrente fluida. Porém, algumas diferenças básicas entre elas podem ser destacadas. Estas se encontram descritas na tabela 8.

Tabela 10- Diferença entre os processos de separação por membranas e o de filtração convencional

\begin{tabular}{lcc}
\hline Membranas & $\begin{array}{c}\text { Filtros } \\
\text { Convencionais }\end{array}$ \\
\hline $\begin{array}{l}\text { Fluxo } \\
\text { Paralelo ou perpendicular à } \\
\text { membrana } \\
\text { (nem todo fluido a ser } \\
\text { tratado atravessa a } \\
\text { membrana) }\end{array}$ & $\begin{array}{c}\text { Perpendicular ao meio } \\
\text { filtrante (todo fluido a } \\
\text { ser tratado atravessa o } \\
\text { meio) }\end{array}$ \\
\hline $\begin{array}{l}\text { Separação } \\
\text { Opessão de }\end{array}$ & $\begin{array}{c}\text { Partículas em suspensão de } \\
\text { pequeno diâmetro até } \\
\text { substâncias dissolvidas }\end{array}$ & $\begin{array}{c}\text { Partículas em } \\
\text { suspensão }\end{array}$ \\
\hline
\end{tabular}

Além do exposto na tabela 8, durante a operação de um sistema composto por membranas, a partir da corrente de alimentação, são originados dois outros fluxos denominados permeado e concentrado, conforme ilustra a figura 4. 


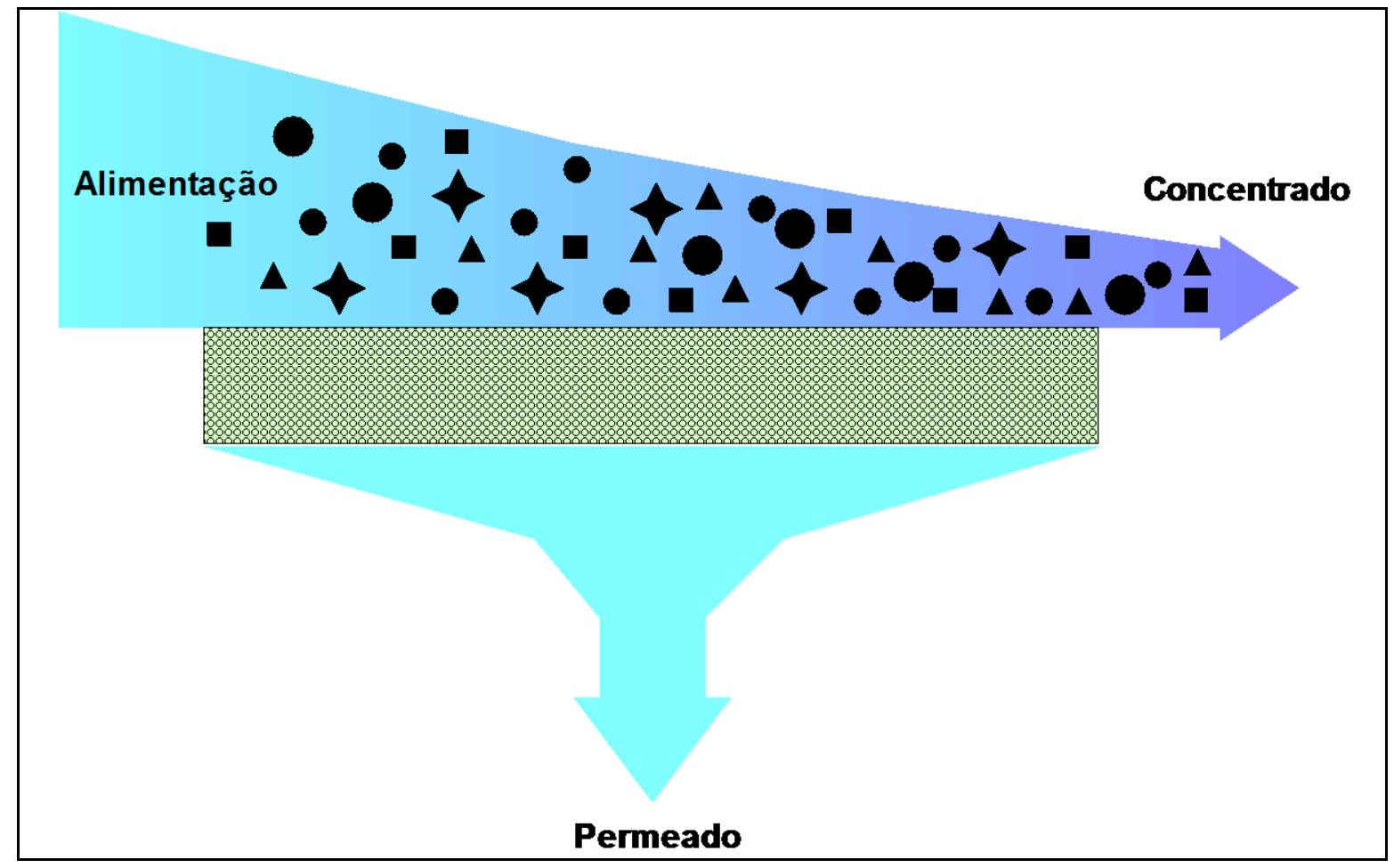

Figura 4 - Representação dos três fluxos relativos ao processo de separação por membranas

No permeado encontram-se os materiais que atravessaram a membrana e no concentrado aqueles que foram retidos.

Já, na filtração convencional, a partir de uma corrente de alimentação, dá-se origem a uma corrente de água tratada (MALLEVIALLE e WIESNER 1996).

Para que a membrana possa desempenhar sua função é necessário acondicioná-la em unidades denominada módulo. De acordo com Judd (2006), a geometria do módulo e a forma como a membrana é montada e orientada em relação ao fluxo são fatores de grande influência na determinação do desempenho do sistema.

Além da membrana, o módulo é composto por dispositivos de entrada e saída, que devem ser estruturados para suportar a pressão de operação do sistema e projetado visando os seguintes objetivos:

$\checkmark$ Favorecer condições hidráulicas que minimizem os efeitos ocasionados pela elevação da concentração de contaminantes próximos à superfície da membrana. Segundo Zeman e Zydney (1996), isso é mais facilmente obtido em 
configurações de módulos que permitam operar com fluxo de alimentação tangencial à membrana;

$\checkmark$ Disponibilizar máxima densidade de empacotamento, ou seja, maior quantidade possível de área de membrana por unidade de volume do módulo;

$\checkmark$ Minimizar os riscos de vazamento;

$\checkmark$ Manter o menor volume de fluido no seu interior;

$\checkmark$ Facilitar as operações de limpeza, montagem e desmontagem do sistema;

$\checkmark$ Permitir modularização do sistema;

$\checkmark$ Permitir menor custo por unidade de área de membrana.

Apesar da possibilidade dos módulos de membranas poliméricas apresentarem diferentes configurações, os sistemas compostos por essa tecnologia são projetados com base em dois tipos de membranas: a plana e a tubular (MULDER, 1996). Essas membranas podem ser acondicionadas de dois modos diferentes originando quatro configurações distintas de módulos:

$\checkmark$ Placa plana: módulo constituído por diversas placas (figura 5), dispostas paralelamente entre si, nas quais, além das membranas são acondicionados espaçadores e coletores de permeado.

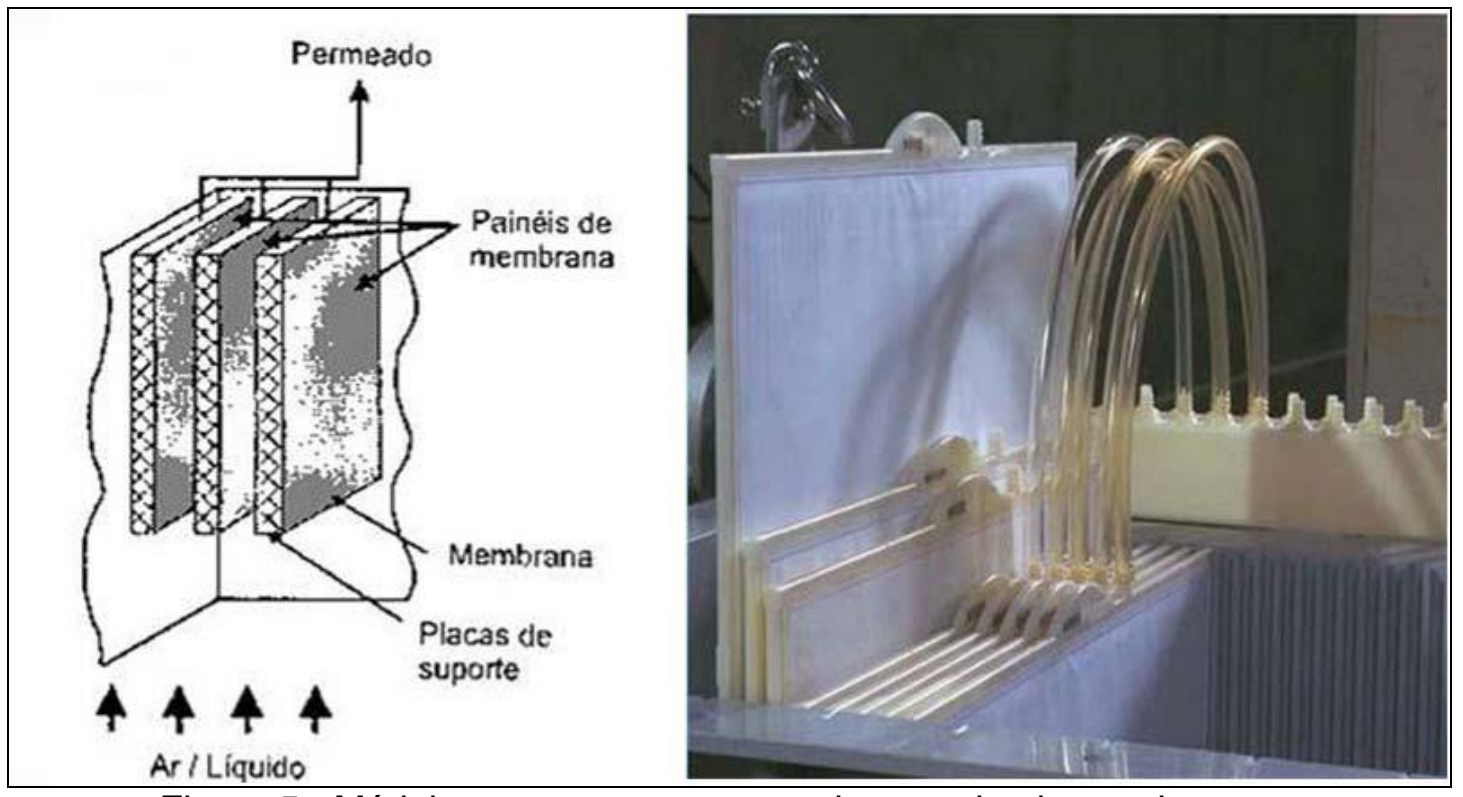

Figura 5 - Módulos compostos por membranas de placas planas

Fonte: (DECOL, 2003; CENTROPROJEKT DO BRASIL, 2004, apud VIANA, 2004) 
Além do tratamento de água, esse tipo de módulo pode ser empregado nos biorreatores de membranas destinados ao tratamento de esgoto.

$\checkmark$ Enrolado em espiral: esse tipo de módulo é composto por um vaso de pressão, dispositivos de entrada e saída de água, e cartuchos de membrana, os quais, por sua vez são constituídos de membranas planas, tubo coletor de permeado e por espaçadores que permitem a passagem do fluido.

Duas folhas de membranas planas são coladas em três lados, tendo no seu interior um espaçador, utilizado para formar o canal de permeado. Esse envelope é envolvido por um segundo espaçador, o qual possibilita a passagem do fluxo de concentrado. O conjunto é unido a um tubo central, conforme ilustra a figura 6 .

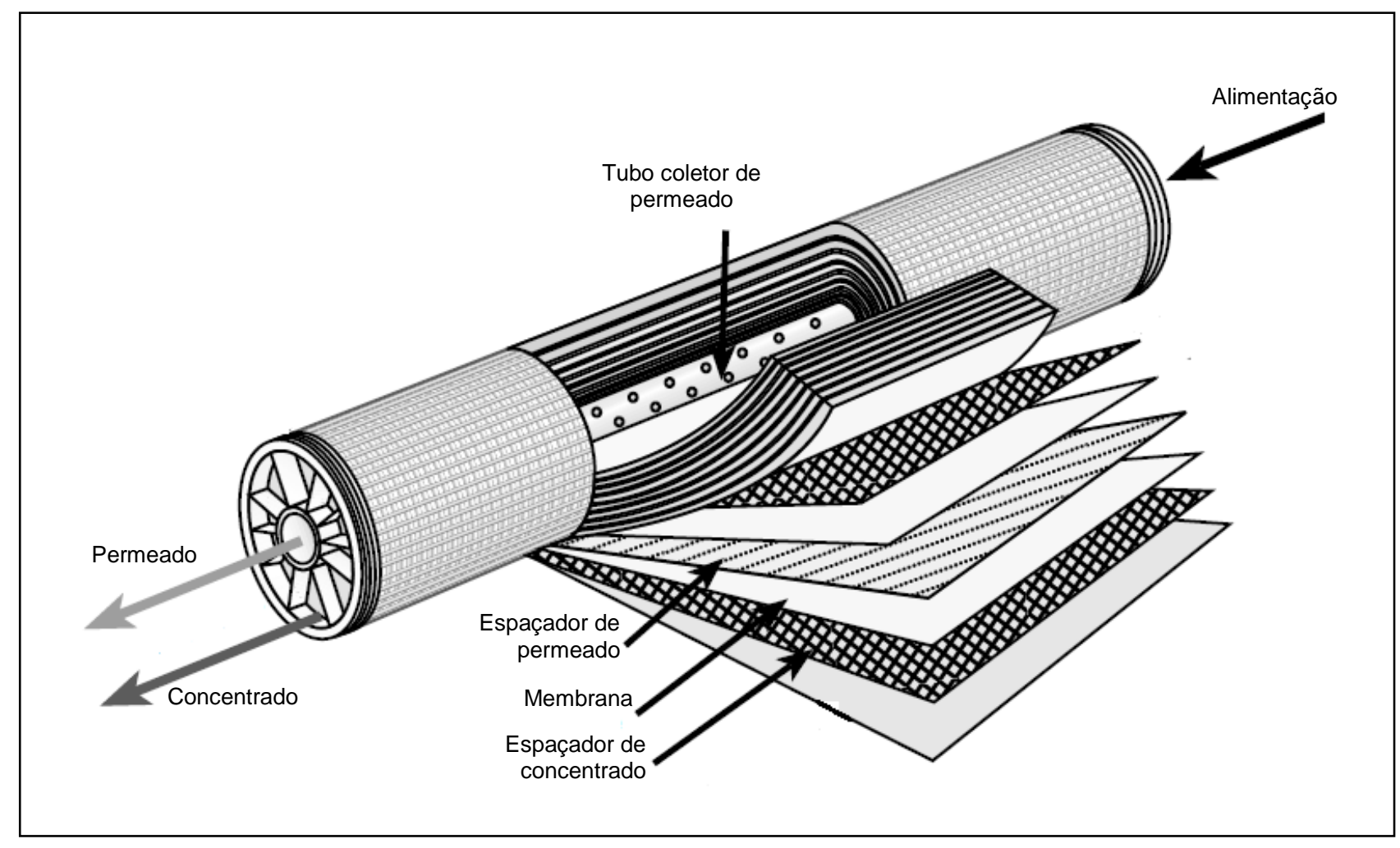

Figura 6 - Cartucho de membrana enrolada em espiral, adaptado de Wagner(2010). 
O fluxo de alimentação é bombeado ao longo do módulo e, devido à pressão de operação, parte desse fluxo transpõe a membrana dando origem ao permeado (CHERYAN, 1998).

$\checkmark$ Fibra Oca: nesse caso, um feixe de fibras é fixado nas duas extremidades do módulo por meio de resina, a qual também é utilizada para separar os compartimentos de permeado e de água bruta.

De acordo com Schneider e Tsutia (2001), a água bruta pode alimentar o sistema pelo interior da fibra, sendo o permeado recolhido no interior do vaso de pressão; ou ainda, a água bruta pode ser bombeada para dentro do vaso de pressão e o permeado é coletado na extremidade desse vaso após transpor a membrana, conforme ilustra a figura 7

Devido ao fato dos canais das membranas serem muito estreitos faz-se necessário um pré-tratamento do efluente a ser alimentado ao sistema para que a integridade física da membrana seja preservada.

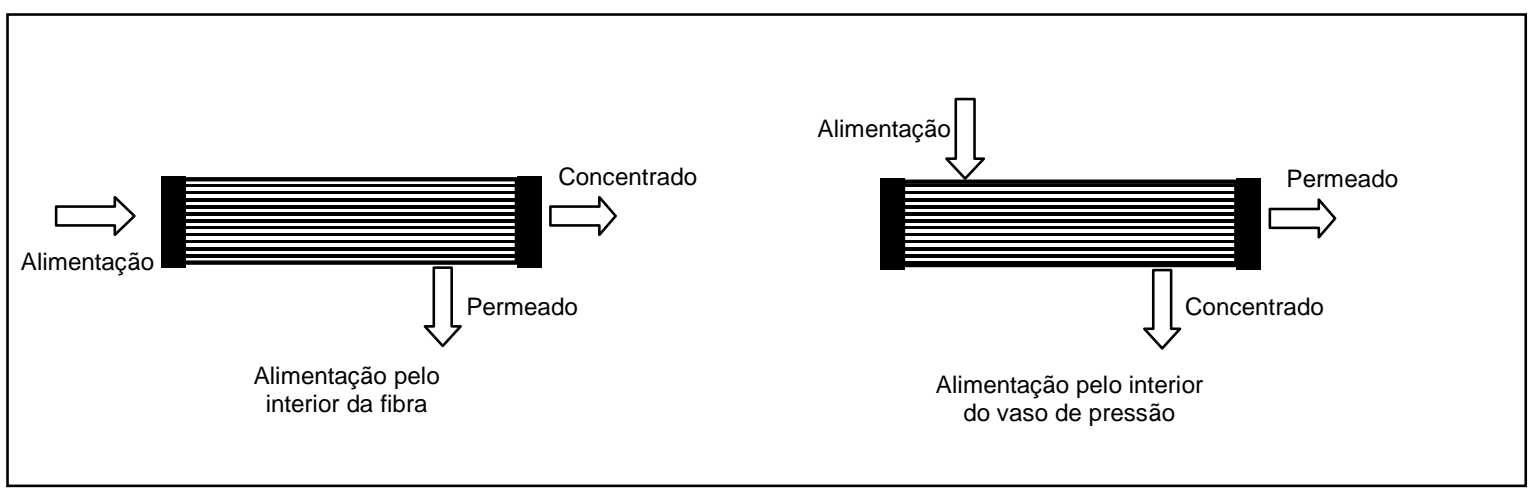

Figura 7 - Esquema da operação de módulos compostos por membranas de fibra oca, Fonte: adaptado de Zeman e Zydney, 1996.

Os módulos de fibra oca apresentam elevada densidade de empacotamento, podendo chegar a $36000 \mathrm{~m}^{2} / \mathrm{m}^{3}$ (MULDER, 1996). 
Tubular: as membranas tubulares (figura 8) apresentam forma similar às de fibra oca, porém a característica que as diferencia é o diâmetro do tubo. No caso da membrana tubular esse diâmetro pode variar de 0,3 a 2,5 cm (ZEMAN e ZYDNEY, 1996). Por apresentarem diâmetro relativamente grande, esse tipo de membrana é resistente à obstrução e dispensa pré tramento muito restritivo.

Para produzir um módulo tubular, uma película de membrana é inserida de modo a recobrir o interior de um tubo composto por material poroso, utilizado para conferir resistência mecânica à membrana. Esse tubo ou feixe de tubos é introduzido em um vaso de pressão que possui dispositivos de entrada e saída de permeado e de concentrado.

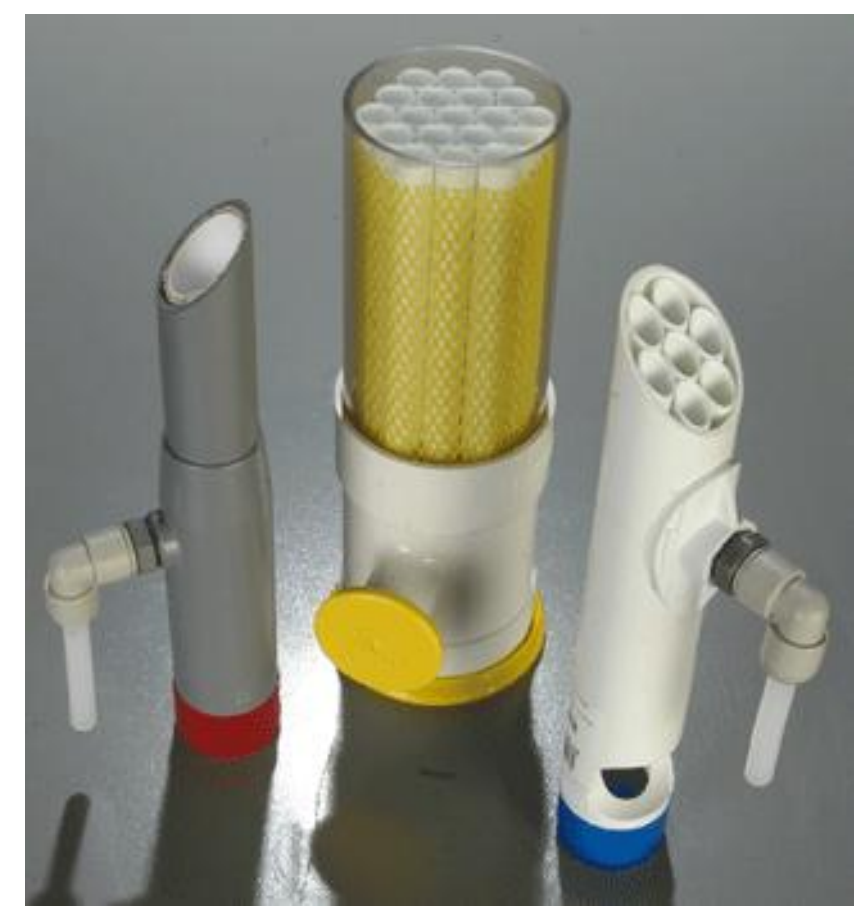

Figura 8 - Módulos de membranas tubulares

A tabela 9 apresenta, de forma sucinta, uma comparação entre os diferentes tipos de módulo compostos por membranas de material polimérico. 
Tabela 11- Comparações entre diferentes configurações de módulos

\begin{tabular}{|c|c|c|c|c|c|}
\hline $\begin{array}{l}\text { Configuraçã } \\
\text { o do módulo }\end{array}$ & $\begin{array}{l}\text { Espaçamento } \\
\text { do canal }(\mathrm{cm})\end{array}$ & $\begin{array}{c}\text { Densidade de } \\
\text { empacotamento } \\
\left(\mathrm{m}^{2} / \mathrm{m}^{3}\right)\end{array}$ & $\begin{array}{l}\text { Custo de } \\
\text { energia }\end{array}$ & $\begin{array}{c}\text { Facilidade } \\
\text { de } \\
\text { obstrução }\end{array}$ & $\begin{array}{c}\text { Facilidade } \\
\text { de } \\
\text { limpeza }\end{array}$ \\
\hline Fibra Oca & $0,02-0,25$ & 1200 & Baixo & Alta & Moderada \\
\hline Tubular & $1,0-2.5$ & 60 & Alto & Baixa & Excelente \\
\hline Placa Plana & $0,03-0,25$ & 300 & Moderado & Moderada & Bom \\
\hline $\begin{array}{l}\text { Enrolada er } \\
\text { Espiral }\end{array}$ & , & 600 & Muit & Muito alta & Ruim \\
\hline
\end{tabular}

Fonte: adaptado de Zeman e Zydney (1996).

Dentre outros fatores, durante a escolha do módulo, a questão econômica e a aplicação para qual se destina devem ser considerados (MULDER, 1996).

\subsubsection{Classificação dos processos de separação por membranas}

Atualmente, quatro diferentes tipos de membranas que utilizam a pressão hidráulica como força motriz, podem ser empregados com sucesso na área de saneamento: Microfiltração (MF), Ultrafiltração (UF), Nanofiltração (NF) e Osmose Reversa (OR).

O que diferencia cada um dos tipos citados é, basicamente, a seletividade da membrana, ou seja, sua capacidade de separar certos contaminantes, e a intensidade da pressão de operação utilizada nos sistemas. Tais características podem ser observadas na figura 9 . 


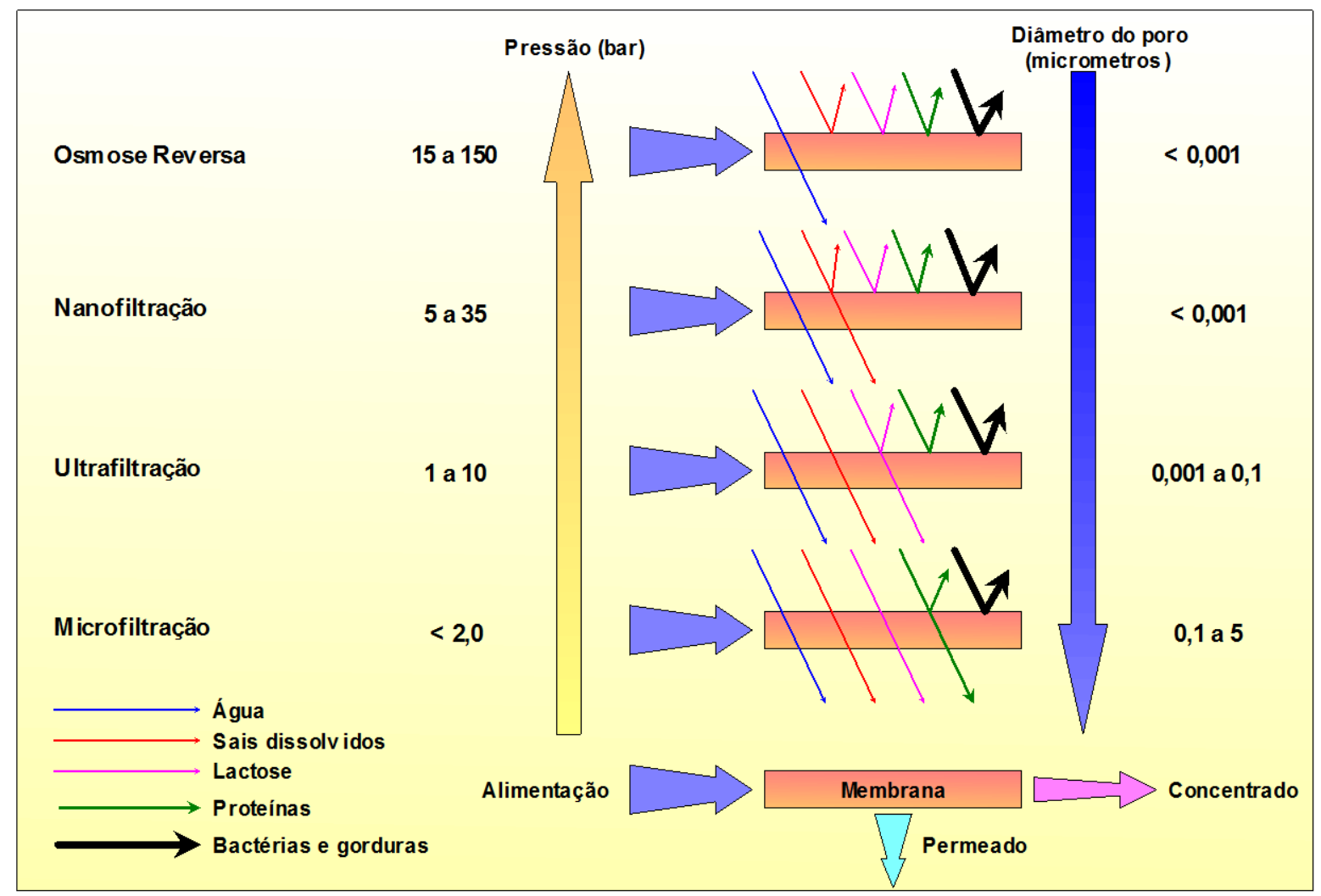

Figura 9 - Capacidade de retenção de contaminantes apresentada pelas membranas (Mierzwa, 2008)

Tendo em vista o conteúdo constante da figura 9 é possível observar um aumento de seletividade no sentido da membrana de osmose reversa para a microfiltração. Já a pressão de operação também aumenta significativamente, porém no sentido oposto.

Apesar de a figura 9 citar diâmetro de poro, para algumas membranas de ultrafiltração e, em princípio as membranas de nanofiltração e osmose reversa, denominadas membranas densas, é mais comum fazer uso da classificação em relação à massa molecular de corte, parâmetro expresso em Daltons, o que define o tamanho do contaminante capaz de ser removido pela membrana. Essa medida é definida com base na massa molecular de uma substância, a que tenha $90 \%$ de rejeição pela membrana. Porém, é necessário ressaltar que o peso molecular de corte de qualquer membrana pode variar em função das características químicas da alimentação, da interação do soluto/membrana, da configuração molecular e das condições de operação (ZEMAN e ZYDNEY, 1996). 
O processo de produção das membranas denominadas densas, não favorece a formação de poro, o que viabiliza a passagem do solvente apenas pelos interstícios formados pelo material polimérico que a compõe.

\section{$\checkmark$ Microfiltração - MF}

Dentre os processos de separação por membranas, destinados ao tratamento de água e efluentes, a Microfiltração apresenta-se como o menos restritivo em relação à separação de contaminantes, conforme ilustra a figura 9. Esse processo promove a separação de partículas em suspensão, tais como: colóides, bactérias, protozoários e grande parte dos vírus (SCHNEIDER e TSUTYA, 2001). Por outro lado, macromoléculas e sólidos dissolvidos atravessam a membrana de MF, passando a compor a corrente de permeado.

$\mathrm{Na}$ literatura é possível observar que a membrana de microfiltração pode apresentar uma variação significativa no diâmetro dos poros. A tabela 10 contém as informações relativas a essa variação apresentada por diferentes autores.

Tabela 12 Variação do diâmetro do poro das membranas de microfiltração

\begin{tabular}{lc}
\multicolumn{1}{c}{ Referências } & Diâmetro de poro $(\boldsymbol{\mu m})$ \\
\hline DAVIS (1992) & 0,02 a 10 \\
EPA (2003) & 0,1 a 0,2 \\
Schneider e Tsutya (2001) & 0,1 a 0,2 \\
Mierzwa (2005) & 0,02 a 0,4 \\
Mulder (1996) & 0,1 a 10 \\
Zeman (1996) & 0,04 a 10 \\
\hline
\end{tabular}

A MF gera um concentrado que pode representar $5 \%$ ou mais do volume alimentado e uma concentração de sólidos que capaz de atingir 70\%( Idaho, 1992 apud Mierzwa, 2005).

A pressão de operação da MF varia em geral de 0,7 a 3,5 bar e a separação das partículas em suspensão pode ser feita por peneiramento, quando a membrana apresenta diâmetro de poro menor que o diâmetro das partículas (filtração superficial), 
ou filtração em profundidade, no caso de a membrana apresenta interstícios que podem abrigar as partícula sólidas (figura10) (DAVIS, 1992).

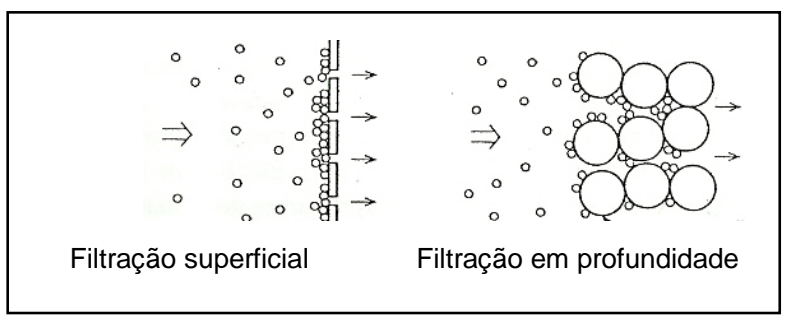

Figura 10 - Representação esquemática do tipo de separação de sólidos (Kulkarni, 1992)

Segundo Mierzwa (2005), as vantagens apresentadas pelo sistema de microfiltração são: remoção seletiva de metais, facilidade de integração a outros tratamentos, baixo consumo de energia e custo de instalação relativamente baixo.

$\checkmark$ Ultrafiltração - UF

A membrana de UF apresenta uma restrição maior à passagem de contaminantes, quando comparada à MF. Além disso, a pressão de operação pode variar entre 0,7 e 10 bar. Já a variação do diâmetro de poro pode ser observada na tabela 11.

Tabela 13 - Variação do diâmetro do poro das membranas de Ultrafiltração

\begin{tabular}{lcc}
\hline \multicolumn{1}{c}{ Referências } & Unidade & Diâmetro de poro \\
& & \\
\hline DAVIS, (1992) & $(\mu \mathrm{m})$ & $0,001 \mathrm{a} 0,1$ \\
EPA $(2003)$ & $(\mu \mathrm{m})$ & $0.01 \mathrm{a} 0.05$ \\
Schneider, $(2001)$ & $\mathrm{D}$ & $1000 \mathrm{a} 10000$ \\
Mierzwa, $(2005)$ & $(\mu \mathrm{m})$ & $0,002 \mathrm{a} 0,2$ \\
Zeman, $(1996)$ & $(\mu \mathrm{m})$ & $0,001 \mathrm{a} 0,1$ \\
\hline
\end{tabular}

Como algumas membranas de UF têm capacidade de reter macromoléculas, como açucares, polímeros e partículas coloidais, ao invés do diâmetro de poro, elas também podem ser caracterizadas pelo peso molecular de corte. 


\section{$\checkmark$ Nanofiltração - NF}

A membrana de NF é considerada densa ou não porosa (MULDER, 1996), pois o solvente flui através dos interstícios formados entre as cadeias poliméricas. Devido a essa característica tal membrana deve apresentar alta resistência mecânica, pois para que o solvente a transponha, é necessário que se aplique pressões variando entre 5 a 35 bar (MIERZWA, 2005).

Essas membranas podem ser utilizadas na separação de sais bivalentes, como Cálcio e Magnésio, e de compostos com baixa massa molecular (entre 250 a $1000 \mathrm{~g} / \mathrm{Mol}$ ).

\section{$\checkmark$ Osmose Reversa -OR}

O princípio da osmose baseia-se na passagem de um solvente, através de uma membrana semipermeável, do meio menos concentrado para o mais concentrado, até que seja atingido o equilíbrio entre as concentrações de ambas as soluções (ZEMAN e ZIDNEY, 1996). Esse fato se deve a um fenômeno denominado pressão osmótica.

No processo de osmose reversa aplica-se uma pressão, na corrente de alimentação, superior à somatória entre a pressão osmótica e a pressão necessária para vencer a perda de carga imposta pela membrana. Isso permite a passagem do solvente do meio mais concentrado para o menos concentrado.

A pressão de operação requerida por um processo de osmose depende da concentração de sólidos dissolvidos na corrente de alimentação, das propriedades da membrana e da temperatura (ZEMAN e ZIDNEY, 1996).

Tanto o processo de NF como o de OR se constituem em membrana semipermeável, como barreira para separação de contaminantes presentes em uma corrente líquida, e podem ser descritos como difusão controlada.

A OR difere da NF apenas no que se refere à eficiência na remoção de substâncias dissolvidas, principalmente íons monovalentes. 


\subsubsection{Características das Membranas}

Informações precisas sobre o uso da água que se pretende obter, e uma análise minuciosa das características quantitativas e qualitativas dos contaminantes presentes no efluente são elementos indispensáveis ao início de projetos de sistemas de membranas. Com base nesses dados elege-se a membrana mais adequada em função de características como resistência química e mecânica, propriedades superficiais e morfológicas - todas conferidas pela técnica e materiais usados em sua fabricação. As informações relativas à corrente a ser tratada são necessárias, entre outras coisas, porque os contaminantes nela presentes terão forte influência na redução da taxa de produção da membrana (relação entre fluxo do permeado e o da alimentação). Devese considerar que a área de membrana necessária - e, portanto o custo de implantação do sistema - é inversamente proporcional à taxa de produção acima referida.

A produtividade de uma membrana limpa pode ser representada pelo fluxo que a transpõe, calculado pela equação da lei de Darcy (Wiesner, 1996):

$$
I=\frac{\Delta \mathrm{P}}{\mu R m}
$$

Onde:

$\mathrm{J}=$ Produtividade da Membrana

$\Delta \mathrm{P}=$ diferença de pressão transmembrana

$\mu=$ viscosidade

$R_{m}=$ resistência hidráulica da membrana limpa 
No que se refere à capacidade de produção das membranas, há variação na taxa de produção em função do tipo de membrana. A tabela 12 apresenta a faixa de variação de fluxo para cada uma das membranas que utilizam pressão como força motriz.

Tabela 14 - Variação da taxa de fluxo em função do tipo de membrana

\begin{tabular}{lc}
\multicolumn{1}{c}{ Referências } & Taxa Fluxo $\left(\mathrm{L} \cdot \mathrm{h}^{-1} \cdot \mathrm{m}^{-2}\right)$ \\
\hline Osmose Reversa & 15 a 25 \\
Nanofiltração & 20 a 30 \\
Ultrafiltração & 25 a 50 \\
Microfiltração & Não há uma regra geral \\
\hline Fonte: PROSAB 4 (2006) &
\end{tabular}

Porém, durante a operação do sistema ocorre o aporte de contaminantes à superfície da membrana, originando outra resistência ao fluxo que se somará à resistência hidráulica, determinando a redução deste (MULDER, 1997).

Dentre as características morfológicas da membrana, parcialmente responsáveis pelo fluxo transmembrana, destacam-se:

\section{$\checkmark$ Presença ou ausência de poros}

Uma membrana pode ser considerada porosa quando, em sua estrutura, há presença de poros que possibilitam a passagem do solvente e impedem que certos contaminantes componham a corrente de permeado. Quanto maior a porosidade, ou seja, a quantidade de poros por unidade de área, maior será o fluxo através da membrana.

Já nas membranas densas ou não porosas, devido à ausência de poros a passagem do fluxo é feita através dos interstícios existentes entre as cadeias poliméricas que formam sua estrutura. Nesse tipo de membrana a passagem do solvente ocorre pelo mecanismo de difusão e a separação dos contaminantes é promovida pela diferença na solubilidade e/ou difusividade (MULDER, 1997). 
Ainda de acordo com o mesmo autor, uma membrana é considerada densa quando a solução polímero/solvente apresenta uma concentração de polímero superior a $15 \%$.

\section{$\checkmark$ Diâmetro dos poros}

Essa característica conferirá o grau de seletividade à membrana, ou seja, quanto maior o diâmetro do poro, menos restritiva será a membrana e, conseqüentemente, maior será o fluxo de permeado. De acordo com critérios da Internatinal Union of Pure and Applied Chemistry - IUPAC, os poros são classificados em função do diâmetro, da seguinte maneira:

- Macroporo - Diâmetro dos poros > $50 \mathrm{~nm}$

- Mesoporo - Diâmetro dos poros entre 2 e $50 \mathrm{~nm}$

- Microporo - Diâmetro dos poros $<2 \mathrm{~nm}$

\section{$\checkmark$ Simetria ou Assimetria}

As membranas são denominadas simétricas ou isotrópicas quando apresentam poros com as mesmas características ao longo da seção transversal. Já as membranas que apresentam ao longo da mesma seção características distintas são denominadas assimétricas ou anisotrópicas, conforme pode ser observado a na figura 11.

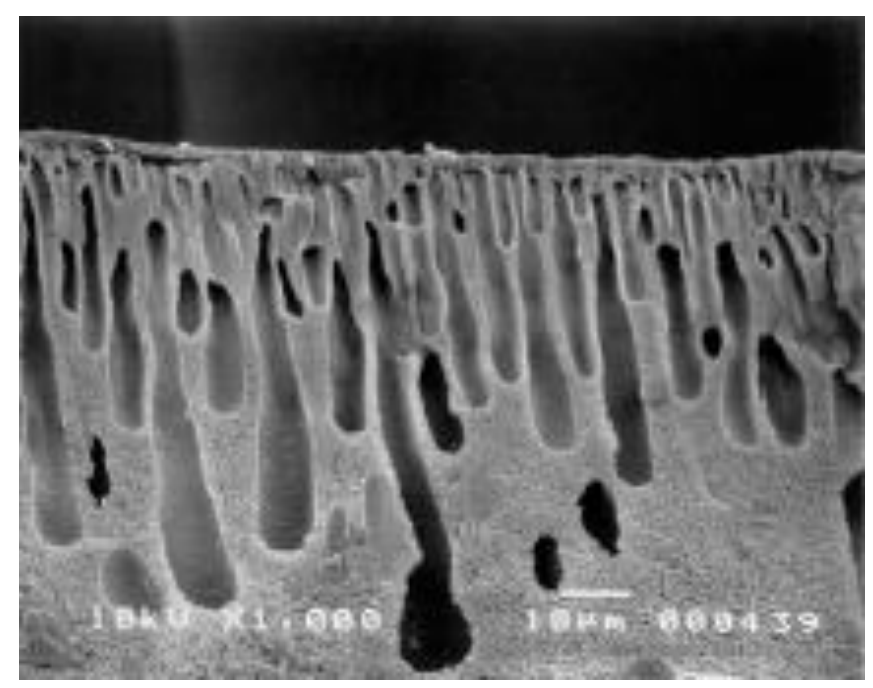

Figura 11 - Seção transversal de uma membrana assimétrica (Choi, 2002) 
Observando a figura 11 percebe-se que na superfície o diâmetro dos poros é menor que ao longo da seção transversal. Esse fato confere a seletividade à membrana e, em relação à membrana simétrica, promove a redução da resistência à passagem do fluido, uma vez que o diâmetro dos poros aumenta ao longo da espessura e, com isso reduz a perda de carga durante a passagem do solvente pela membrana.

\section{$\checkmark$ Hidrofilicidade ou Hidrofobicidade}

Hidrofilicidade ou hidrofobicidade são características que definem o grau de afinidade da membrana pela água. Esse grau é medido a partir do ângulo de contato formado entre uma gota de água e a superfície da membrana.

A figura 12 ilustra a formação do ângulo de contato entre a gota e a superfície das membranas hidrofílica e hidrofóbica.

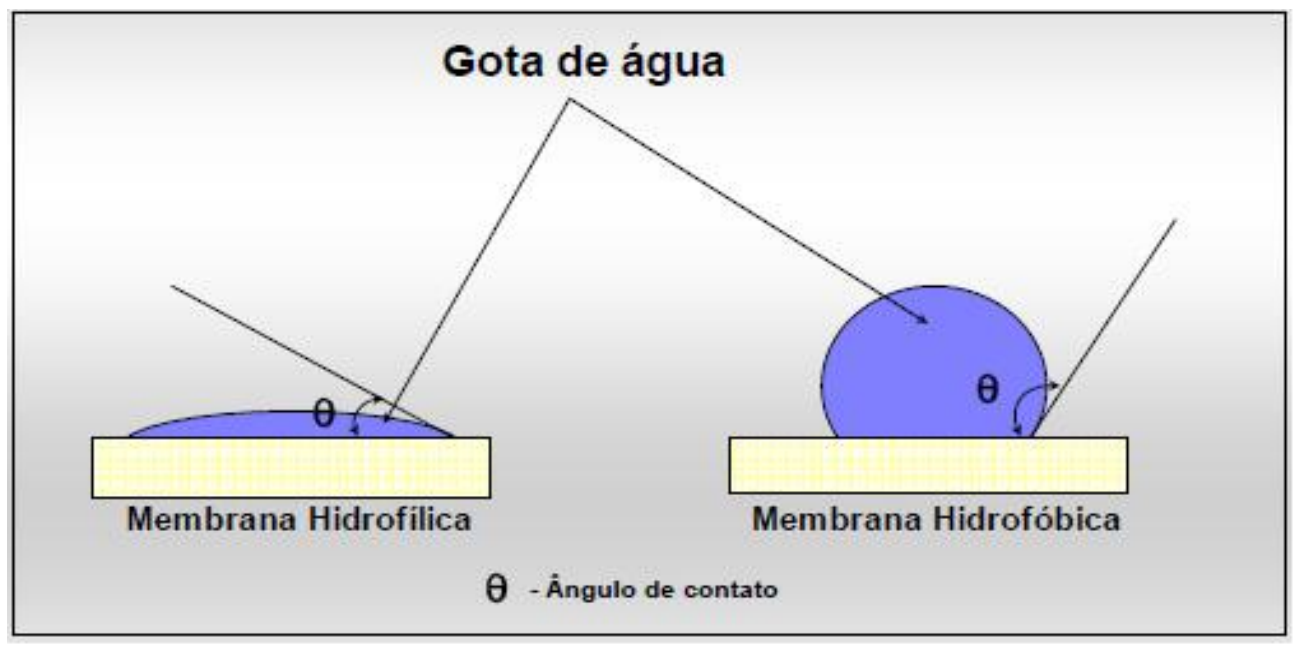

Figura 12 - Representação do ângulo de contato entre a gota de água e a superfície da membrana

Para o tratamento de água o ideal é que a membrana seja hidrofílica (Cheryan, 1998), pois essa característica reduz o potencial de depósito na sua superfície, já que devido 
às propriedades do material, a água é atraída para a superfície e, conseqüentemente os contaminantes são repelidos.

De acordo com (Mulder, 1997) existem diferentes polímeros que podem conferir à membrana hidrofilicidade ou hidrofobicidade conforme apresentado na tabela 13.

Tabela 15 - Materiais que conferem hidrofilicidade ou hidrofobicidade à membrana

\begin{tabular}{ll}
\hline $\begin{array}{c}\text { Característica da } \\
\text { Membrana }\end{array}$ & \multicolumn{1}{c}{ Material } \\
\hline & - Politetrafluoretileno (PTFE) \\
Hidrofóbica & - Fluoreto de polivinilideno (PVDF) \\
& - Polipropileno (PP) \\
& - Polietileno (PE) \\
& - Ester de celulose \\
Hidrofílica & - Polisulfona (PSF) \\
& - Poliamida (PI) \\
& - Polietercetona (PEEK) \\
\hline
\end{tabular}

Outro fator de extrema importância é a afinidade química do material da membrana pelos contaminantes presentes na corrente a ser tratada, dado que uma possível interação entre eles pode causar danos irreversíveis, podendo levar à perda da membrana.

\subsubsection{Características Operacionais do Sistema e o Desempenho da Membrana}

Segundo Cheryan (1998), os fatores que podem interferir, de forma significativa, no fluxo de permeado são:.

\section{$\checkmark \quad$ Temperatura}

Esse parâmetro tem efeito direto no fluxo de permeado, uma vez que interfere na viscosidade do fluido. A cada grau de alteração de temperatura há uma variação de $3,3 \%$ no fluxo transmembrana. 
A temperatura interfere na solubilidade de alguns compostos, podendo favorecer a reprodução de microorganismos, ou ainda, a precipitação de substâncias, fato que pode favorecer a formação de uma camada aderida à superfície da membrana

\section{$\checkmark \quad$ Taxa de recuperação de água}

A taxa de recuperação de água é a relação entre as vazões de permeado e de alimentação que compõem o sistema. A princípio, pode parecer mais adequado trabalhar com altas taxas de recuperação. Porém, essa prática pode potencializar o fenômeno da polarização de concentração, favorecendo a contaminação e a redução do fluxo de permeado.

Segundo Mierzwa (2006), essa taxa de recuperação por módulo de membrana é de $10 \%$, ou seja, um décimo da vazão de alimentação é convertido em permeado. Porém, a taxa de recuperação global do sistema é função do tipo de arranjo das membranas, cujos módulos podem ser dispostos em série ou, ainda, pode-se utilizar a recirculação do concentrado. Essas duas opções devem ser avaliadas de modo a permitir a maior recuperação possível de água.

\section{$\checkmark \quad$ Pressão de operação}

A pressão afeta diretamente a taxa de recuperação da membrana. No caso da OR e da NF a relação entre o fluxo e a pressão é apresentada na figura 13.

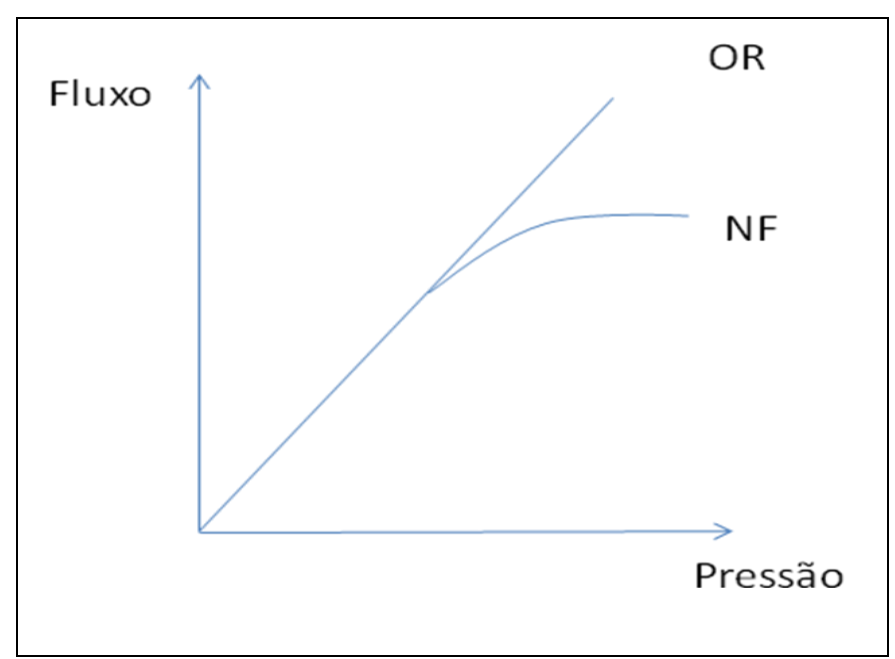

Figura 13 - Relação entre a pressão e o fluxo de permeado nas membranas de OR e NF 
A figura 13 mostra que, no caso da $\mathrm{OR}$, a pressão interfere de forma linear no fluxo de permeado. Já na membrana de NF a interferência é semelhante, porém a partir de um dado patamar percebe-se mudança de comportamento.

No caso das membranas de MF e UF, acima de um determinado valor de pressão, há uma queda no fluxo de permeado. Isso se deve ao fato desses sistemas tolerarem a presença de sólidos em suspensão no fluido a ser tratado e, com isso, uma elevação na pressão de operação promove a compactação da camada formada por esses contaminantes sobre a membrana, reduzindo, ou em alguns casos, impedindo a passagem do fluxo, conforme ilustrado na figura 14

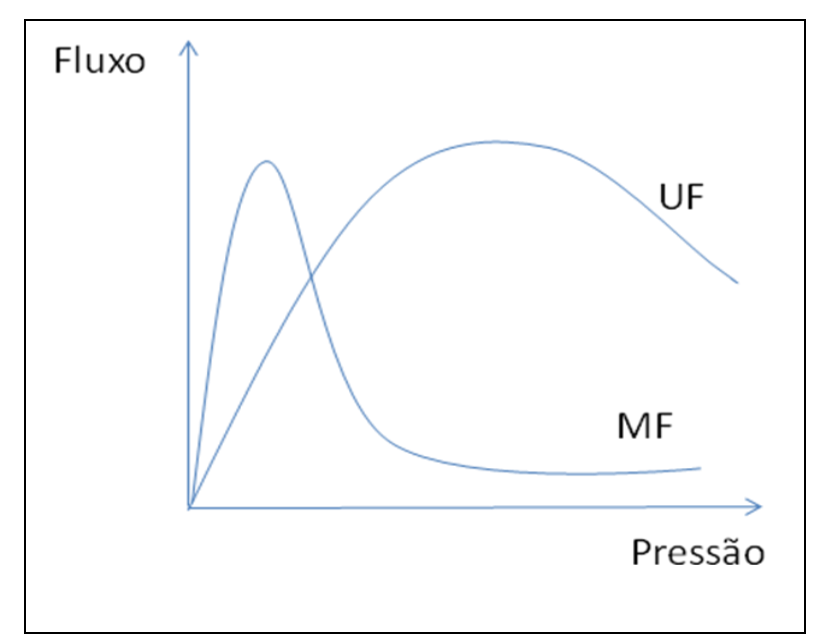

Figura 14 Relação entre a pressão e o fluxo de permeado nas membranas de MF e UF

Para que as membranas não sofram danos em sua estrutura física durante a operação do sistema, os fornecedores estabelecem limites máximos para a pressão transmembrana $\left(\mathrm{P}_{\mathrm{T}}\right)$. Esse parâmetro pode ser calculado utilizando-se a equação 02 proposta por Cheryan (1998).

$$
P_{T}=P_{F}+P_{P}
$$


Onde:

$\mathrm{P}_{\mathrm{T}}=$ Pressão Transmembrana

$\mathrm{P}_{\mathrm{F}}=$ Pressão de alimentação

$\mathrm{P}_{\mathrm{P}}=$ Pressão na saída do permeado

No mesmo contexto a pressão de alimentação será calcula por meio da expressão indicada pela equação 03 , a partir da média aritmética entre as pressões de entrada e saída da membrana:

$$
P_{F}=\frac{P_{i}+P_{0}}{2}
$$

Onde:

$\mathrm{P}_{\mathrm{i}}=$ Pressão na entrada da membrana

$\mathrm{P}_{0}=$ Pressão de saída da membrana

\subsubsection{Interferências dos contaminantes no desempenho das membranas}

Conforme já explicitado, as membranas devem ser escolhidas em função do tipo de contaminantes presentes na corrente de alimentação do sistema. Essas substâncias podem ser orgânicas ou minerais, biodegradáveis ou não, além de poderem estar presente segundo três formas distintas:

$\checkmark$ Em suspensão;

$\checkmark$ Na forma de colóide; 
$\checkmark$ Dissolvida;

A concentração de contaminantes na corrente de alimentação é outra variável que interfere, de forma significativa, no desempenho da unidade, pois durante a operação de um sistema de separação por membranas, as características hidrodinâmicas, intrínsecas ao movimento do fluido, promovem o arraste dessas substâncias em direção à interface solução/membrana, o que resulta no surgimento de uma camada limite com elevada concentração de solutos nessa região.

A espessura dessa camada é função das características operacionais do sistema em relação ao fluxo da corrente de alimentação, que pode ser perpendicular ou tangencial à superfície da membrana, processos denominados dead end e crossflow, respectivamente, como mostra a figura 15 .

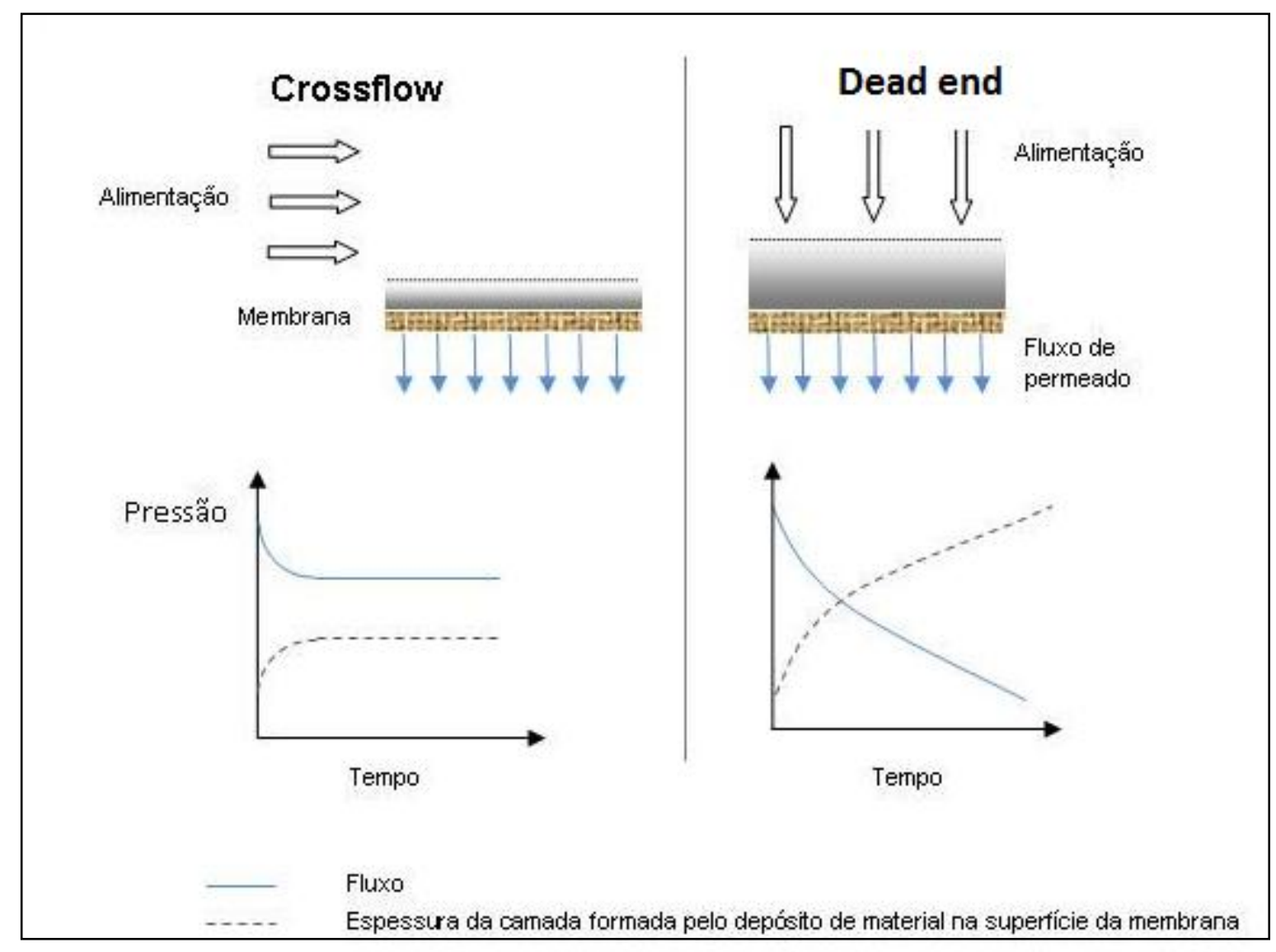

Figura 15 - Esquema simplificado de variação do fluxo em um processo de separação por membranas operando em sistema deadend e crossflow (KULKARNI, 1992) 
Em um sistema que opere com fluxo deadend a espessura da torta formada pelo depósito de materiais aumenta com o tempo de operação, o que provoca uma elevação na resistência à passagem do solvente e, conseqüentemente, uma redução no fluxo de permeado. Sendo assim, nesse sistema são necessárias paradas periódicas para que se restabeleça o fluxo.

Já no sistema crossflow, o fluxo tangencial limita a espessura da camada formada pelo depósito de solutos, estabelecendo-se um perfil de concentrações que é função do perfil de velocidade, de acordo com a figura16.

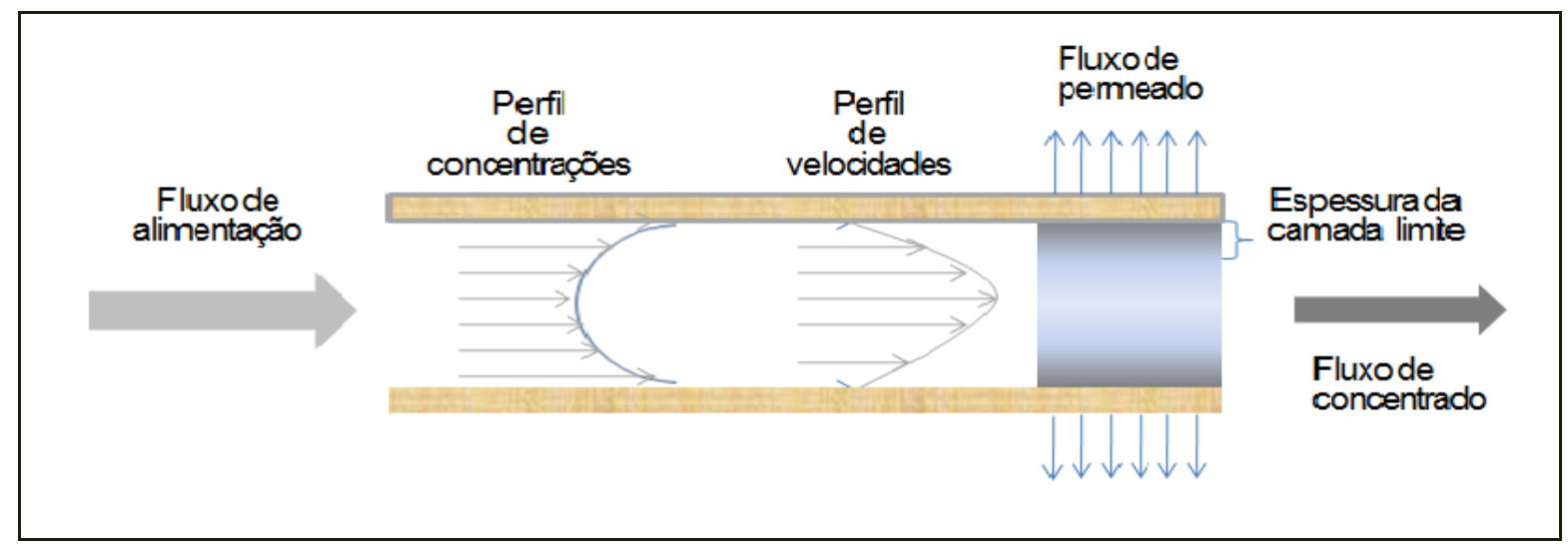

Figura 16 - Representação do perfil de concentração de soluto em função velocidade de escoamento ao longo da seção transversal de uma membrana tubular operando com sistema crossflow

$\mathrm{Na}$ figura 16 é possível observar que quanto mais próximo da membrana, onde a velocidade de escoamento tende a zero, a concentração de soluto é mais elevada. Enquanto que a certa distância da membrana, onde a velocidade de escoamento é máxima a concentração de soluto é menor.

Esse aporte de contaminantes à superfície da membrana origina, basicamente, dois fenômenos conhecidos como "polarização de concentração" e "fouling". 


\subsubsection{Polarização da Concentração}

A causa da polarização de concentração é o aumento da concentração de soluto próximo à superfície da membrana, originando um processo difusivo em direção oposta à mesma, formando um perfil de concentração decrescente dos compostos.

Tal perfil, denominado gradiente de concentração, origina a camada limite determinada pela espessura da região polarizada (Viana, 2004), a qual, conforme já explicitado, é determinada pelas características hidrodinâmicas do sistema.

$\mathrm{Na}$ figura 16 é possível observar que quanto maior a distância da superfície da membrana maior é a velocidade do fluido. Sendo assim, maior é a força disponível para promover o arraste de partículas, fato que explica a redução gradativa da concentração de contaminantes no sentido oposto ao da superfície da membrana.

Os efeitos de polarização de concentração devem ser revertidos, adotando-se algumas alterações nas características operacionais do sistema como: redução na pressão transmembrana, redução da concentração de contaminantes na corrente de alimentação e elevação na velocidade de fluxo (Cheryan, 1998). Conforme apontado por Schneider e Tsutya (2001), a presença de espaçadores de concentrado, no caso de membranas planas, e o aumento na velocidade do fluido na alimentação, no caso de sistemas crossflow, são artifícios utilizados para minimizar esse fenômeno.

Como os sistemas de separação por membranas apresentados utilizam a pressão como força motriz, ao longo da operação esses contaminantes vão sendo compactados, fazendo com que aumente concentração do soluto, próximo à membrana, dando origem à denominada camada gel. Essa camada, que pode ser vista na figura 17, aumenta a resistência à passagem do fluido, contribuindo diretamente para uma redução no desempenho do sistema. 


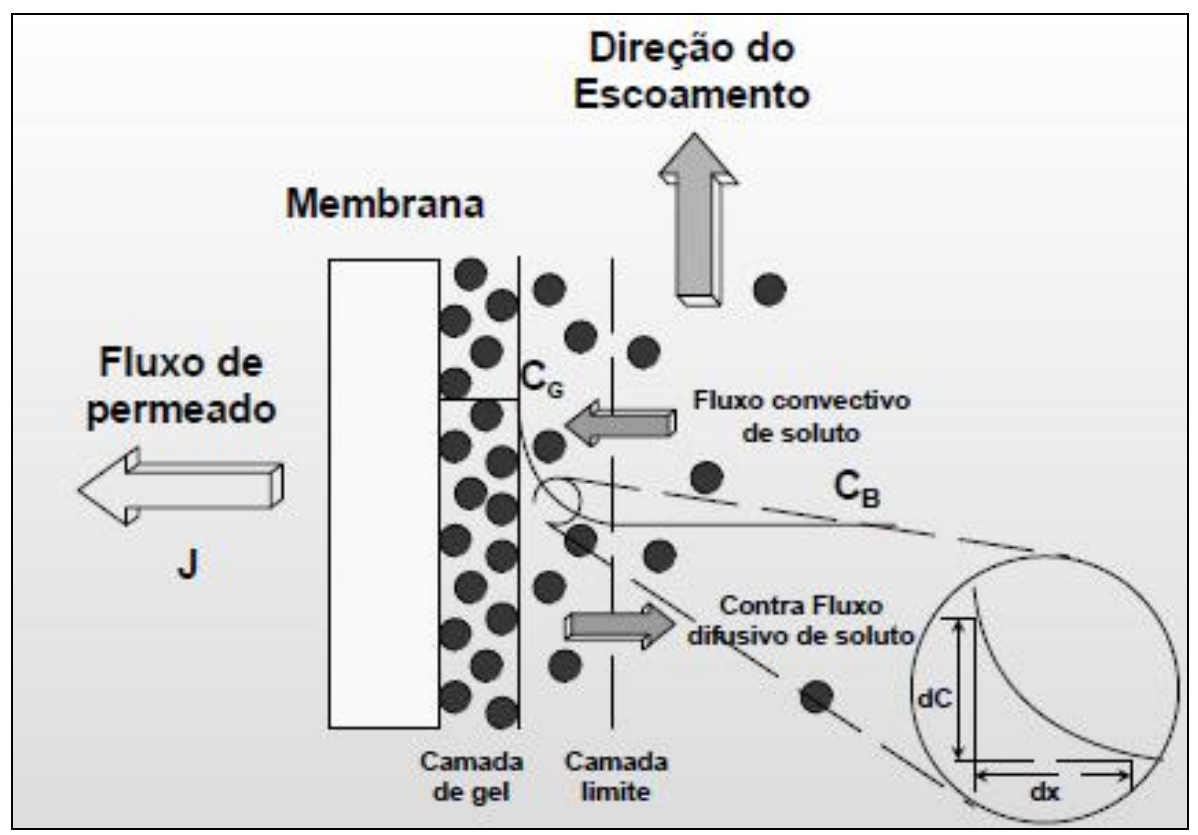

Figura 17 - Esquema simplificado da Teoria do filme - Modelo de transferência de massa

\subsubsection{Fouling ou depósito}

O fenômeno denominado fouling é o resultado da interação físicas e/ou químicas do material da membrana com os solutos presentes na corrente de alimentação. A substância que o ocasiona não, necessariamente, é aquela que apresenta as maiores concentrações na corrente de alimentação (Zeman, 1996).

No caso da ultrafiltração, a influência do fouling é particularmente importantes, uma vez que a produtividade do sistema é, de fato, limitada pela transferência de massa que ocorre na camada de polarização, próximo à superfície da membrana. Isso pode ser explicado pelo fato de que as macromoléculas retidas pela membrana apresentam baixos coeficientes de difusão. A redução do fluxo de permeado e a alteração na seletividade da membrana podem ser consideradas como indicadores da presença desse fenômeno.

Com relação à alteração da seletividade, quando o acúmulo de sólidos na superfície da membrana é significativo, este pode atuar como uma segunda barreira seletiva, aumentado a restrição à passagem de contaminantes (Cheryan, 1998). 
Diferentemente do fenômeno de polarização de concentração, em geral, o fouling não pode ser eliminado, simplesmente, elevando-se a taxa de transferência de massa do soluto.

O fouling pode provocar alterações morfológicas na membrana, principalmente aquelas relativas à degradação química, ocasionadas por fatores operacionais do sistema como $\mathrm{pH}$ e temperatura da solução a ser tratada, bem como a utilização de agentes de limpeza que apresentem incompatibilidade com material utilizado na composição da membrana. Além disso, dependendo da natureza e da extensão do fouling, restaurar o fluxo pode requerer agentes de limpeza agressivos, que reduzem de forma significativa a vida útil da membrana.

\subsubsection{Formação de biofilme}

Outro problema que compromete de forma significativa o desempenho global de um sistema de separação por membranas é a formação do denominado biofilme. Tal fenômeno resulta no crescimento de microorganismos como algas, fungos e bactérias, aderidos à superfície da membrana. A formação de biofilme se inicia com o aporte à superfície da membrana de microorganismos que excretam uma substância polimérica, das quais se servem para se fixar na membrana. Reproduzindo-se, esses microorganismos formam o biofilme e a substância utilizada em sua fixação protege-os de agentes externos, dificultando, por exemplo, a ação de desinfetantes.

Segundo Schneider, 2001 e como já explicitado, a redução inicial do fluxo que ocorre de forma rápida, é devida à concentração da polarização. Em seguida, em média nas 4 primeiras horas de operação, o fluxo passa a ter queda mais lenta, porém constante, devido à colonização da membrana por microorganismos.

O fenômeno de polarização de concentração favorece o crescimento microbiano devido à grande disponibilidade de nutrientes concentrados na região próxima à superfície da membrana

Uma vez aderidas à superfície da membrana, as bactérias pode se desenvolver formando colônias, conforme ilustra a figura 18. 


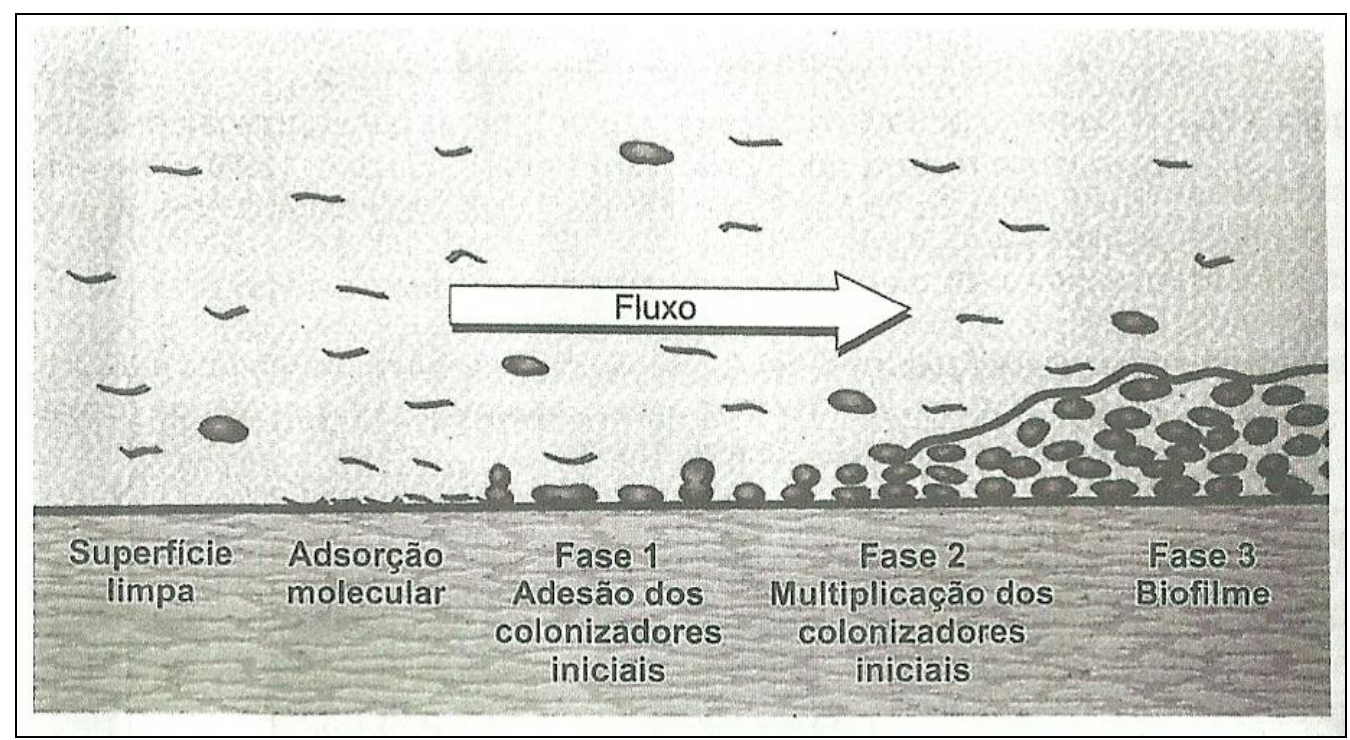

Figura 18 - Processo de formação do biofilme Fonte: SCHNEIDER, 2001

O controle do biofilme é muito complexo pois a principal fonte de contaminação é a própria água a ser tratada. Na grande maioria das vezes, esta contém uma elevada concentração de microorganismos capazes de promover a formação de colônias na superfície da membrana. Além disso, nesse próprio meio aquoso estão presentes os nutrientes, como proteínas, ácidos orgânicos, polissacarídeos e lipídeos, necessários ao crescimento desses microorganismos (Zeman,1996).

O Mecanismo de elevação da velocidade do fluxo limita a espessura do biofilme, porém não é efetivo para sua remoção. Nesse caso é necessário que a operação do sistema seja interrompida e se promova a limpeza química e sanitização dos componentes do sistema.

\subsubsection{Fluxo Crítico}

Os fenômenos relativos à formação de biofilme, polarização da concentração e depósito de contaminantes na superfície da membrana são responsáveis por uma redução gradual no fluxo de permeado. Na maioria dos casos, elevar a pressão de operação 
não melhora a produtividade da membrana. Ao contrário, pode reduzir ainda mais 0 fluxo de permeado, uma vez que promove a compactação dos contaminantes presentes na superfície da membrana, dificultando ainda mais a passagem da água.

O fluxo crítico é um dos principais parâmetros operacionais e está diretamente relacionado à eficiência da membrana com relação à produção de permeado. De acordo com Field (1995) e Howell (1995) apud Kwon et al (2000) o fluxo crítico é definido como aquele abaixo do qual não ocorre a redução na vazão de permeado com o aumento da pressão de operação, ou seja, a relação entre vazão de permeado e pressão aplicada é linear. Acima desse determinado fluxo a relação deixa de ser linear devido à formação e compactação da camada gel em razão de características hidrodinâmicas do sistema, que permitem maior aporte de partículas à superfície da membrana.

O Fluxo crítico pode ser determinado obtendo-se a variação no volume de permeado em função da pressão de alimentação.

Quando a membrana é operada com água limpa a relação entre vazão de permeado e pressão de operação é linear, porém quando a membrana é utilizada para tratar efluentes com sólidos em suspensão a relação citada, a partir de um determinado ponto, deixa de ser linear, estabelecendo-se o fluxo crítico, conforme ilustra o esquema apresentado na figura 19 


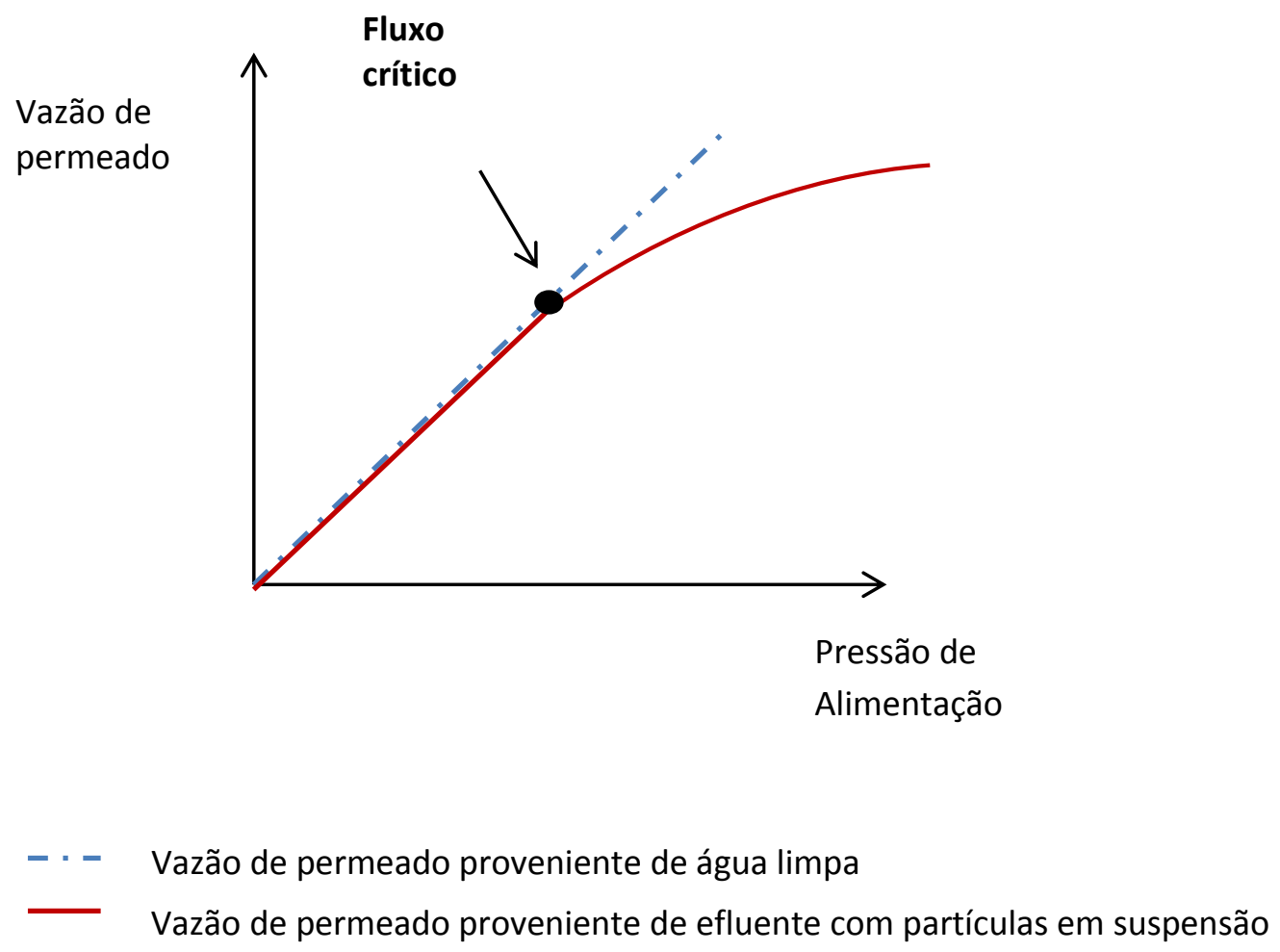

Figura 19- Representação do Fluxo Crítico (Field et al. 1995 apud de BEZERRA, 2010)

A partir da interpretação do gráfico é possível afirmar que estabelecer pressões de operação elevadas não significa aumentar a produtividade do sistema.

\subsubsection{Projetos de sistemas de separação por membranas}

Para iniciar o projeto de um sistema de separação por membranas será necessário, basicamente, conhecer as características quantitativas e qualitativas do efluente a ser tratado e a qualidade da água que se deseja obter. Em função dessas informações escolhe-se o processo de separação a ser utilizado, dentre as opções disponíveis, (MF, UF, NF ou OR). 
Além disso, a porcentagem de recuperação de água, a taxa de produção da membrana (dada pelo fornecedor) e a vazão de água a ser tratada, são informações necessárias ao desenvolvimento do projeto.

De acordo com Wagner (2001), os valores típicos da taxa de produção de água através das membranas são:

OR - 15 a $25 \mathrm{~L} / \mathrm{h} \cdot \mathrm{m}^{2}$

$\mathrm{NF}-20$ a $30 \mathrm{~L} / \mathrm{h} \cdot \mathrm{m}^{2}$

UF - 25 a $50 \mathrm{~L} / \mathrm{h} \cdot \mathrm{m}^{2}$

MF - não há regra

A variação da concentração de contaminantes no rejeito em função da operação do sistema, está relacionado não só à taxa de recuperação mas também à taxa de rejeição da membrana $(R)$. A taxa de rejeição pode ser calculada pela expressão a seguir (CHERYAN, 1998):

$$
R=1-\frac{C_{P}}{C_{R}}
$$

Onde:

$\mathrm{R}=$ Taxa de Rejeição da Membrana

$\mathrm{C}_{\mathrm{P}}=$ concentração do permeado

$\mathrm{C}_{\mathrm{R}}=$ concentração do rejeito

O fator de concentração pode ser calculado por meio da equação 05 (SILVA, 2009):

$$
F C=\frac{1-Y \cdot(1-R)}{(1-Y)}
$$


$\mathrm{Y}=$ Taxa de recuperação de água

A taxa de recuperação de água está diretamente ligada à quantidade de contaminantes presentes na corrente de alimentação. Quando se adota uma alta taxa de recuperação o volume de rejeito é menor, porém a concentração de contaminantes nessa corrente aumenta, favorecendo o fenômeno de polarização de concentração.

A figura 20 apresenta a relação entre o fator de concentração e o fator de redução do volume de concentrado (FRV).

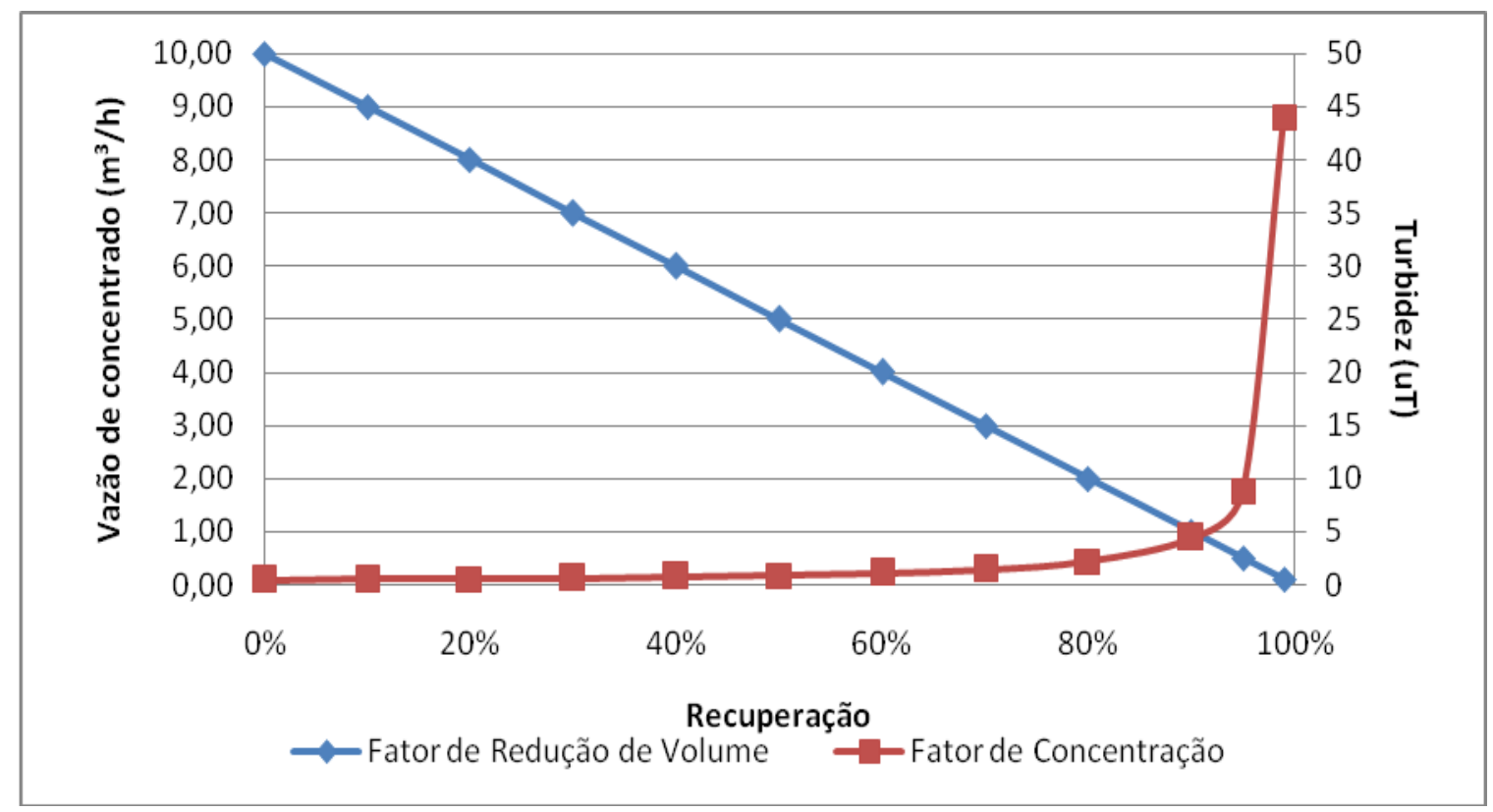

Figura 20- Fator de Concentração em função do Fator de Redução de Volume do concentrado.

Observando-se o gráfico da figura 20 percebe-se que quanto menor o volume de concentrado gerado, ou seja, quanto maior a recuperação de água, maior será o fator de concentração.

A taxa de recuperação de água pode ser calculada por membrana $\left(\mathrm{Y}_{\mathrm{M}}\right)$ ou, ainda do sistema como um todo, denominada recuperação global $\left(\mathrm{Y}_{\mathrm{G}}\right)$.

A eficiência de um sistema de membranas também está relacionada às características da operação. Existem três formas distintas de fluxo para membranas de MF e UF que operam em processo contínuo (CHERYAN, 1998). Estes são apresentados nas figuras 21,22 e 23. 


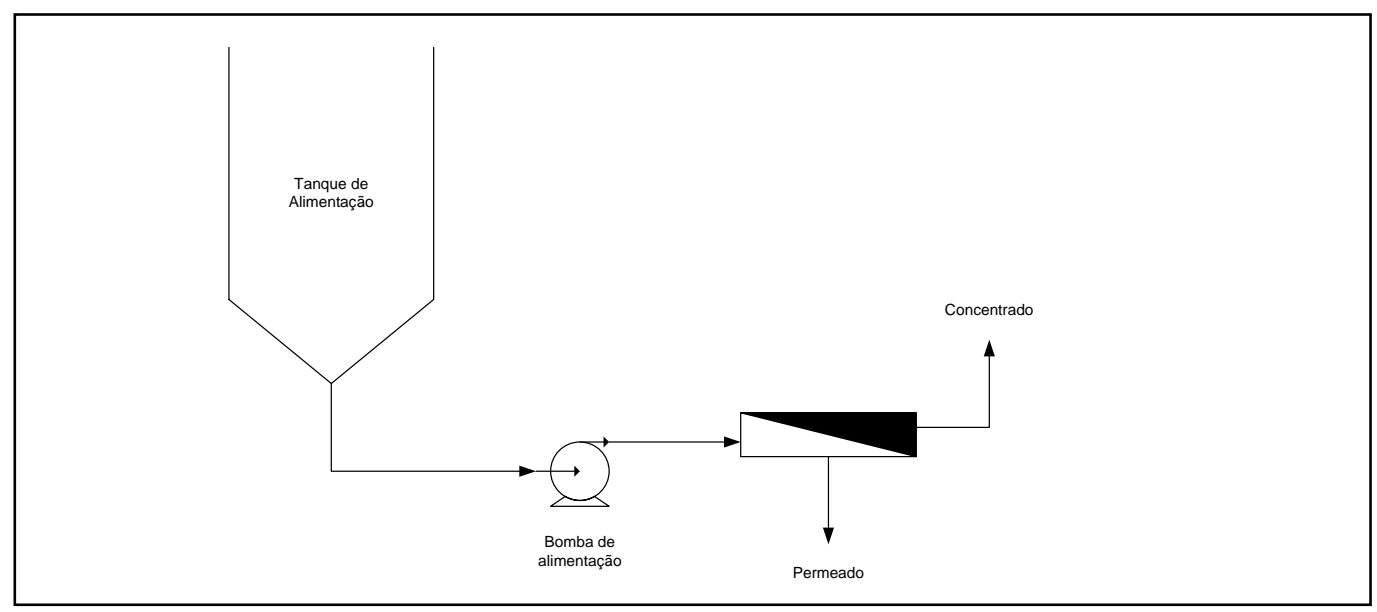

Figura 21 - Sistema com Passe único

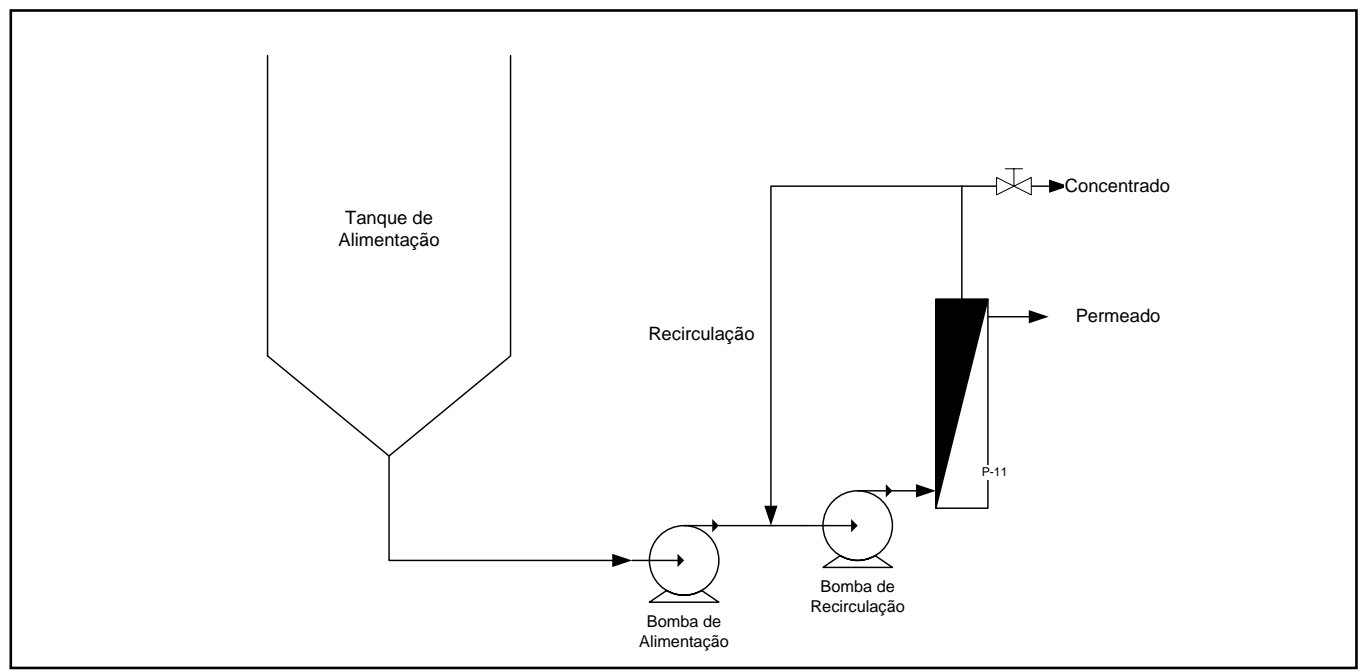

Figura 22- Sistema com recirculação

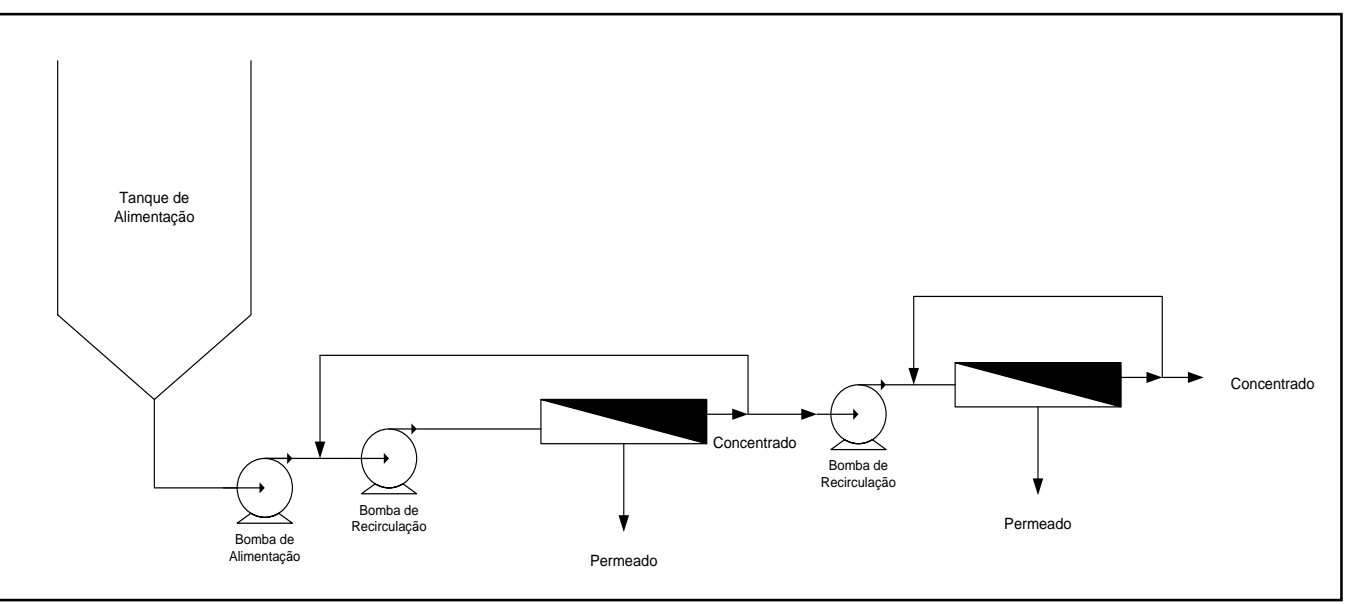

Figura 23- Sistema com Múltiplos Estágios 
A forma como é conduzido o fluxo do sistema tem interferência direta na concentração de contaminantes do rejeito e na taxa de recuperação de água, ou seja no rendimento da membrana.

Um sistema de membranas deve operar utilizando componentes que permitam controlar e monitorar pontos específicos do processo a fim de verificar se a operação está de acordo com o estabelecido ou se há necessidade de intervenção.

Para operar a unidade, além das membranas o sistema deve conter: unidade de prétratamento, sistema de bombeamento, válvulas, medidores de pressão, medidores de vazão, dispositivos de segurança capazes de interromper a operação para garantir a integridade dos componentes.

Para acompanhamento do sistema devem ser previstos componentes de medição e controle como: pressão e pressão diferencial, indicadores de temperatura, condutivímetros, phmetro, chave de nível, controladores lógicos programáveis.

\subsubsection{Limpeza e Sanitização}

Ainda que no projeto seja previsto um sistema de pré-tratamento eficiente e sejam adotadas práticas operacionais capazes de minimizar os efeitos ocasionados pelo aumento da concentração de contaminantes, próximos à superfície da membrana, a formação de depósitos e de biofilmes é inevitável, o que causa redução na eficiência global do sistema.

Alguns fatores podem ser utilizados como indicativos da necessidade de parada na operação do sistema para realização de limpeza e sanitização da membrana, bem como de equipamentos e acessórios que compõem a unidade de tratamento. De acordo com Schneider (2001) esses fatores são:

$\checkmark$ Redução do fluxo de permeado;

$\checkmark$ Aumento da perda de carga na membrana;

$\checkmark$ Deterioração da qualidade do permeado; 
A realização da limpeza proporciona a restauração do fluxo de permeado a valores próximos ao estabelecido com a membrana limpa.

De acordo com Cheryan (1998), estabelecer um procedimento de limpeza da membrana, além de prevenir a contaminação do permeado, influencia diretamente na questão econômica, pois é mais produtivo interromper a operação do sistema para restaurar o fluxo que operá-lo com fluxo reduzido.

Porém, as limpezas devem ser realizadas com muito critério, uma vez que podem reduzir significativamente a vida útil da membrana. Ainda de acordo com Cheryan (1998), é mais significativo especificar a vida útil da membrana em função dos ciclos de limpeza do que em termos de ciclos da operação.

Segundo Zeman e Zydney (1996), os depósitos podem ser removidos por mecanismos físicos, como retrolavagem (backflushing), que consiste na alternância da direção do fluxo de permeado após um período pré-estabelecido de operação do sistema, ou ainda, dado o aumento da velocidade da própria corrente de alimentação, o que gera um fluxo turbulento, promovendo o arraste do material que se encontra próximo à superfície da membrana e, conseqüentemente, limita a formação de depósitos e biofilme.

Um terceiro procedimento utilizado para remoção física de contaminantes presentes na superfície da membrana é a redução da pressão de alimentação, o que promove um relaxamento da membrana e, consequentemente o desprendimento de parte do material depositado na sua superfície. Zeman e Zydney (1996) e Cheryan (1998) recomendam esse procedimento no caso de depósitos que não estejam muito aderidos à superfície.

Segundo Judd (2006), quando não se utiliza produto químico, a limpeza física não agride de forma significativa a estrutura da membrana e, assim, não exige que o sistema tenha sua operação interrompida por longos períodos sendo, portanto, menos onerosa quando comparada à limpeza química.

Por outro lado, a limpeza química, muitas vezes, é inevitável e considerada como o método mais efetivo para remoção de incrustações. Esta pode ser realizada com um único produto ou uma combinação deles. 
Durante o processo de limpeza o agente químico desestabiliza a interação entre a membrana e o depósito, seja ele de origem orgânica ou inorgânica, promovendo o desprendimento do material aderido.

A escolha do produto mais adequado a ser utilizado no processo de limpeza, deve levar em consideração fatores como o tipo de sistema, as características do depósito a ser removido e, principalmente, o tipo de material que compõe a membrana (WAGNER, 2001), pois não deve haver incompatibilidade entre esse material e o agente de limpeza.

A tabela 14 apresenta o tipo de depósito e qual o produto mais recomendado para removê-lo.

Tabela 16 Características dos produtos utilizados na remoção de material específico

\begin{tabular}{ccccccc}
\hline \multirow{2}{*}{ CARACTERÍSTICA } & \multicolumn{5}{c}{ TIPO DE MATERIAL REMOVIDO DA SUPERFICIE DA MEMBRANA } \\
\cline { 2 - 6 } & Inorgânico & Orgânico & $\begin{array}{c}\text { Metais } \\
\text { Pesados }\end{array}$ & Biofilme & $\begin{array}{c}\text { Óleos e } \\
\text { graxas }\end{array}$ & Proteínas \\
\hline Ácido & $\checkmark$ & $\checkmark$ & & $\checkmark$ & $\checkmark$ \\
Álcali & & $\checkmark$ & & & & $\checkmark$ \\
Oxidante & & $\checkmark$ & & & $\checkmark$ & $\checkmark$ \\
Surfactante & $\checkmark$ & $\checkmark$ & & & & $\checkmark$ \\
Enzima & & $\checkmark$ & $\checkmark$ & & \\
Sanitizante & & & & &
\end{tabular}

Fonte: KOCHKLEEN (2010)

Conforme já explicitado, durante o processo de limpeza é possível utilizar um ou mais agentes, o que deve ser determinado em função da natureza do material depositado na superfície da membrana. Al-Obeidani et. al (2008), demonstram que a restauração do fluxo de permeado, em membrana de microfiltração, utilizada para tratar água do mar contaminada com óleo, é mais eficiente quando empregada limpeza alcalina precedida por limpeza ácida.

Para que se assegure a qualidade microbiológica do permeado faz-se necessária a sanitização não só das membranas, mas também de todos os componentes do sistema. Esse procedimento somente será eficiente se for precedido por limpeza química, pois a presença de depósitos na superfície da membrana pode proteger os microorganismos da ação do agente sanizante. 
De acordo com Cheryan (1998) para que o processo de limpeza e sanitização da membrana obtenha a máxima eficiência é necessário que se atente para alguns fatores:

$\checkmark$ Resistência da membrana e de outros componentes do sistema aos agentes de limpeza e sanitização utilizados;

$\checkmark$ É ideal que a solução de limpeza flua pelo sistema em condições hidráulicas que favoreçam o fluxo turbulento, ou seja, $n^{\circ}$ de Reynolds maior que 2100. Caso não haja possibilidade de atingir esse valor deve-se operar com alta velocidade linear, altas taxas de cisalhamento na junto à superfície da membrana, o que isso facilita a limpeza, condição na qual operam as membranas de MF e UF na configuração fibra oca;

$\checkmark$ Durante o processo de limpeza a pressão só deve ser elevada a valores compatíveis com a resistência da membrana, após a remoção dos sólidos presentes em sua superfície.

$\checkmark$ A contralavagem pode ser aplicada em membranas que possuam suporte, o que evita seu rompimento. Essa prática é efetiva na remoção de partículas, porém ineficiente na remoção de macromoléculas e substâncias dissolvidas, e não deve ser confundida com a contralavagem periódica realizada em algumas membranas com o objetivo de aumentar o fluxo;

$\checkmark$ A maioria dos produtos químicos completam sua ação entre 30 e sessenta minutos. Para soluções contendo cloro 30 minutos é considerado tempo ótimo;

$\checkmark$ A cada $10^{\circ} \mathrm{C}$ de aumento na temperatura a taxa de reação química dobra. Sendo assim, a temperatura da solução de limpeza deve ser a igual à máxima tolerável pela membrana;

$\checkmark$ Deve-se assegurar que o pH da solução de limpeza esteja dentro dos limites toleráveis pela membrana para não Ihe causar dano.

No caso de membranas poliméricas há uma elevação na restauração do fluxo quando o último enxágue do ciclo de limpeza é feito com uma solução alcalina.

No projeto de um sistema de separação por membranas deve estar previsto um subsistema de limpeza e sanitização composto por tanques para armazenagem das 
soluções, filtro, bombas, tubulação e válvulas. O volume dos agentes de limpeza e sanitização devem ser suficientes para preencher todos os componentes do sistema.

Caso a limpeza seja feita a uma temperatura superior à ambiente deve-se prever sistema de aquecimento.

Uma regra muito importante é nunca permitir que a membrana seque após entrar em contato com a corrente de alimentação. Após finalização do processo deve-se proceder imediatamente a enxágue de toda a planta de membrana, incluindo bombas, tanque, tubulações, filtros e demais componentes, com água limpa.

\subsubsection{Processos de Separação por Membranas utilizados na produção de água para Reúso}

$\mathrm{Na}$ atualidade, os problemas relacionados à escassez de água, principalmente em grandes centros urbanos, têm conduzido à busca por tecnologias avançadas para produção de água de reúso a partir de esgoto sanitário. De maneira geral, essas tecnologias visam à remoção de contaminantes específicos como: sólidos suspensos e dissolvidos, microorganismos e nutrientes.

As tecnologias disponíveis para o tratamento e adequação das águas residuárias abrangem um grande número de opções, sendo os processos de separação por membranas considerados elementos chaves para o tratamento avançado de esgoto sanitários visando o reúso de água (WINTGENS et al., 2005). Howell (2004) destaca que a tecnologia de separação por membranas pode contribuir de maneira significativa com a prática do reúso, pois é capaz de produzir água com qualidade superior quando comparada aos processos convencionais. Além disso, de acordo com Arevola et al. (2009), quando se trata de remoção de organismos patogênicos, essa tecnologia não gera subprodutos como aqueles formados durante o processo de desinfecção com cloro.

De acordo com Gandini et. al. (1996) um estudo desenvolvido na cidade de Sidney, Austrália, utilizando membrana de ultrafiltração na configuração fibra oca, com massa molecular de corte de $100.000 \mathrm{Da}$, avaliou o desempenho de um sistema de 
ultrafiltração como tratamento terciário do efluente proveniente de um reator biológico com biomassa aderida. A unidade piloto foi instalada na estação de tratamento de esgoto de Malabar recebendo o efluente secundário com o reator biológico operando com taxa de filtração de $0,7 \mathrm{~m} \cdot \mathrm{h}^{-1}$ e de $1,4 \mathrm{~m} \cdot \mathrm{h}^{-1}$.

Um resumo da eficiência do sistema em relação à remoção de contaminantes é apresentado na tabela 15.

Tabela 17 - Comparação da eficiência do sistema de ultrafiltração operando com efluente distintos

\begin{tabular}{|c|c|c|}
\hline Variáveis & $\begin{array}{l}\text { Bioreator operando } \\
\text { com taxa de } 0,7 \mathrm{~m} \cdot \mathrm{h}^{-1}\end{array}$ & $\begin{array}{l}\text { Bioreator operando } \\
\text { com taxa de } 1,4 \mathrm{~m} \cdot \mathrm{h}^{-1}\end{array}$ \\
\hline Sólidos Suspensos & 100 & 100 \\
\hline DBO & 81 & 72 \\
\hline DQO & 37 & 51 \\
\hline Carbono orgânico dissolvido & 30 & $*$ \\
\hline$U V_{254 \mathrm{~nm}}$ & 20 & 37 \\
\hline NKT & 30 & 5 \\
\hline $\mathrm{NH}_{3}$ & 33 & 11 \\
\hline
\end{tabular}

De acordo com o mesmo autor o esgoto sanitário submetido a um tratamento secundário seguido por processo de ultrafiltração pode se descartado em áreas sensíveis ou recreacionais sem qualquer tipo de risco.

Além da eficiência da ultrafiltração em relação à remoção de contaminantes, o estudo em questão teve como objetivo determinar as condições operacionais ótimas do sistema. Para isso a unidade foi alimentada, primeiramente, com o efluente do reator biológico operando a uma taxa de $0,7 \mathrm{~m} \cdot \mathrm{h}^{-1}$. Nesse caso, a qualidade do afluente permitiu sustentar um fluxo de permeados de $80 \mathrm{~L} . \mathrm{h}^{-1} \cdot \mathrm{m}^{-2}$ por período de dez dias e 90 L. $h^{-1} \cdot \mathrm{m}^{-2}$ por um período de cinco dias.

Outro ensaio realizado, agora com o reator biológico operando a uma taxa de 1,4 m.h-1 e a membrana com um fluxo de $0,7 \mathrm{~L} \cdot \mathrm{h}^{-1} \cdot \mathrm{m}^{-2}$, demonstrou que após três dias de operação a vazão de permeado sofreu uma redução de, aproximadamente, $80 \%$. Para a mesma condição de operação foi adicionado Carvão Ativado em Pó, como prétratamento, para a remoção de contaminantes específico que favorecem a ocorrência 
de depósitos orgânicos na superfície da membrana e, consequentemente, o crescimento do biofilme. Nesse caso a unidade piloto operou por seis dias, ou seja, dosando-se o carvão ativado o tempo de operação entre duas limpezas químicas é o dobro daquele correspondente ao sistema operando sem o carvão.

Tchobanoglous et. al. (1998) avaliaram a utilização de membrana de polissulfona de ultrafiltração, na configuração fibra oca, com peso molecular de corte de 100.000 Dalton, no tratamento terciário de esgoto municipal na cidade de Davis, Califórnia. Esse estudo utilizou dois tipos de efluentes: um secundário proveniente de um sistema de lodos ativados e um terciário proveniente de um processo de filtração ascendente. Os resultados do estudo em questão mostraram que o sistema de ultrafiltração apresentou eficiência em relação à remoção de DBO e DQO de $87,5 \%$ e 78,8\%, respectivamente. Para minimizar os problemas relacionados ao crescimento microbiológico na superfície da membrana, o sistema foi submetido a contralavagens, com frequência de 20 minutos, com solução de Hipoclorito de Sódios a uma concentração de 100 a 150 mg.L' ${ }^{1}$. De acordo com o mesmo autor a unidade piloto operou com, aproximadamente, $80 \%$ de recuperação de água.

Membranas de microfiltração e ultrafiltração aplicadas ao tratamento terciário de esgoto sanitário destinam-se à remoção de contaminantes como sólidos em suspensão, matéria orgânica e organismos patogênicos, conferindo à água produzida uma elevada qualidade com várias possibilidades de uso (WINTEGENS, 2005). Além dos contaminates citados, de acordo com Cheryan (1998) a membrana de ultarfitração tem capacidade de remover compostos com elevada massa molecular. Ainda de acordo com o mesmo autor pode-se citar dois exemplos de aplicação da tecnologia de separação por membranas utilizada para produzir água de reúso a partir de esgoto secundário:

$\checkmark$ Reúso de água no Parque Olímpico da Austrália: nesse local a demanda dos usos não potáveis é abastecida com água de reúso produzida a partir de esgoto secundário tratado por processo oxidativo utilizando radiação Ultravioleta, seguido por processo de microfitração. Trinta por cento do efluente desse processo é submetido ao tratamento por osmose reversa para manter a concentração de Sólidos Dissolvidos em torno de $500 \mathrm{mg}^{-\mathrm{L}^{-1}}$. Antes de ser 
distribuída a água de reúso é clorada e, para reduzir o risco do estabelecimento de conexões cruzadas essa água é distribuída através de tubulações com cor distinta daquelas que distribuem água potável.

$\checkmark$ Utilização de membranas para reúso de água em residências no Japão: os processos de separação por membranas são utilizados para produzir água de reúso a partir de águas cinza. Foi constatado que os processos de separação por membranas oferecem vantagens significativas quando comparados aos processos biológicos, principalmente quanto à eliminação de organismos patogênicos e à robustez do processo.

Manter constante a qualidade da água e evitar riscos à saúde dos usuários são questões de fundamental importância quando se trata da produção de água para reúso. De acordo com Gandini et. al. (1996) um estudo desenvolvido na cidade de Sidney, Austrália, utilizando membrana de ultrafiltração na configuração fibra oca, com peso molecular de corte de $100.000 \mathrm{Da}$, avaliou o desempenho de um sistema de ultrafiltração como tratamento terciário do efluente proveniente de um reator biológico com biomassa aderida. A unidade piloto foi instalada na estação de tratamento de esgoto de Malabar recebendo o efluente secundário com o reator biológico operando com taxa de filtração de $0,7 \mathrm{~m} \cdot \mathrm{h}^{-1}$ e de $1,4 \mathrm{~m} \cdot \mathrm{h}^{-1}$.

Um resumo da eficiência do sistema em relação à remoção de contaminantes é apresentado na tabela 16.

Tabela 18 - Comparação da eficiência do sistema de ultrafiltração operando com efluente distintos

\begin{tabular}{lcc}
\hline \multicolumn{1}{c}{ Variáveis } & $\begin{array}{c}\text { Bioreator operando } \\
\text { com taxa de } \mathbf{0 , 7} \mathbf{~ m} \cdot \mathbf{h}^{-\mathbf{1}}\end{array}$ & $\begin{array}{c}\text { Bioreator operando } \\
\text { com taxa de } \mathbf{1 , 4} \mathbf{~ m} \cdot \mathbf{h}^{-\mathbf{1}}\end{array}$ \\
\hline Sólidos Suspensos & 100 & 100 \\
DBO & 81 & 72 \\
DQO & 37 & 51 \\
Carbono orgânico dissolvido & 30 & $*$ \\
$\mathrm{UV}_{\mathbf{2 5 4} \mathbf{n m}}$ & 20 & 37 \\
$\mathrm{NKT}$ & 30 & 5 \\
$\mathrm{NH}_{3}$ & 33 & 11 \\
\hline
\end{tabular}


De acordo com o mesmo autor o esgoto sanitário submetido a um tratamento secundário seguido por processo de ultrafiltração pode se descartado em áreas sensíveis ou recreacionais sem qualquer tipo de risco.

Além da eficiência da ultrafiltração em relação à remoção de contaminantes, o estudo em questão teve como objetivo determinar as condições operacionais ótimas do sistema. Para isso a unidade foi alimentada, primeiramente, com o efluente do reator biológico operando a uma taxa de $0,7 \mathrm{~m} \cdot \mathrm{h}^{-}{ }^{1}$. Nesse caso, a qualidade do afluente permitiu sustentar um fluxo de permeados de 80 I.h. $\mathrm{m}^{-2}$ por período de dez dias e 90 I.h. $\mathrm{m}^{-2}$ por um período de cinco dias.

Outro ensaio realizado, agora com o reator biológico operando a uma taxa de 1,4 m.h- ${ }^{1}$ e a membrana com um fluxo de 70 I.h.m ${ }^{-2}$, demonstrou que após três dias de operação a vazão de permeado sofreu uma redução de, aproximadamente, $80 \%$. Para a mesma condição de operação foi adicionado Carvão Ativado em Pó como pré-tratamento com o objetivo de remover contaminantes específico que favorecem o crescimento do biofilme. Nesse caso a unidade piloto operou por seis dias, ou seja, dosando-se o carvão ativado o tempo de operação entre duas limpezas químicas é o dobro daquele correspondente ao sistema operando sem o carvão.

Tchobanoglous et. al. (1998) avaliaram a utilização de membrana de polissulfona de ultrafiltração, na configuração fibra oca, com peso molecular de corte de 100.000 Dalton, no tratamento terciário de esgoto municipal na cidade de Davis, Califórnia. Esse estudo utilizou dois tipos de efluentes: um secundário proveniente de um sistema de lodos ativados e um terciário proveniente de um processo de filtração ascendente. Os resultados do estudo em questão mostraram que o sistema de ultrafiltração apresentou eficiência em relação à remoção de DBO e DQO de $87,5 \%$ e 78,8\%, respectivamente. Para minimizar os problemas relacionados ao crescimento microbiológico na superfície da membrana, o sistema foi submetido a contralavagens, com frequência de 20 minutos, com solução de Hipoclorito de Sódios a uma concentração de 100 a 150 mg.L' ${ }^{1}$. De acordo com o mesmo autor a unidade piloto operou com, aproximadamente, $80 \%$ de recuperação de água. 
Um estudo desenvolvido na cidade da Califórnia - EUA, comparou o desempenho de um sistema de ultrafiltração tubular em Fluoreto de Polivinilideno-PVDF no tratamento de esgoto bruto e primário (RAVAZZINI, et al., 2005). Um resumo dos resultados relativos à qualidade do esgoto bruto e do permeado e à eficiência do sistema de ultrafiltração na remoção de contaminantes está apresentado na tabela 17

Tabela 19 - Qualidade do permeado produzido a partir de esgoto bruto e primário

\begin{tabular}{|c|c|c|c|c|c|c|c|}
\hline \multirow{2}{*}{ Variáveis } & \multirow{2}{*}{ Unid } & \multicolumn{2}{|c|}{$\begin{array}{l}\text { Qualidade do } \\
\text { Esgoto }\end{array}$} & \multicolumn{4}{|c|}{$\begin{array}{l}\text { Qualidade do Permeado produzido a } \\
\text { partir de : }\end{array}$} \\
\hline & & Bruto & Primário & $\begin{array}{c}\text { Esgoto } \\
\text { Bruto }\end{array}$ & $\begin{array}{c}\text { Eficiência } \\
\%\end{array}$ & $\begin{array}{l}\text { Esgoto } \\
\text { Primário }\end{array}$ & $\begin{array}{c}\text { Eficiência } \\
\%\end{array}$ \\
\hline Condutividade elétrica & $\mu \mathrm{S} . \mathrm{cm}^{-1}$ & 1340 & 1042 & 1240 & 7,5 & 1036 & 0,6 \\
\hline Turbidez & NTU & 110 & 55 & 0,15 & 99,9 & 0,02 & 100,0 \\
\hline Sólidos Suspensos Totais & $\mathrm{mg} \cdot \mathrm{L}^{-1}$ & 63 & 18 & 0 & 100,0 & 0 & 100,0 \\
\hline DQO & $\mathrm{mg} \cdot \mathrm{L}^{-1}$ & 218 & 135 & 138 & 36,7 & 78 & 42,2 \\
\hline Nitrogênio Total & $\mathrm{mg} \cdot \mathrm{L}^{-1}$ & 38 & 30 & 29 & 23,7 & 28 & 6,7 \\
\hline Fósforo Total & $m g \cdot L^{-1}$ & 5,4 & 5 & 4,4 & 18,5 & 4,1 & 18,0 \\
\hline Nitrato & $\mathrm{mg} \cdot \mathrm{L}^{-1}$ & 38,4 & 29,9 & 39,4 & $-2,6$ & 30,3 & $-1,3$ \\
\hline Fosfato & $\mathrm{mg} \cdot \mathrm{L}^{-1}$ & 4,1 & 3,6 & 4 & 2,4 & 3,4 & 5,6 \\
\hline
\end{tabular}

Com base nos resultados da tabela 17 é possível afirmar que a membrana de ultrafiltração apresenta elevada eficiência com relação à remoção de turbidez e sólidos em suspensão. Porém, com relação a nutrientes e condutividade elétrica a eficiência de remoção não foi expressiva.

Gómes et. al. (2007) realizaram um estudo comparativo entre o tratamento terciário de esgoto por dois processos distintos: Ultrafiltração com membrana de fluoreto de polivinilideno e diâmetro de poro de 0,05 $\mu \mathrm{m}$ e processo Físico-químico seguido de oxidação por Ultravioleta (UV). De acordo com o mesmo autor uma das vantagens relacionadas ao processo de separação por membranas é que a qualidade microbiológica da água produzida é constante, independe da qualidade do afluente, fato que não foi constatado no sistema de Ultravioleta precedido de processo físico-químico. 
$\mathrm{Na}$ tabela 18 estão apresentados os resultados das análises qualitativas dos efluentes envolvidos no estudo.

Tabela 20 - Qualidade dos efluentes produzidos pelos dois sistemas

\begin{tabular}{ccccc}
\hline Variáveis & Und & $\begin{array}{c}\text { Esgoto } \\
\text { tratado }\end{array}$ & $\begin{array}{c}\text { Físico- } \\
\text { químico } \\
\text { seguido de } \\
\text { UV }\end{array}$ & Ultrafiltração \\
\hline Turbidez & NTU & $4-20$ & $0-0,5$ & $0-0,9$ \\
\hline $\begin{array}{c}\text { Sólidos Suspensos } \\
\text { Totais }\end{array}$ & $\mathrm{mg} \cdot \mathrm{L}^{-1}$ & $11-87$ & $1-9$ & $1-7$ \\
\hline${\mathrm{T}-U V_{254}}_{\text {Coliformes }}$ & $\%$ & $11-41$ & $37-76$ & - \\
\hline Termotolerantes & $\left(\mathrm{NMP} .100 \mathrm{ml}^{-1}\right)$ & $27000-$ & $0-1000$ & $0-9$ \\
\hline
\end{tabular}

Ainda no estudo de Gómes et. al. (2007), uma análise econômica mostrou que as duas tecnologias apresentam custos variáveis similares. Porém, o custo de investimento associado aos sistemas de membranas é duas vezes maior do que aqueles relativos à instalação do sistema de UV precedido por processo físico-químico. No caso do sistema de ultrafiltração os custos operacionais envolvido são aqueles associados a consumo energético e consumo de produtos utilizados nas limpezas químicas. Já no processo de tratamento por UV precedido por físico-químico os custos operacionais relacionam-se a consumo de energia e produto químico de uso constate e tratamento e disposição de lodo.

Arévalo et al. (2009) avaliaram a qualidade do esgoto sanitário tratado por dois sistemas de membranas para reúso urbano. Os autores utilizaram um sistema de membranas de Ultrafiltração após um sistema convencional de lodos ativados e um sistema MBR, tecnologia que associa, no caso, membranas de ultrafiltração a sistemas biológicos para o tratamento de esgoto. Os resultados reportados pelos mesmos autores demonstraram que os dois sistemas produziram água com características físico-químicas similares, embora o sistema MBR tenha sido mais eficiente na redução de DQO. No entanto, a cor do efluente produzido pelo sistema MBR foi mais elevada. 
Um resumo da qualidade do efluente produzido pelos dois sistemas é apresentado na Tabela 19.

Tabela 21: Qualidade do efluente produzido pelo sistema MBR e ultrafiltração terciária.

\begin{tabular}{lcc}
\hline \multirow{2}{*}{ Parâmetro } & \multicolumn{2}{c}{ Efluente Tratado } \\
\cline { 2 - 3 } & MBR & Ultrafiltração terciária \\
\hline Turbidez (NTU) & 0,12 & 0,15 \\
SST $\left(\mathrm{mg} \cdot \mathrm{L}^{-1}\right)$ & 0,76 & 1,2 \\
Cor $(436 \mathrm{~nm}) \mathrm{m}-1$ & 1,8 & 0,55 \\
DQO $\left(\mathrm{mg} \cdot \mathrm{L}^{-1}\right)$ & 50,5 & 75 \\
Coliformes Termotolerantes (NMP.100 $\left.\mathrm{ml}^{-1}\right)$ & 35 & 1,4 \\
E. coli & 3,5 & 0 \\
Coliphages & 0 & 0,3 \\
\hline
\end{tabular}

Fonte: Arévalo et al. (2009)

Um aspecto de grande relevância observado por Arévalo et al. (2009) refere-se à elevada capacidade de desinfecção do sistema de ultrafiltração precedido de lodos ativados. Na tabela 19 é possível observar a remoção completa de E. coli por esse sistema, o qual se mostra superior se comparado ao sistema de MBR.

No caso de reúso em sistemas aeroportuários, por se tratar de um caso específico, há uma limitação de dados disponíveis em literatura. Um estudo disponível, desenvolvido para esse tipo de empreendimento, avaliou o tratamento do esgoto gerado no aeroporto internacional de Qingdao, China utilizando membrana de ultrafiltração associada a um tratamento biológico Liu et. al. (2007). Dentre outras variáveis foram monitoradas $\mathrm{pH}$, Sólidos em suspensão, DQO e DBO. Com relação às três últimas os resultados da pesquisa mostraram grande eficiência do sistema com relação à remoção de contaminantes, conforme apresentado na tabela 19.

A tabela 20 mostra a qualidade do afluente e do efluente, e a eficiência do sistema em relação à remoção de DBO, DQO e Sólidos em Suspensão. 
Tabela 22 - Qualidade do Efluente e do Afluente do Sistema de tratamento

\begin{tabular}{llccc}
\hline \multicolumn{1}{c}{ Variáveis } & Und & Afluente & Efluente & Eficiência do tratamento \% \\
\hline $\mathrm{pH}$ & & 7,6 & 6,9 & $* *$ \\
\hline Sólido em suspensão & $\mathrm{mg} \cdot \mathrm{L}^{-1}$ & 160 & 4 & 97,50 \\
\hline DQO & $\mathrm{mg} \cdot \mathrm{L}^{-1}$ & 208 & 17 & 91,83 \\
\hline DBO & $\mathrm{mg} \cdot \mathrm{L}^{-1}$ & 102 & 5,2 & 94,90 \\
\hline
\end{tabular}

Os resultados obtidos indicaram que a qualidade da água produzida pelo sistema foi superior àquela exigida por diversos usos. Sendo assim, essa água pode ser utilizada com segurança para atender à demandas como irrigação de áreas verdes, reserva para combate a incêndio, usos paisagísticos e descargas em bacias sanitárias (LIU et. al. 2007).

A aplicação dos processos de separação por membranas visando o reúso não se restringem apenas ao tratamento de esgotos sanitários. Várias aplicações têm sido relatadas para adequação e reutilização de água em regiões urbanas. Nesse sentido, Hamada e Miyazaki (2004) realizaram estudos em escala de bancada para avaliar o tratamento de efluentes da lavagem de veículos utilizando membranas de fibra oca de UF de Peso Molecular de Corte de 150.000 Dalton, onde após tratamento o efluente produzido possuía uma Turbidez inferior a 0,05 uT e DQO de $15 \mathrm{mg} / \mathrm{L}$.

Apesar dos processos de separação por membranas exercerem um papel vital no reúso de água em regiões urbanas, Fane (2007) ressalta que a redução dos custos de investimento e operação associados com dados de operação de longo prazo são fundamentais para a inserção da tecnologia no conceito de sustentabilidade. 


\section{4-MATERIAIS E MÉTODOS}

\subsection{Características do processo biológico do AISP}

Todas as informações relativas às características da estação de tratamento de efluentes existente no aeroporto, relatadas a seguir, foram disponibilizadas pela INFRAERO através documentos que não são de domínio público, considerando-se restrições relativas à segurança do aeroporto.

O esgoto gerado no AISP é tratado no próprio local e, após adequação aos padrões estabelecidos no artigo 18 do decreto 8.468 de oito de setembro de 1976, é descartado no rio Baquirivu, passando inicialmente por dois espelhos d'água. As figuras 24 e 25 apresentam, respectivamente, uma vista aérea o um esquema simplificado da estação de esgotamento sanitário do AISP.

Considerando-se o diagrama da Figura 25, o esgoto gerado no AISP é submetido inicialmente a um processo de remoção de sólidos grosseiros e posteriormente é conduzido a um sistema centralizado de tratamento, que utiliza o processo de lodos ativados por aeração prolongada para estabilização da matéria orgânica. 


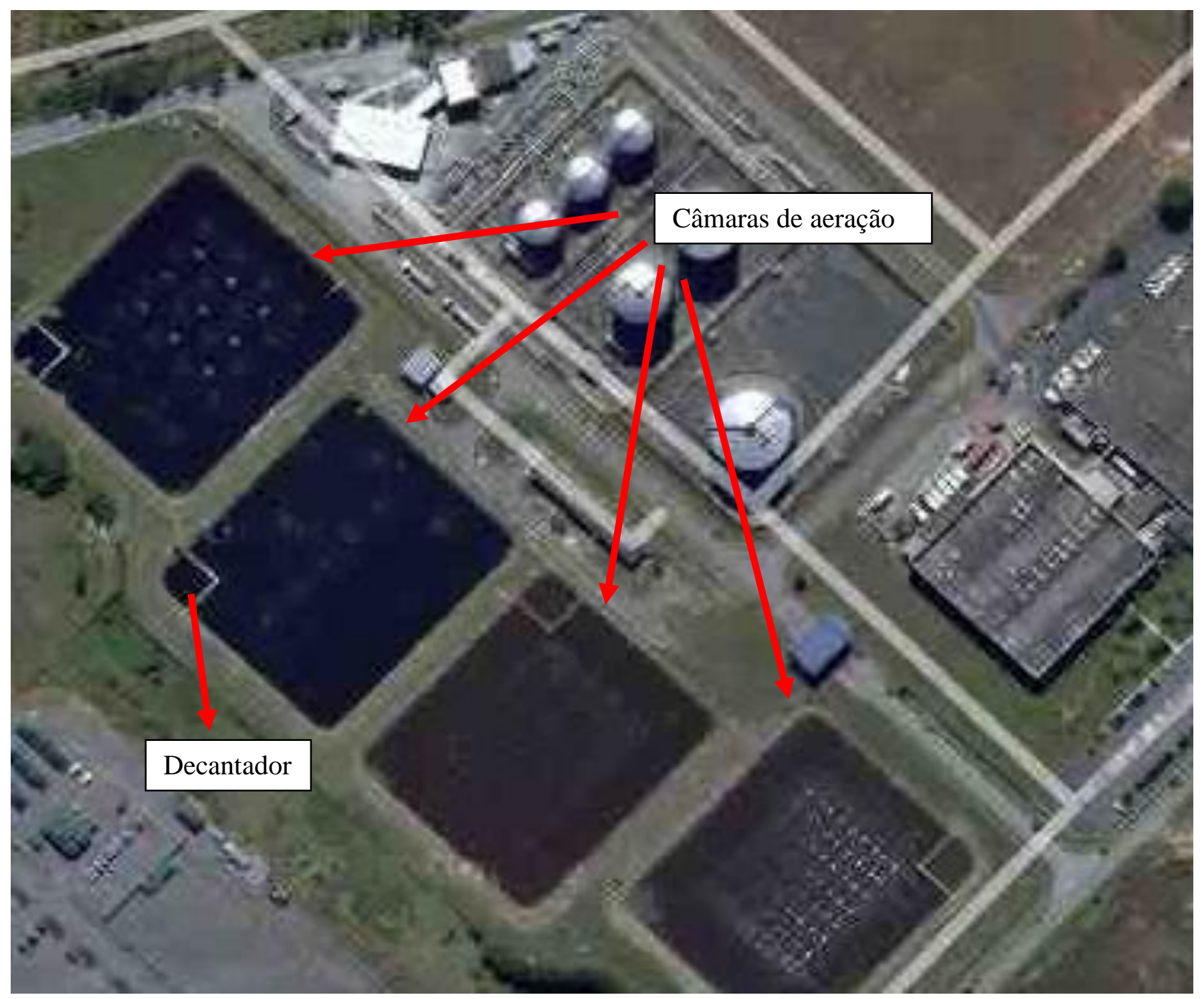

Figura 24 - Estação de tratamento de esgoto sanitário do Aeroporto Internacional de São Paulo 


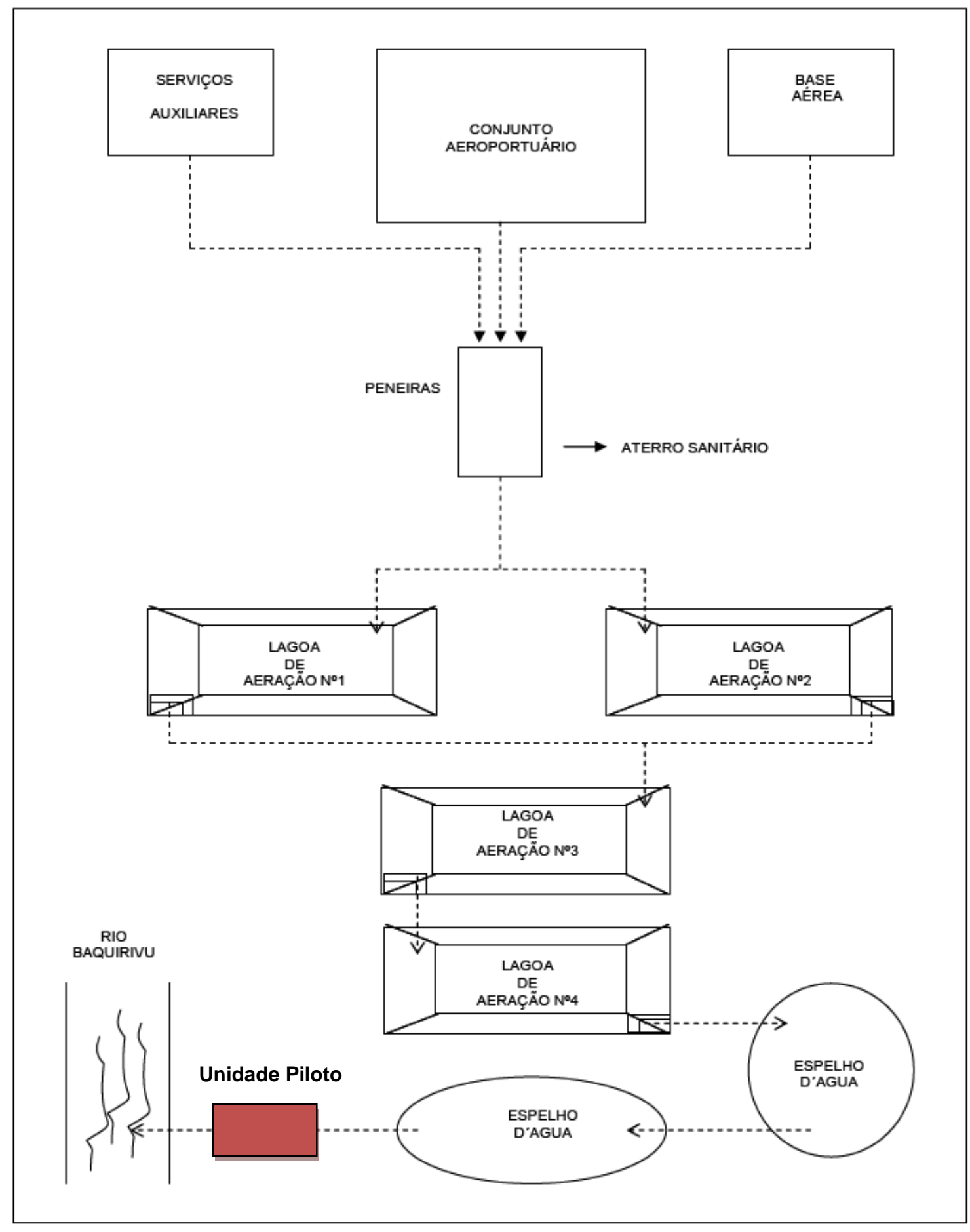

Figura 25 - Esquema do sistema de tratamento do efluente aeroportuário do AISP 
Os efluentes provindos das câmaras de aeração 1 e 2 são direcionados à câmara 3 onde recebe nova aeração promovida por 60 aeradores helicoidais. $\mathrm{Na}$ seqüência os efluentes passam para a câmara de aeração 4 , onde recebem aeração promovida por 20 aeradores helicoidais.

Após o tratamento nas câmaras de aeração, o efluente é encaminhado a outras duas lagoas que, a principio, foram construídas para regularização de vazão. Para o desenvolvimento deste projeto de pesquisa, entre a segunda lagoa e o ponto de descarte do efluente no Rio Baquirivu foi instalada a unidade piloto de ultrafiltração para subsidiar o estudo de avaliação do potencial de reúso de água a partir do esgoto gerado no AISP, conforme ilustra a figura 25.

\subsection{Unidade piloto de Ultrafiltração}

Os componentes que fazem parte da unidade piloto são:

1 - Cartucho de membranas do tipo Fibra Oca - CTG, 5" HF 66-45-XM50P da Koch Membrane Systems (USA);

2- Bomba de circulação do tipo centrífuga, vazão $15 \mathrm{~m}^{3} \cdot \mathrm{h}^{-1}, 45 \mathrm{psi}$, Fofo da marca KSB;

3 - Bomba de retrolavagem do tipo centrífuga, vazão $5 \mathrm{~m}^{3} \cdot \mathrm{h}^{-1}, 35 \mathrm{psi}$, Fofo marca KSB;

4 - Manômetros glicerinados, de 0 a 100 psi, marca Efluentes, instalados em diversos pontos do sistema;

5 - Termômetro glicerinado, de 0 a $100{ }^{\circ} \mathrm{C}$, marca Efluentes, instalado na linha de concentrado;

6 - Termostato (TT-01) com faixa de atuação entre 0 a $100{ }^{\circ} \mathrm{C}$, marca Danfoss, instalado na linha de alimentação.

7 - Filtro do tipo cartucho, com carcaça em polipropileno, capacidade de até $2 \mathrm{~m}^{3} \cdot \mathrm{h}^{-1} \mathrm{e}$ $300 \mathrm{kPa}$, precedendo o reservatório de água bruta;

8 - Filtros do tipo "Bag"de $50 \mu \mathrm{m}$, em Aço carbono, com tampa superior para carregamento e descarregamento de elemento filtrante e bocais de entrada e saída. Capacidade de até $18 \mathrm{~m}^{3} \cdot \mathrm{h}^{-1}$ e 3,5 bar. 
9 - Reservatório para solução de limpeza em polipropileno, com 300 L de volume útil e fundo plano;

10 - Reservatório para permeado em Polipropileno, com $500 \mathrm{~L}$ de volume útil e fundo plano;

11 - Reservatório para Hipoclorito de Sódio em polietileno, com $50 \mathrm{~L}$ de volume útil e fundo plano.

12 - Reservatório para armazenar água bruta em polipropileno, com $500 \mathrm{~L}$ de volume útil, fundo cônico e dreno de fundo;

13 - Painel elétrico (Quadro de Comando de Motores) composto por caixa Taunus, contendo componentes Schneider, PLC Schneider, botoeira na porta frontal para o controle dos processos.

14 - Controladores de nível tipo bóia em polipropileno com contatos seco SPDT e cabo elétrico instalados nos reservatórios de permeado, de solução de limpeza e de água bruta;

15 - Válvulas acionadas eletricamente, em Fofo, em diâmetros variáveis, com saídas para intercomunicação com o PLC Schneider;

16 - Válvulas manuais de diversos tipos ( diafragma, atuada, retenção, esférica, alívio e solenóide ), em material polimérico PP/PVC e (ou) metálicas em Fofo, com diâmetros variados;

17 - Tubos e conexões em polipropileno, com diâmetros variando entre 1/2 " e 2";

As especificações da membrana utilizada na unidade piloto (figura 26) são apresentadas na tabela 21 e no anexo 1. 


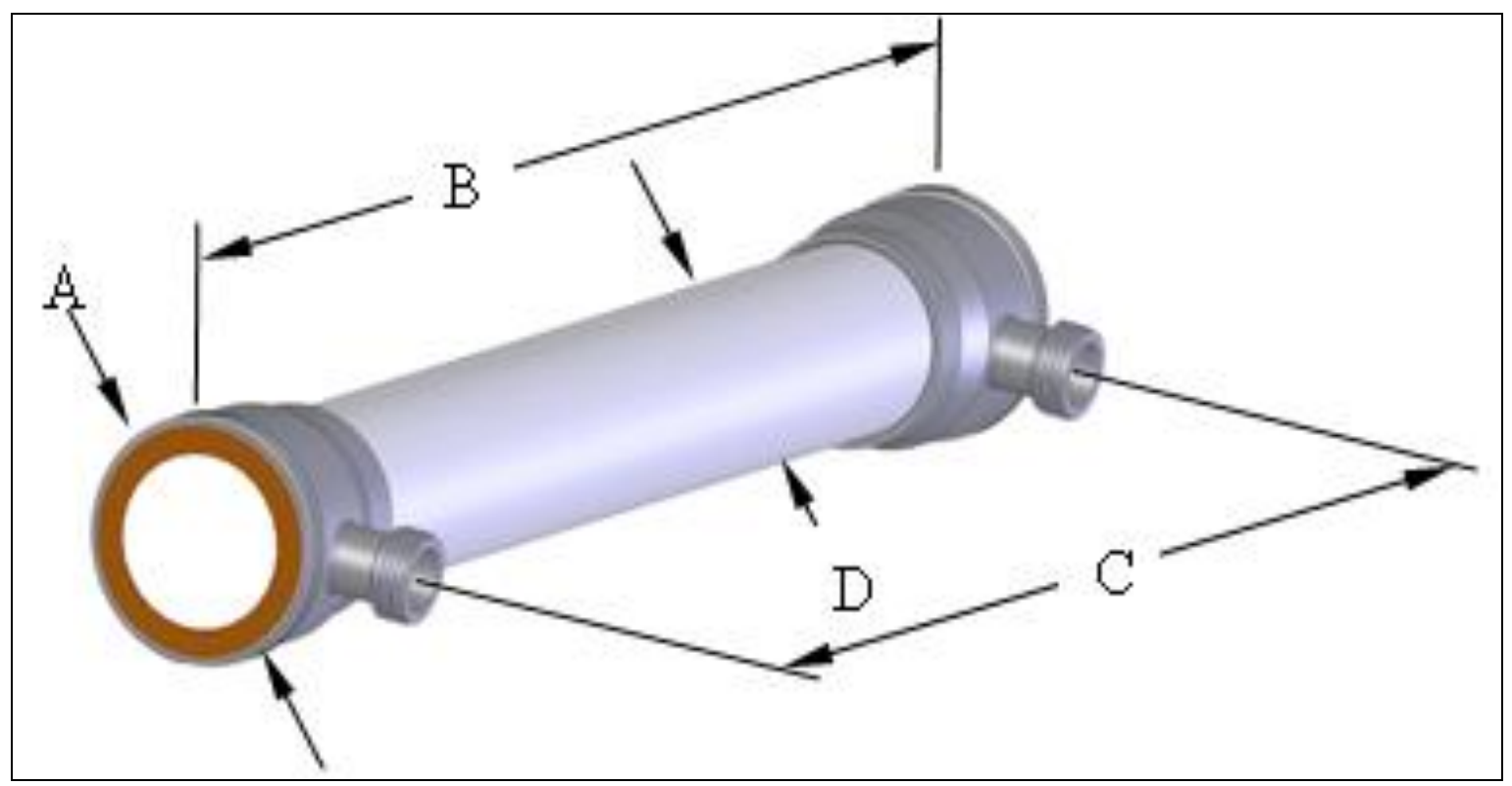

Figura 26- Módulo de membrana de fibra oca

Tabela 23 - Características das membranas

\begin{tabular}{lcc}
\hline Membrana de Ultrafiltração & Unidade & Características \\
\hline Modelo & & HF 5043-66-45-XM50P \\
Dimensões & $(\mathrm{cm})$ & $\mathrm{A}=15,2 ; \mathrm{B}=109,2 ; \mathrm{C}=98,1 ; \mathrm{D}=12,2$ \\
Área superficial & $\left(\mathrm{m}^{2}\right)$ & 6,1 \\
Peso molecular de corte & $(\mathrm{Dalton})$ & 50.000 \\
Vazão da membrana limpa & $\left(\mathrm{l} / \mathrm{h} / \mathrm{m}^{2}\right)$ & 82 \\
Pressão máxima de alimentação & $(\mathrm{bar})$ & 2,1 \\
Pressão Transmembrana & $(\mathrm{bar})$ & 2,1 \\
Pressão máxima na saída do permeado & $($ bar $)$ & 1,4 \\
alimentação & & 1,7 \\
Perda de carga máxima na membrana & $($ bar $)$ & $1,5-13$ \\
pH de operação & & \\
\hline
\end{tabular}

A figura 27 ilustra o local de instalação da unidade piloto e um esquema simplificado contendo os principais componentes da unidade é apresentado na figura 28. 


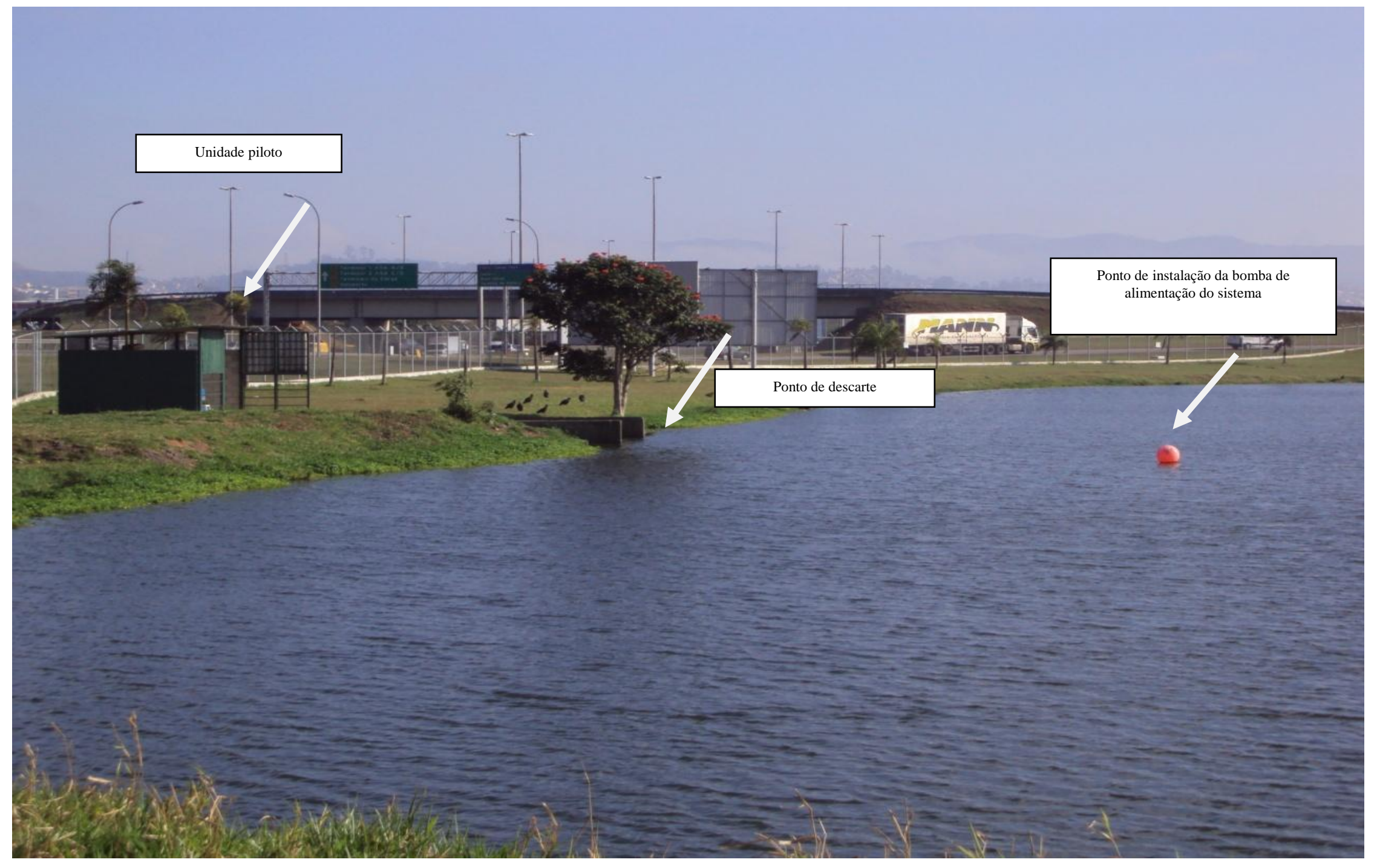

Figura 27- Local de instalação da unidade piloto de membrana 


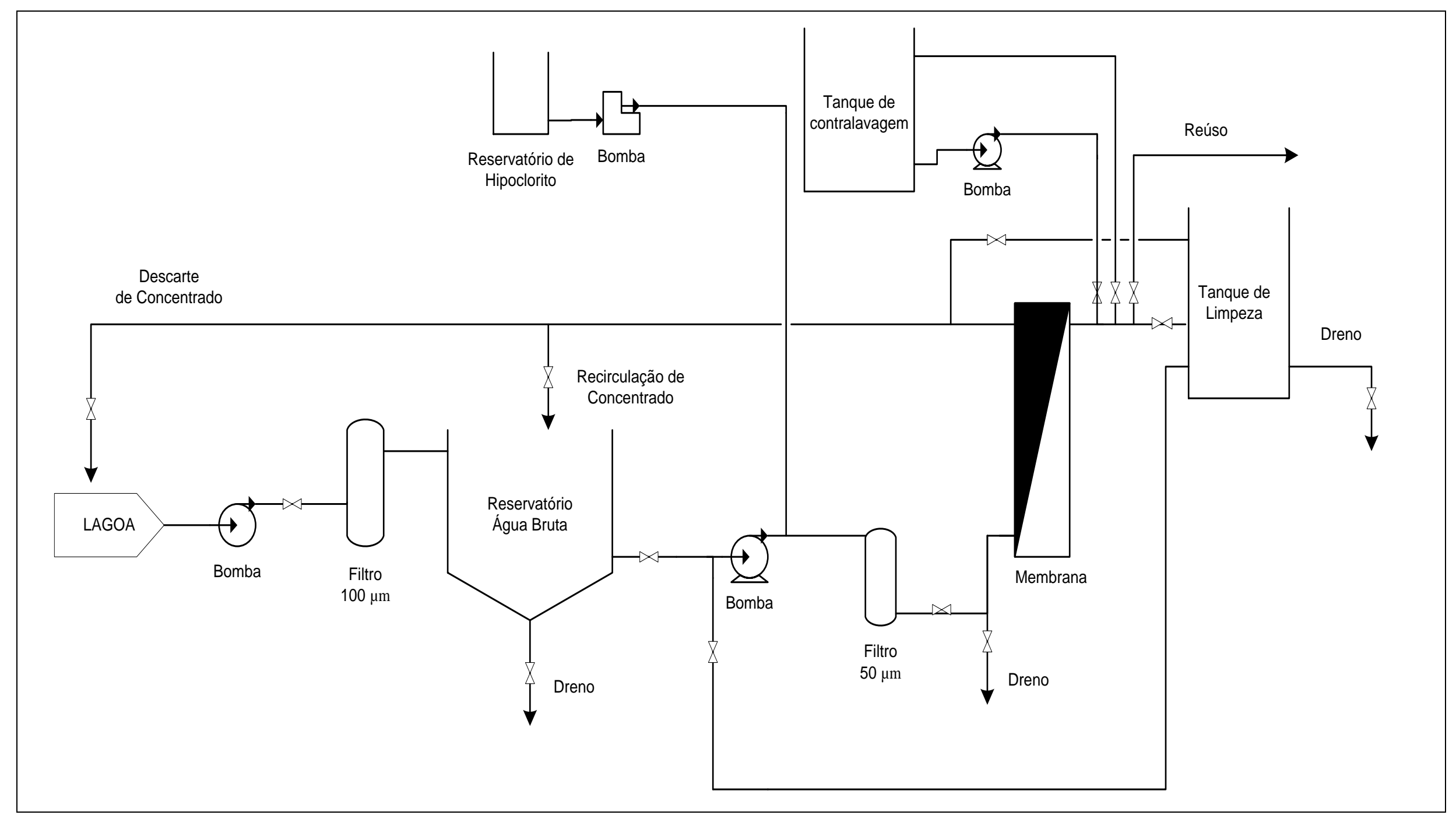

Figura 28- Fluxograma de processo da unidade piloto de membranas 
A unidade piloto operou de forma contínua sendo alimentada por uma bomba submersível instalada a, aproximadamente, $15 \mathrm{~m}$ de distância da margem da lagoa e $0,8 \mathrm{~m}$ de profundidade, funcionando de forma intermitente, com uma vazão $1600 \mathrm{~L}^{\mathrm{h}} \mathrm{h}^{-1}$. Um filtro de $100 \mu \mathrm{m}$, instalado na entrada do sistema, promoveu a separação parcial de sólidos do afluente, o qual era encaminhado ao reservatório de água bruta e, posteriormente, conduzido à membrana através da bomba centrífuga. Na figura 28 pode ser observada a existência de um dreno de fundo no reservatório de água bruta, o qual era acionado por uma válvula solenoide, com frequência de 40 minutos, para eliminar sólidos sedimentáveis. A parcela de água que não transpunha a membrana, cerca de $90 \%$ da vazão de alimentação, retornava ao reservatório de água bruta com o objetivo de aumentar a recuperação do sistema.

Um filtro de $50 \mu \mathrm{m}$ foi instalado com o objetivo de remover os sólidos remanescentes, porém, iniciados os testes, esse filtro foi removido devido à necessidade de substituição do meio filtrante em, aproximadamente, 30 horas de operação. Cabe ressaltar que essa medida não prejudicou o funcionamento da membrana.

A unidade piloto contou ainda com um reservatório para preparo da solução de limpeza e outro para armazenar o permeado a ser utilizado nas contralavagens promovidas sistema.

Devido ao fato sistemas de separação por membranas corresponderem a uma tecnologia relativamente nova, principalmente nos países em desenvolvimento, é de extrema importância a realização de ensaios piloto para o estabelecimento de parâmetros operacionais que proporcionem a máxima eficiência desses sistemas.

\subsection{Descrição do experimento}

A pesquisa em questão teve início com a identificação dos usos preponderantes e da demanda de água não potável existentes no AISP. Com base em dados bibliográficos relativos à qualidade da água exigida pelos usos identificados foi possível estabelecer as características qualitativas da água de reúso para atendê-los com segurança. 
Nessas condições optou-se por avaliar a viabilidade técnica de separação pelo sistema de membranas de ultrafiltração na configuração fibra oca, através da utilização de uma unidade piloto para tratar o efluente proveniente do Sistema de Esgotamento Sanitário existente no AISP.

A unidade piloto operou de modo cros-flow, de forma intermitente entre setembro de 2011 e janeiro de 2012 devido à necessidade de ajustes no sistema, relativos a problemas hidráulicos e de automação. Nesse período foi realizada uma campanha de amostragem para caracterização da eficiência do sistema em relação à remoção de contaminantes.

Finalizada a etapa de ajustes, a operação contínua teve início e foi mantida por três meses, com interrupções para realização de limpeza química e retrolavagem. As variáveis utilizadas para avaliar eficiência do sistema em relação à remoção de contaminantes e aquelas relacionadas à operação do sistema estão apresentadas nos quadros 1 e 2.

Quadro 1 - Variáveis utilizadas para avaliar a eficiência da membrana em relação à remoção de contaminantes

\begin{tabular}{c}
\hline VARIÁVEIS DE QUALIDADE \\
\hline Cor \\
pH \\
Turbidez \\
Condutividade Elétrica \\
DBO \\
DQO \\
Carbono Orgânico Dissolvido (COD) \\
Alcalinidade \\
Óleos e Graxas \\
Absorbância em Radiação Ultravioleta \\
$\left(\mathrm{UV}_{254} \mathrm{~nm}\right)$ \\
\hline
\end{tabular}


Quadros 2 - Variáveis operacionais consideradas no estudo

\begin{tabular}{c}
\hline Variáveis operacionais analisadas \\
\hline Pressão na entrada da membrana \\
Pressão na saída da membrana \\
Temperatura na entrada da membrana \\
Vazão de permeado \\
Vazão de recirculação \\
\hline
\end{tabular}

As coletas e análises realizadas no período citado foram feitas pela empresa EP Analítica de acordo com os padrões estabelecidos no Standard Methods for the Examination of Water and Wastewater, 1999.

As variáveis operacionais foram monitoradas por meio de um PLC e um programa computacional da marca Schneider, através dos quais, ao final do ensaio, foram estabelecidos parâmetros operacionais relativos à pressão de operação, à frequência de contralavagem e à limpeza química

Durante o período de operação foram realizadas limpezas químicas de acordo com as especificações do fornecedor:

$\checkmark$ Enxágue do sistema com aproximadamente 50 litros de permeado armazenado no tanque de limpeza;

$\checkmark$ Recirculação por trinta minutos com solução de detergente e pH próximo de 12 obtido através da dosagem de $\mathrm{NaOH}$ e medido por meio de pHmetro;

$\checkmark$ Enxágue do sistema com aproximadamente 50 litros de permeado.

$\checkmark$ Recirculação por 30 minutos com solução de cloro (100 ppm) e pH próximo de 12 obtido através da dosagem de $\mathrm{NaOH}$ e medido por meio de pHmetro;

$\checkmark$ Enxágüe de todo do sistema com aproximadamente 50 litros de permeado;

$\checkmark$ Reinício da operação. 


\subsection{Metodologia utilizada para o desenvolvimento da pesquisa}

\subsubsection{Identificação dos usos preponderantes de água no Aeroporto Internacional de São Paulo}

Para identificação do uso da água e geração de efluentes no AISP foi feito um levantamento utilizando as etapas de reúso que compõem a metodologia apresentada no diagrama da figura 2, página 24. Esse levantamento foi feito com base em documentos disponibilizados pela INFRAERO e em visitas de campo e, com base nele, foi possível identificar os diferentes usos não potáveis da água e a demanda relativa a cada um deles.

\subsubsection{Caracterização do efluente gerado no AISP}

A caracterização do efluente gerado no AISP foi feita com base em dois laudos de qualidade da água tratada disponibilizados pela INFRAERO e um laudo contemplando as variáveis estabelecidas pelo CONAMA 357/05. Além disso, durante o desenvolvimento da pesquisa, foram realizadas quatorze análises pela empresa EP Analítica contemplando as seguintes variáveis: Cor, pH, Turbidez, Condutividade elétrica, Alcalinidade, Carbono Orgânico Dissolvido, Óleos e Graxas, DBO, DQO, Coliformes Termotolerantes e Absorbância em $U_{254}$.

\subsubsection{Estabelecimento das características da água de reúso}

Devido à ausência, na literatura especializada, de diretrizes para reúso de água em aeroportos e a necessidade de se estabelecer padrões restritivos para a água de reúso nesses locais, no que se refere à presença de organismos patogênicos, garantindo com isso a saúde do usuário, foram adotados os padrões estabelecidos pela EPA (Asano, 2007) para usos urbanos como: descargas em sanitários e mictórios, irrigação de áreas verdes, limpeza de pisos e pátios, conforme tabela 4, página 28.

Já para água de reúso destinada à reposição em torres de resfriamento foram adotados os padrões apresentados na tabela 5, página 29. 


\subsubsection{Caracterização qualitativa da água produzida pelo sistema}

Mesmo com a operação intermitente no período referido foi possível realizar uma campanha de amostragem, composta por nove coletas, para caracterização da eficiência do sistema em relação à remoção de contaminantes. As amostras foram coletadas em quatro pontos distintos: entrada do sistema, saída do filtro, saída da membrana e na linha de recirculação.

Durante a operação contínua da unidade por três meses, foi feita uma nova campanha de amostragem, sendo realizada a coleta de mais quatros coletas para caracterização da água produzida pelo sistema de membranas.

Para a caracterização da água produzida pelo sistema em relação à concentração de sólidos dissolvidos, parâmetro contemplado na tabela 5 da página 29 , foi utilizada a análise de condutividade elétrica, a qual também indica a presença de substâncias iônicas, mas pode ser realizada de forma mais rápida e simples se comparada à análise de sólidos dissolvidos. Sendo assim, no estudo em questão para que a análise de condutividade pudesse substituir a de sólidos dissolvidos foi estabelecida uma relação numérica entre as duas variáveis que, para o caso específico do efluente gerado no AISP é de 0,7 .

\subsubsection{Definição de parâmetros operacionais}

Os ensaios relativos à definição de parâmetros operacionais foram realizados em três etapas distintas

1) Etapa 1 - Definição da pressão de operação: a unidade piloto operou com cinco valores distintos de pressão $(0,75 ; 1,0 ; 1,2 ; 1,4 ;$ e 1,6 bar $)$ por um período de 48 horas com cada um dos valores estabelecidos. Ao final de cada um dos testes foi contabilizado o volume de permeado produzido.

Antes do início de cada um dos testes o sistema foi submetido à limpeza química e sanitização.

2) Etapa 2 - Definição da frequência de retrolavagem: a unidade piloto operou com três frequências de retrolavagem (30, 45 e $60 \mathrm{~min}$ ) por 120 horas com cada 
frequência. Ao final de cada um dos testes foi contabilizado o volume efetivo de permeado produzido (descontando-se o volume gasto nas retrolavagens).

Antes do início de cada um dos testes o sistema foi submetido à limpeza química e sanitização.

3) Etapa 3 - Definição da frequência de limpeza química: o sistema operou com a pressão e frequência de contralavagens estabelecidas nas etapas 1 e 2, por aproximadamente $300 \mathrm{~h}$ com monitoramento das variações de fluxo de permeado e de pressão. A operação do sistema foi interrompida quando se observou uma queda acentuada e contínua no fluxo de permeado, indicando a necessidade de limpeza química. 


\section{RESULTADOS E DISCUSSÃO}

\subsection{Avaliação da demanda de água no AISP}

Através do levantamento realizado com base nos documentos disponibilizados pela INFRAERO e em visitas de campo foi possível identificar os usos preponderantes da água no AISP, os quais são apresentados na tabela 22

Tabela 24 - Consumo de água não potável no AISP

\begin{tabular}{lcc}
\hline \multicolumn{1}{c}{ Usos da Água } & $\begin{array}{c}\text { Consumo } \\
\text { (m3/mês) }\end{array}$ & $\begin{array}{c}\text { Consumo } \\
\text { (\%) }\end{array}$ \\
\hline Descarga em bacias sanitárias & 25.469 & 51 \\
Sistemas de resfriamento & 9.677 & 19,4 \\
Mictórios & 3.411 & 6,8 \\
Irrigação de áreas verdes & 144 & 0,3 \\
Limpeza de pisos e pátios & 216 & 0,4 \\
\hline \multicolumn{1}{c}{ Total - usos não potáveis } & $\mathbf{3 8 . 9 1 7}$ & $\mathbf{7 7 , 9}$ \\
\hline Lavatórios & 7.611 & 15,3 \\
Restaurantes & 1.140 & 2,3 \\
Lanchonetes & 1.447 & 2,9 \\
Chuveiros & 693 & 1,4 \\
Outros & 99 & 0,2 \\
\hline \multicolumn{1}{c}{ Total - usos potáveis } & $\mathbf{1 0 9 9 0}$ & $\mathbf{2 2 , 1}$ \\
\hline \multicolumn{2}{c}{ TOTAL } & $\mathbf{4 9 . 9 0 7}$ \\
\hline
\end{tabular}

Observa-se na tabela 22 que o maior consumo de água do AISP é destinado a descargas em bacias sanitárias, representando $51 \%$ do total mensal. Em segundo e terceiro lugares estão os consumos relativos ao sistema de resfriamento e mictórios, $19,4 \%$ e $6,8 \%$, respectivamente.

De acordo com a tabela 22 os usos não potáveis, respondem por $78 \%$ do consumo de água total do aeroporto e, atualmente, são abastecidos com água potável proveniente de fontes subterrâneas. 
A partir do levantamento de dados verificou-se que a demanda atual de água para atender aos usos não potáveis é de, aproximadamente, $38.917 \mathrm{~m}^{3} / \mathrm{mês}$. Porém, cabe ressaltar que esse aeroporto está em processo de ampliação e, de acordo com informações disponibilizadas pela INFRAERO, estima-se que a partir de 2014 a demanda de água será $60 \%$ superior à atual.

\subsection{Características do efluente gerado no AISP}

Com base em dados obtidos através de laudos fornecidos pela INFRAERO e de análises realizadas durante o desenvolvimento da pesquisa foi possível caracterizar o efluente do sistema de esgotamento sanitário do AISP, em relação a alguns contaminantes específicos e de grande relevância quando o objetivo é produzir água de reúso. Na tabela 23 são apresentadas as características do efluente em consideração.

Tabela 25 - Qualidade do efluente tratado

\begin{tabular}{ccc}
\hline Parâmetros & Unidade & Água Bruta \\
\hline Cloretos & $\mathrm{mg} \cdot \mathrm{L}^{-1}$ & 30,5 \\
\hline $\begin{array}{c}\text { Sólidos Dissolvidos } \\
\text { Totais }\end{array}$ & $\mu \mathrm{S} \cdot \mathrm{cm}-1$ & 280 \\
\hline Dureza & $\mathrm{mgCaCO} \cdot \mathrm{L}^{-1}$ & 36 \\
\hline Alcalinidade & $\mathrm{mg} \mathrm{CaCO} \cdot \mathrm{L}^{-1}$ & 26 \\
\hline $\mathrm{pH}$ & & 6,5 \\
\hline $\mathrm{DQO}$ & $\mathrm{mg} \cdot \mathrm{L}^{-1}$ & 61 \\
\hline $\begin{array}{c}\text { Sólidos Suspensos } \\
\text { Totais }\end{array}$ & $\mathrm{mg} \cdot \mathrm{L}^{-1}$ & 49 \\
\hline Turbidez & $\mathrm{UNT}$ & 44 \\
\hline DBO ${ }_{5,20}$ & $\mathrm{mg} \cdot \mathrm{L}^{-1}$ & 15 \\
\hline Compostos Orgânicos & $\mathrm{mg} \cdot \mathrm{L}^{-1}$ & 23,9 \\
\hline Nitrogênio Amoniacal & $\mathrm{mg} \cdot \mathrm{L}^{-1}$ & 8,8 \\
\hline Fosfato & $\mathrm{mg} \cdot \mathrm{L}^{-1}$ & 13,19 \\
\hline Sílica & $\mathrm{mg} \cdot \mathrm{L}^{-1}$ & 16 \\
\hline Alumínio & $\mathrm{mg} \cdot \mathrm{L}^{-1}$ & 0,02 \\
\hline Ferro & $\mathrm{mg} \cdot \mathrm{L}^{-1}$ & 0,014 \\
\hline Manganês & $\mathrm{mg} \cdot \mathrm{L}^{-1}$ & 0,04 \\
\hline Sulfato & $\mathrm{mg} \cdot \mathrm{L}^{-1}$ & 13,21 \\
\hline
\end{tabular}


A bioquímica do tratameto aeróbio e o fato do sistema de lodos ativados operar com elevada concentração de biomassa, conferem a esse processo elevada eficiente na oxidação da matéria orgânica. Nos resultados da tabela 22 são apresentadas as concentrações de substancias orgânicas, relativas ao efluente do processo biológico, expressas por DBO e DQO que são, respectivamente, 15 e $61 \mathrm{mg} \cdot \mathrm{L}^{-1}$. Esses valores são esperados se comparados aos valores dessas variáveis obtidas por outros estudos aplicados a esgoto sanitário. Porém, não foi possível avaliar a eficiência do sistema de tratamento existente no AISP, pois não foram disponibilizados dados relativos à caracterização do esgoto bruto.

A presença de nitrogênio amoniacal não é esperada no efluente de um processo aeróbio que, de acordo com informações disponibilizadas pela INFRAERO, opere com concentrações médias de oxigênio dissolvido de $7 \mathrm{mg}^{-\mathrm{L}^{-1}}$ e idade do lodo superior a vinte dias (Jordão, 2011). Porém, conforme já explicitado não é possível explicar a concentração desse contaminante, pois não foram disponibilizadas, pela INFRAERO, detalhes relativos à caracterização do esgoto bruto e da operação de sistema de tratamento.

$O$ valor relativo à concentração de fosfato no efluente tratado encontra-se acima do máximo citado por MetCalf (2003) para o esgoto bruto que é de $8 \mathrm{mg} \cdot \mathrm{L}^{-1}$. Normalmente, o fosfato presente no esgoto doméstico provem das fezes e de dertergentes utilizados em limpeza de modo gera. No caso do aeroporto, o valor elevado pode ser explicado devido ao fato dos vasos sanitário contribuírem com a maior parte do volume de esgoto gerado, o que pode conferir uma característica disitinta do efluente em questão se comparada a do esgoto sanitário citado em literatura. Porém, como não foi possível obter a caracterização do esgoto bruto gerado no aeroporto e em literatura não foram encontrados dados relativos a esse tipo de efuente, não é possível afirmar se a concentração de fosfato apresentada é proveniente apenas do esgoto gerado no local. 


\subsection{Estabelecimento da pressão de operação}

O gráfico apresentado na figura 29 apresenta o volume de permeado produzido em função da pressão aplicada a montante da membrana.

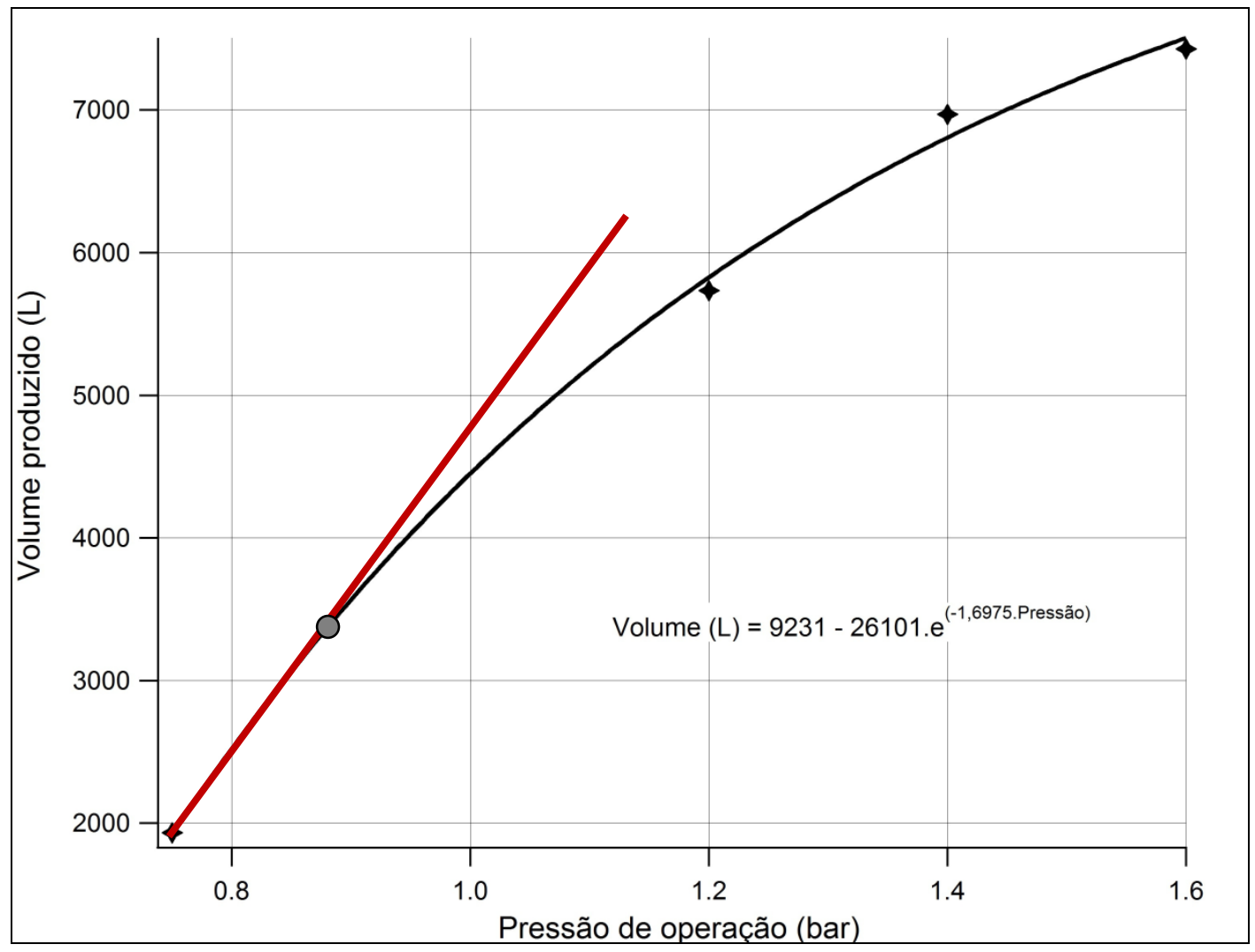

Figura 29- Volume de permeado produzido em função do aumento da pressão

A determinação da pressão ótima de operação foi obtida estabelecendo-se o fluxo crítico, o qual de acordo com a definição apresentada no item 3.3.6 é aquele abaixo do qual a vazão de permeado varia linearmente com a pressão de operação do sistema. No gráfico é possível observar que a partir de uma pressão de, aproximadamente, 0,9 bar a relação entre a variação na produção de permeado em função da pressão de operação deixa de ser linear. Esse fato ocorre devido ao aumento no aporte de contaminantes à superfície da membrana, especificamente sólidos, promovido pelo aumento do fluxo de água através da membrana e da maior compactação destes contaminantes na superfície da membrana, resultante do aumento de pressão. 
Com base nos resultados dos ensaios realizados e em fundamentos teóricos é possível afirmar que, especificamente para o efluente analisado, os fatores relacionados à polarização da concentração passam a interferir na produtividade da membrana quando o sistema é operado com pressões superiores a 1,0 bar.

\subsection{Estabelecimento da frequência de retrolavagem}

A frequência ideal de retrolavagem foi estabelecida analisando-se o volume de permeado produzido em 120 horas de operação do sistema, empregando-se 3 frequências distintas de retrolavagem - 30, 45 e 60 minutos, conforme ilustra a figura 30.

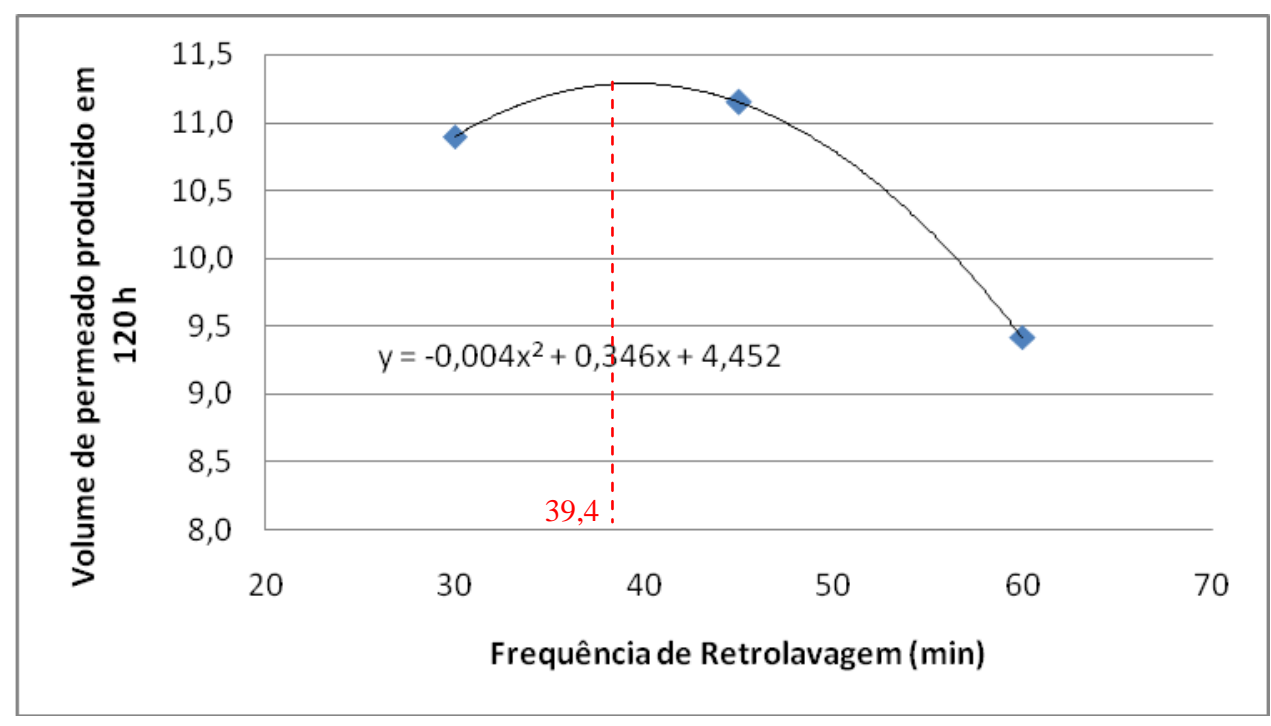

Figura 30- Volume de permeado produzido em função da frequência de retrolavagem

Com base nos dados apresentados na figura 30, verifica-se que a máxima eficiência de produção de água ocorre quando a frequência de contralavegem é de 39,4 minutos. Esse tempo foi determinado derivando-se a equação polinomial apresentada no gráfico da figura 31 e igualando-se a expressão resultante a zero. Através da derivada foi obtido o ponto de máximo da curva, o qual representa no eixo das ordenadas, o volume máximo de permeado produzido no período considerado e, no eixo das abscissas o respectivo tempo de retrolavagem $-39,4 \mathrm{~min}$. 
Com base nos resultados apresentados e em dados de literatura é possível afirmar que quando a retrolavagem é realizada em intervalos superiores a 39,4 min. ocorre uma redução na produção de permeado, o que pode ser explicado pela intensificação na interferência de fatores associados à polarização da concentração.

\subsection{Eficiência do sistema em relação à produção de água tratada}

Com base no tempo para realização de contralavagens e na pressão de operação estabelecidos foi possível obter a vazão média de permeado produzida pelo sistema 160 L. $\mathrm{h}^{-1}$. Com base nessa informação e no volume de permeado gasto com retrolavagem obteve-se a taxa de recuperação do sistema que é de $70 \%$.

\subsection{Estabelecimento da frequência de limpeza química}

Para o estabelecimento da frequência de limpeza química a unidade piloto operou por aproximadamente $300 \mathrm{~h}$, sendo monitoradas a cada dois minutos a vazão de permeado e a pressão na entrada da membrana. Com esses dados foi possível avaliar as variações relativas à vazão de permeado e à pressão na entrada da membrana ao longo do tempo de operação, conforme ilustram as figuras 31 e 32 respectivamente.

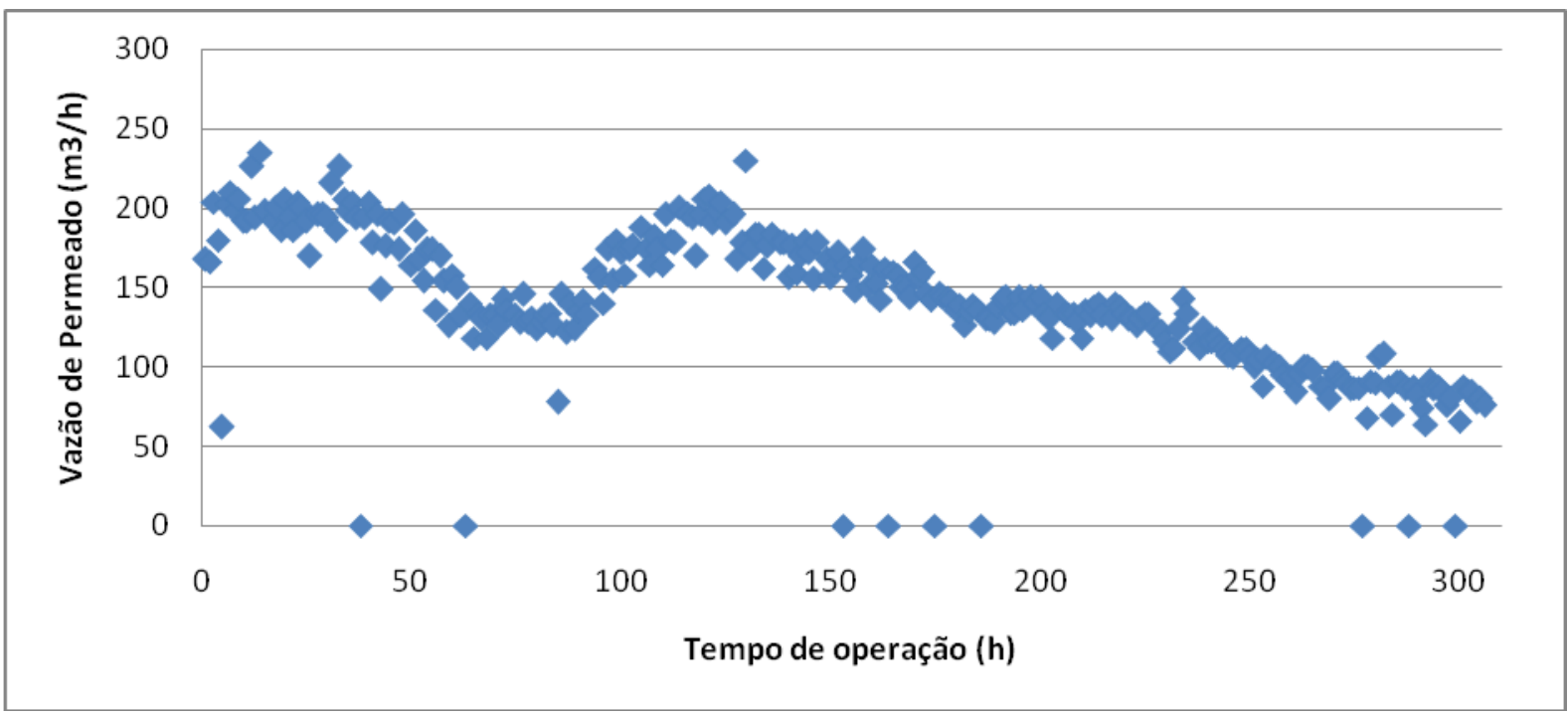

Figura 31- Variação da vazão de permeado em função do tempo de operação 


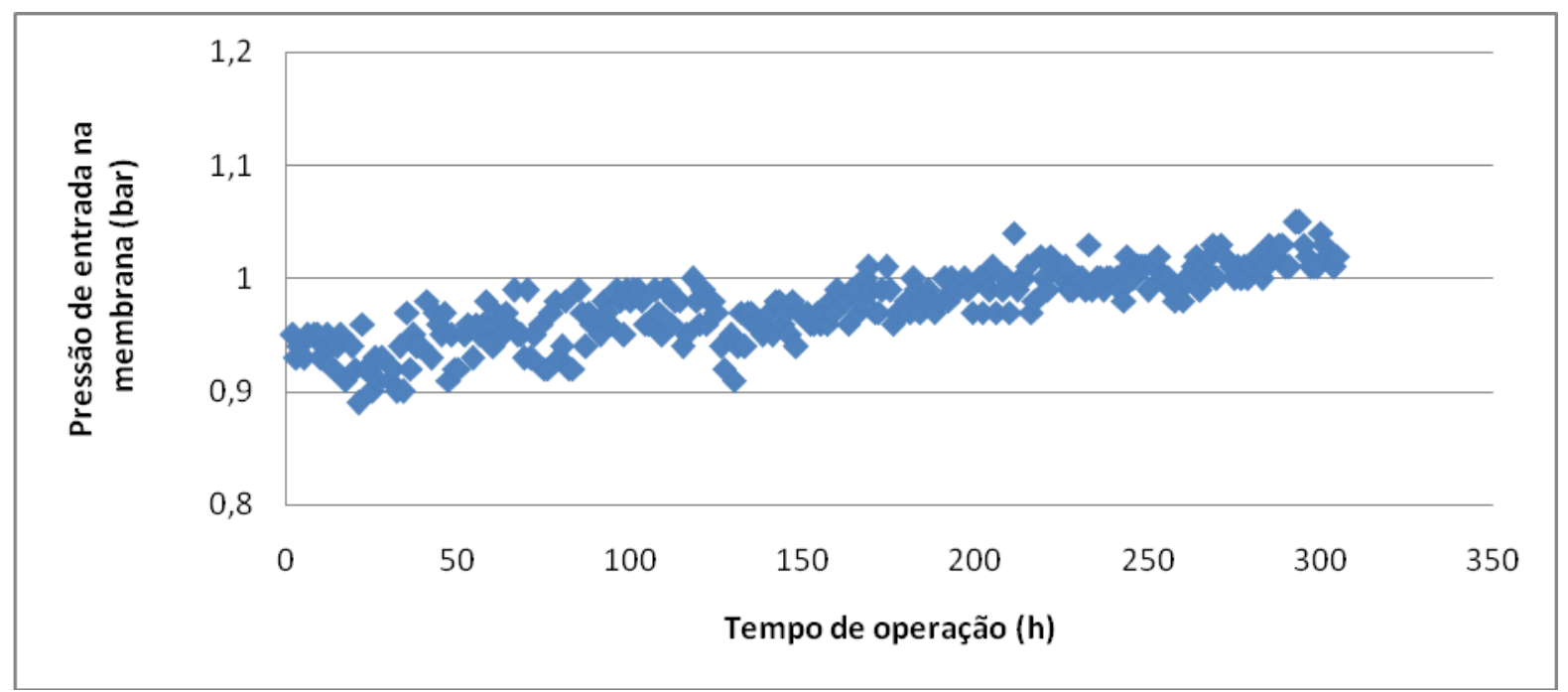

Figura 32- Variação da pressão na entrada da membrana em função do tempo de operação

Na figura 31 observa-se que entre 50 e 100 horas de operação houve uma queda significativa no fluxo de permeado. Esse fato pode ser explicado por um problema de ordem hidráulica no sistema, uma vez que, além do fluxo retomar após o período citado, não foram observadas variações significativas na pressão de alimentação (Figura 32) e na qualidade da água bruta no período.

Com base na avaliação dos gráficos apresentados nas figuras 31 e 32 é possível verificar que a partir de 1 bar de pressão ocorre uma queda acentuada e contínua no fluxo de permeado. Esses resultados demostram que a partir de 1 bar o sistema passa a operar em uma condição desfavorável, tendo em vista que a variação do fluxo não segue uma correlação linear com a pressão. Isso pode ser explicado pelo fato de que, nessa condição, a compactação da camada gel e a formação de torta passam a ser relevantes, fato que foi observado durante os ensaios para estabelecimento da pressão ideal de operação. Se for considerado o tempo de operação pode-se afirmar que a formação do biofilme é outro fator que passa a interferir na formação do biofilme. Portanto, para o caso específico do efluente em questão, pode-se definir que um aumento de $10 \%$ na pressão de operação, estabelecida inicialmente, é um indicativo da necessidade de interrupção na operação do sistema para realização de limpeza química. 


\subsection{Eficiência do sistema em relação à remoção de contaminantes}

Os resultados relativos à eficiência da unidade piloto de ultrafiltração em relação à remoção de contaminantes e os resultados das análises de água bruta e permeado obtidos durante o desenvolvimento da pesquisa estão apresentados no gráfico da figura 33 e na tabela 24.

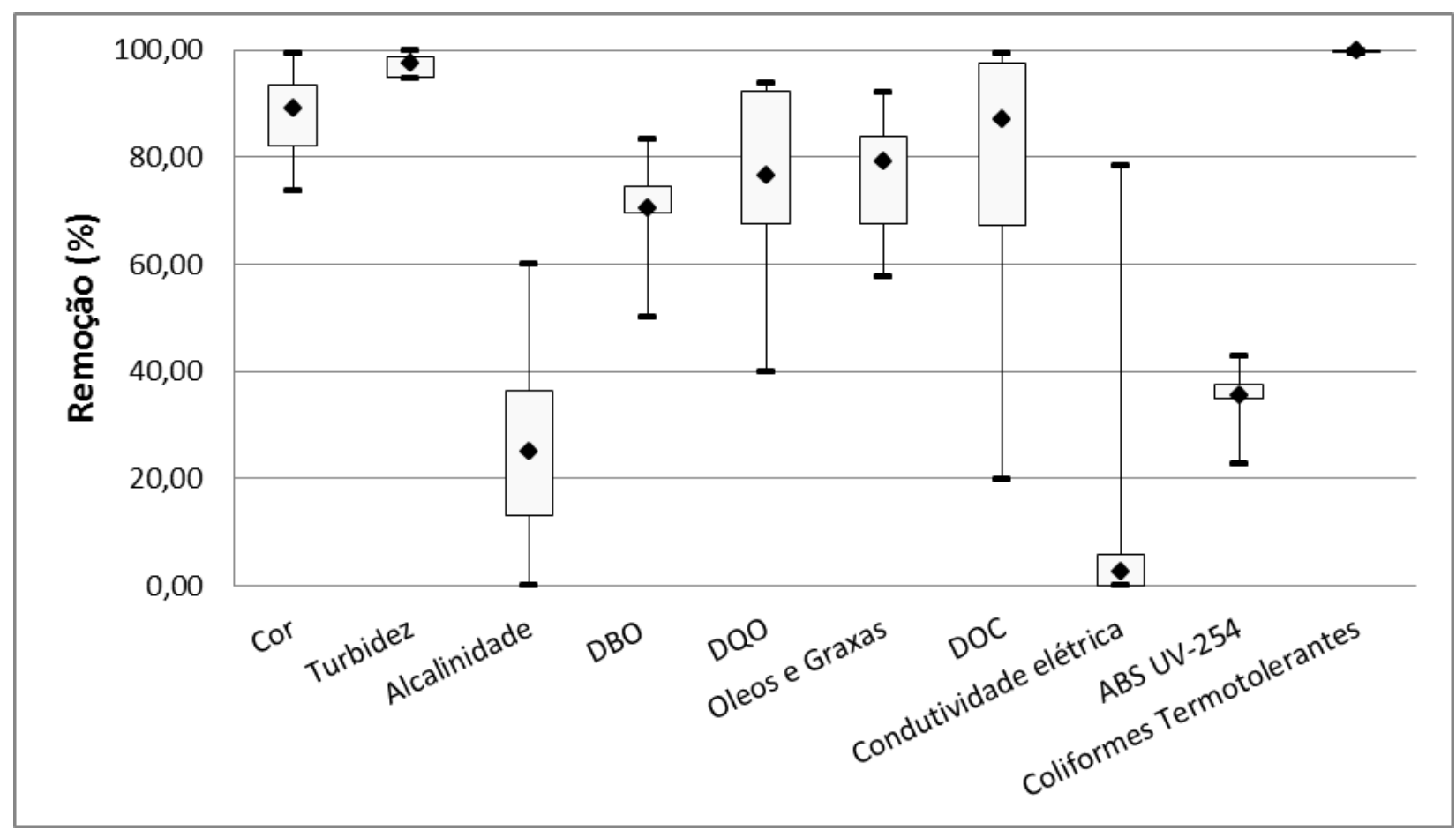

Figura 33- Eficiência do sistema em relação à remoção de contaminantes 
Tabela 26 - Valores médio, mínimo e máximo dos resultados relativos às análises de água bruta e permeado

\begin{tabular}{|c|c|c|c|c|c|c|c|}
\hline VARIÁVEIS & Unidade & Amostra & Mínimo & Média & Máximo & $\begin{array}{l}\text { Desvio } \\
\text { Padrão }\end{array}$ & $\begin{array}{l}\text { Eficiência do } \\
\text { Sistema (\%) }\end{array}$ \\
\hline Cor & (PtCo) & Bruta & 122 & 262 & 402 & 89,1 & \\
\hline \multirow{2}{*}{$\mathrm{pH}$} & & Bruta & 6,1 & 6,6 & 7,3 & 0,4 & \\
\hline & & Permeado & 6 & 6,5 & 7,07 & 0,3 & \\
\hline Turbidez & (NTU) & Bruta & 9,2 & 44 & 119 & 37,7 & \\
\hline \multirow{2}{*}{ Condutividade Elétrica } & \multirow{2}{*}{$(\mu \mathrm{S} / \mathrm{cm})$} & Bruta & 190 & 518 & 812 & 173,8 & \\
\hline & & Permeado & 41 & 498 & 798 & 214,9 & 3,9 \\
\hline \multirow{2}{*}{ Alcalinidade } & \multirow{2}{*}{$(\mathrm{mg} \mathrm{CaCO} / \mathrm{L})$} & Bruta & 9 & 14 & 26 & 4,4 & \\
\hline & & Permeado & 4 & 11 & 18 & 3,6 & 21,4 \\
\hline Carbono Orgânico Dissolvido & $(\mathrm{mg} / \mathrm{L})$ & Bruta & 7,1 & 23,9 & 54 & 13,6 & \\
\hline DBO (mg/l) & $(\mathrm{mg} / \mathrm{L})$ & Permeado & $<5$ & $<5$ & $<5$ & 0 & 66,7 \\
\hline \multirow{2}{*}{ DQO (mg/l) } & \multirow{2}{*}{$(\mathrm{mg} / \mathrm{L})$} & Bruta & 11 & 61 & 100 & 29,7 & \\
\hline & & Permeado & 5 & 2 & 29 & 7,6 & 96,7 \\
\hline \multirow{2}{*}{ Coliformes termotolerantes } & \multirow{2}{*}{ (NMP/100 mL) } & Bruta & 68 & 46034 & 92000 & 24688 & \\
\hline & & Permeado & 0 & 3 & 40 & 11 & 100 \\
\hline \multirow{2}{*}{ Absorbância em UV 254} & \multirow{2}{*}{ Abs } & Bruta & 0,167 & 0,200 & 0,226 & 0,02 & \\
\hline & & Permeado & 0,129 & 0,129 & 0,129 & 0 & 35,5 \\
\hline
\end{tabular}


A média de remoção de cor obtida pelo sistema permaneceu em torno de $90 \%$ em praticamente todas as análises. Tendo em vista esse fato e que a membrana de ultrafiltação não remove substâncias com baixa massa molecular, é possível afirmar que grande parte dos compostos que conferem cor à água bruta encontram-se na forma coloidal, os quais podem ser provenientes do próprio esgoto e também da decomposição de substâncias naturais, tendo em vista as características de uso e ocupação do solo no entorno da lagoa. Cabe ressalta que, apesar da remoção apresentada ainda há cor remanescente que, provavelmente é conferida pela presença de substâncias de baixo peso molecular.

Como pode ser observado no gráfico da figura 33 o sistema elevada eficiência com relação à remoção de turbidez. Das análises de permeado realizadas apenas uma apresentou um valor elevado de turbidez - 14,2 UNT, conforme tabela 24 . Um aumento súbito de turbidez pode ser causado pelo rompimento da membrana, porém analisando-se os resultados das amostras subsequêntes é possível afirmar que não houve dano à membrana. Sendo assim, atribui-se a discrepância do valor a uma possível contaminação da amostra.

O valor médio de turbidez apresentado na tabela 24 foi calculado considerando-se o valor de 14,2 UNT. Tendo em vista que a faixa de variação aceitável para a turbidez da amostra é 0,2 a 7,4 UNT, calculada através da média mais ou menos uma vez e meia o desvio padrão, é possível afirmar que o valor de 14,7 UNT é um outlier. Assim sendo, a média para valores de turbidez é de 1 UNT e a eficiência da membrana em relação aos contaminantes que conferem essa característica à água é de $97 \%$ valor próximos dos obtidos em outras pesquisas (LIU et. al. 2007, GANDINI et. al. 1996, RAVAZZINI et. al. 2005)

Relativamente à variação significativa da turbidez na água bruta deve-se atribuí-la à observação de aportes de sólidos suspensos após um episódio de chuva intensa ou à proliferação de algas em dias quentes e ensolarados, ambas as observações verificadas visualmente na lagoa.

Cabe ressaltar que, apesar da elevada turbidez em praticamente todas as amostras de água bruta, a qualidade do permeado em relação a essa variável apresentou-se praticamente constante e igual a 1 UNT. 
A alcalinidade é um parâmetro muito importante no presente estudo, tendo em vista que se avalia a viabilidade de utilizar a água produzida pelo sistema de membranas no abastecimento da torre de resfriamento. Porém, os resultados da pesquisa mostraram que, no que se refere à alcalinidade, o efluente secundário já atende ao padrão estabelecido por Crook, 1996 apud Mierzwa Hespanhol, 2005 (tabea 6, página 29), que é de $350 \mathrm{mg} \mathrm{CaCO}_{3} \mathrm{~L}^{-1}$, valor considerávelmente superior se comparado àquele obtido nas análises do efluente secundário (26 mg $\left.\mathrm{CaCO}_{3} \mathrm{~L}^{-1}\right)$. Contudo, apesar da membrana de utrafiltração não ter como objetivo a remoção de alcalinidade devido ao fato desses contaminates estarem na forma iônica, o sistema apresentou uma remoção média de $30 \%$ em relação a essa variável. Isso pode ser explicado devido ao fato desse tipo de contaminante estare associado à substâncias que apresentam elevada massa molecular e que devido a essa característica são retidas pela membrana.

Com relação às variáveis de qualidade DBO e Coliformes Termotolerantes, parâmetros estabelecidos pela EPA, o sistema apresentou resultados satisfatórios, sendo os percentuais de remoção em torno de 86 e $100 \%$, respectivamente, que são próximos aos obtidos em outros estudos (Arévalo et. al. 2009, Gandini et. al. 1996).

Na 24 é possível observar que uma das amostras apresentou uma contagem de Coliformes Termotolerantes igual a $40 \mathrm{NMP} / 100 \mathrm{~mL}^{-1}$. Tendo em vista que 0 diâmetro de poro da membrana de ultrafiltração não permite a passagens desse tipo de organismo, conforme ilustra a figura 9 , página 45 , sua presença no permeado pode se dar devido a dois fatores. O primeiro seria uma ruptura na membrana, mas isso viria acompanhado de um aumento na turbidez, fato que não foi observado. A outra possibilidade, e a mais provável, seria uma contaminação da amostra, o que é mais aceitável tendo em vista que os resultados das análises de turbidez não sofreram alteração e não foram detectados coliformes termotolerantes nas amostras subsequentes. Tendo em vista as possíveis justificativas para a contagem de $40 \mathrm{NMP} / 100 \mathrm{~mL}^{-1}$, associado a uma das amostras, é possível afirmar que a eficiência da membrana em relação à remoção de Coliformes Termotolerantes foi de $100 \%$. Esse fato que permite a redução na 
dosagem de cloro para desinfecção final da água de reúso, sendo necessário manter apenas o residual para garantir a qualidade sanitária da água de reúso ao longo do sistema de distribuição;

A condutividade elétrica é um parâmetro que mede indiretamente a quantidade de sólidos dissolvidos na água. Através da análise do gráfico apresentado na figura 33 é possível comprovar a ineficiência da membrana de ultrafiltração em relação à remoção desse tipo de contaminante. A tabela 24 reforça essa afirmação, pois os valores de condutividade elétrica apresentados pela água bruta são muito próximos dos valores associados às amostras de permeado conforme relatado em outros estudos (RAZINZI et. al 2005; MIERZWA, 2008).

Devido à presença de uma rodovia, com tráfego intenso, próxima à lagoa e de um grande número de oficinas no AISP, destinadas à manutenção de aeronaves, e tendo em vista a possibilidade dos efluentes gerados nessas unidades serem despejados de forma irregular diretamente na rede de esgoto, julgou-se necessário o monitoramento das concentrações de óleos e graxas no efluente do sistema de esgotamento sanitário. A tabela 24 apresenta concentração média de óleos e graxas na água bruta de, aproximadamente, $24 \mathrm{mg} \cdot \mathrm{L}^{-1}$, valor relativamente baixo quando comparado ao estabelecido por Metcalf \& Eddy (1991) para esgoto

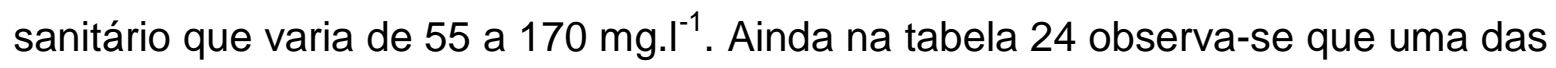
amostras apresentou uma concentração de óleos e graxas de $62 \mathrm{mg}^{-1}{ }^{-1}$ Esse resultado é relativamente alto quando comparado aos das outras amostras e pode ser explicado pela ocorrência de uma contribuição indevida das oficinas mecânicas ou pela contaminação da água da lagoa por drenagem de água pluvial proveniente da rodovia. Mesmo a água bruta apresentando variação na concentração de óleos e graxas, todas as amostras do permeado apresentaram concentrações desse contaminante inferiores a $5 \mathrm{mg} \cdot \mathrm{L}^{-1}$, conforme 24 , sendo a remoção média em torno de $70 \%$.

Os resultados do estudo demonstram que ocorreu uma variação significativa nas concentrações de DQO nas amostras de água bruta. Esse fato pode ser explicado por algum problema operacional que tenha interferido na eficiência da estação de tratamento de esgoto ou por episódios de precipitação intensa que promoveram à 
lagoa o aporte de contaminantes presentes no solo correspondente à drenagem das áreas circundantes.

A variável Absorbância de Radiação UV em $254 \mathrm{~nm}$ é um indicativo da presença de matéria orgânica natural. O sistema apresentou remoção média de, aproximadamente, 35\% para esta variável de qualidade. Esse valor é próximo daqueles obtidos em outras pesquisas (WANG et. al. 2012; SONH et. al., 2011; KONIECZNY, SAKOL e BODZEK, 2006; GADANI et. al. 1996)

Com base nos resultados apresentados na tabela 24, em comparação aos dados apresentados nas tabelas 25 e 26, é possível afirmar que o efluente produzido pelo sistema de membrana, utilizado no presente estudo, é adequado para atender diversas demandas relativas aos usos não potáveis identificados, cabendo comentários específicos, em relação à determinadas variáveis de qualidade, os quais são apresentados na sequência.

Tabela 275 - Comparação entre a qualidade da água produzida pelo sistema de ultrafiltração e aquela exigida pelos usos urbanos

\begin{tabular}{ccc}
\hline Variáveis & $\begin{array}{c}\text { Qualidade do } \\
\text { Permeado }\end{array}$ & $\begin{array}{c}\text { Padrão de Qualidade } \\
\text { estabelecido pela EPA (2004) }\end{array}$ \\
\hline $\mathrm{pH}$ & 6,4 & 6 a 9 \\
$\mathrm{DBO}_{5,20}\left(\mathrm{mg}_{\mathrm{L}} \mathrm{L}^{-1}\right)$ & 2 & $<10$ \\
Turbidez (NTU) & 1 & $<2$ \\
Coliformes Termotolerantes & Ausentes & Ausentes $/ 100 \mathrm{~mL}$ \\
\hline
\end{tabular}

A tabela 25 mostra que houve variação pouca significativa nos valores de $\mathrm{pH}$, e praticamente todas as amostras apresentaram valores muito próximos aos valores estabelecidos pela EPA (2004) para água de reúso

Já com relação à utilização da água produzida pela unidade piloto de ultrafiltração para atender a demanda do sistema de resfriamento, cabem algumas ressalvas. A tabela 26 mostra que, praticamente, todas as variáveis atenderam ao padrão imposto para a atividade em questão. Porém, no que se refere a nitrogênio amoniacal, fosfato e compostos orgânicos, o efluente do sistema de membrana apresenta concentrações acima do limite estabelecido. 
Tabela 28 - Comparação entre a qualidade da água produzida pelo sistema de ultrafiltração e aquela exigida para reposição em sistemas de resfriamento

\begin{tabular}{|c|c|c|}
\hline Parâmetros & Permeado & $\begin{array}{l}\text { Valores } \\
\text { Limites }\end{array}$ \\
\hline Cloretos & 27 & 500 \\
\hline Sólidos Dissolvidos Totais & 349 & 500 \\
\hline Dureza & 32 & 650 \\
\hline Alcalinidade & 11 & 350 \\
\hline $\mathrm{pH}$ & 6,5 & 6,9 a 9,0 \\
\hline DQO & 61 & 75 \\
\hline Sólidos Suspensos Totais & $<10$ & 100 \\
\hline Turbidez & 1,5 & 50 \\
\hline DBO & 15 & 25 \\
\hline Compostos Orgânicos $^{++}$ & 3,8 & 1 \\
\hline Nitrogênio Amoniacal & 7,9 & 1 \\
\hline Fosfato & 13 & 4 \\
\hline Sílica & 12 & 50 \\
\hline Alumínio & 0,01 & 0,1 \\
\hline Ferro & 0,04 & 0,5 \\
\hline Manganês & 0,06 & 0,5 \\
\hline Sulfato & 13 & 200 \\
\hline
\end{tabular}

Com base nos resultados apresentados na tabela 26 verifica-se que a água produzida pelo sistema de ultrafiltração atende a, praticamente, todos os parâmetros estabelecidos para água destinada à sistemas de resfriamento, com exceção de das variáveis Compostos orgânicos, Nitrogênio Amoniacal e Fosfato. Ressalta-se que para utilizar a água produzida pelo sistema de ultrafiltração no abastecimento das torres de resfriamento, cabe uma avalição mais detalhada em relação à operação do sistema de tratamento biológico e das características do 
esgoto bruto, para identificar a quais fatores estão associados a presença dos contaminantes citados no efluente da estação de tratamento. Não foi possível realizar essa discussão no presente estudo devido à falta de dados.

\section{6 - CONCLUSÕES E CONSIDERAÇÕES FINAIS}

O desenvolvimento de pesquisas relacionadas ao processo de separação por membranas é de grande relevância para aplicação dessa tecnologia de forma adequada, principalmente, para o reúso de água - prática que propicia a conservação dos recursos hídricos, os quai, em algumas regiões do país, são bastante limitados.

Com a realização do estudo foi possível obter uma melhor compreensão sobre o uso do processo de ultrafiltração para a obtenção da água de reúso a partir de efluentes secundários, especificamente em relação aos parâmetros operacionais e ao desempenho do sistema em relação à produção de água, bem como sobre a eficiência em relação à remoção de contaminantes específicos, considerando a utilização de uma membrana de ultrafiltração modelo Romicon HF 66-45-XM50P da marca Koch:

Durante o desenvolvimento da pesquisa foram obtidas algumas conclusões relativas ao desempenho operacional do sistema e à eficiência do mesmo na remoção de contaminantes específicos:

$\checkmark$ Os resultados obtidos através dos ensaios desenvolvidos mostraram que, a condição ideal para do sistema de ultrafiltração, especificamente para o efluente avaliado, é operálo com pressão de 0,9 bar e realização de contralavagem a cada 39,4 min. Para valores superiores, tanto de pressão como de frequência de contralavagem, o sistema passa a operar em uma condição desfavorável, pois os fatores associados à polarização da concentração passam a interferir de forma significativa na passagem do fluxo pela membrana. 
$\checkmark$ O terceiro e ultimo teste realizado demostrou que a partir de $200 \mathrm{~h}$ de operação ocorre uma queda acentuada na vazão de permeados, fato que determina a necessidade de parada para reaização de limpeza química. Nesse caso, somado aos fatores associados à concetração da polarização, ocorre a formação do biofilme que contribui de forma significativa com a redução na produtividade

$\checkmark$ Em termos de produtividade o sistema apresentou os seguintes resultados:

- Vazão média de permeado $=160$ L. $\mathrm{h}^{-1}$

- Taxa de recuperação da membrana $=70 \%$

- Taxa de produção da membrana $=26,23 \mathrm{~L} \cdot \mathrm{h}^{-1} \mathrm{~m}^{-2}$

Os resultados das análises qualitativas do permeado indicam um potencial de reúso para descarga em bacias sanitárias, irrigação de áreas verdes, lavagem de pisos, pistas e pátios e reserva para combate a incêndios, tendo em vista, principalmente, a qualidade sanitária da água produzido pelo sistema de ultrafiltração. Já com relação à utilização dessa água, para atender à demanda relativa às torres de resfriamento, cabe uma avaliação mais detalhada em relação às variáveis Nitrogênio Amoniaca, Fosfato e Matéria orgânica. A presença desses contaminantes pode estar relacionada ao funcionamento inadequado da estação de tratamento 


\section{7 - RECOMENDAÇÕES}

De acordo com orientação do fornecedor o tipo de membrana avaliada no estudo permite a realização de retrolavagens com soluções alcalinas para redução do potencial de depósito sobre a membrana e da frequência de paradas para limpeza química. A cada três retrolavagens com o permeado é feita uma com alcalinizante. Esse procedimento possibilita remover substâncias orgânicas adsorvidas na membrana e, no caso da realização da retrolavagem com adição de cloro no permeado, também reduzir o potencial de formação de biofilme. Esse procedimento não foi avaliado, porém recomenda-se um estudo mais específico relacionado a ele, o que poderá resultar em um melhor desempenho do sistema de ultrafiltração.

Tendo em vista a presença de Matéria Orgânica, Nitrogênio Amoniacla e Fosfato, em concentrações relativamente elevadas, no efluente do sistema de tratamento de esgoto do AISP, recomenda-se a realização de um estudo aprofundado capaz de identificar a proveniência desses contaminantes e se exitem falhas associadas ao projeto ou à operação da estação. Essa análise não foi realizada no presente estudo devido à falta de dados. Identificando as possíveis falhas no sistema o reúso para torre de resfriamento pode ser aplicado com segurança. 


\section{8- REFERÊNCIAS BIBLIOGRÁFICAS}

ANADÃO, P. Ciência e Tecnologia de Membranas. Artliber. São Paulo, 2010.

ASANO, T. Wastewater Raclamation and Reuse. Water Quality Management Library Vol. 10. Technomic Publishing, Lancaser, Pensilvania, USA, 1998.

ASANO, T.; BURTON, F. L.; LEVERENZE, H. L.; TSUCHIHASHI, R.; TCHOBANOGLOUS, G. Water Reuse - Issues, Technologies and Applications Metcalf \& Eddy AECON McGraw Hill - USA, 2007.

ANTONY G. Fane. Sustainability and membrane processing of wastewater for reuse. Desalination 202 (2007) 53-58

ARÉVAlO, J.; GARRALÓNB, G.; PLAZAB, F.; MORENOA, B.; PÉREZA, J.; GÓMEZ, M. A.; Wastewater reuse after treatment by tertiary ultrafiltration and a membrane bioreactor (MBR): a comparative study. Desalination 243 (2009) 32-41

BAHRI, A. Water reuse in Middle Eastern and North African countries. Chapter 2. In: JIMENEZ, B. and ASANO, T. Water Reuse - An International Survey of current practice, issues and needs. IWA Publishing. Londom,UK. 2008.

BEZERRA, L. F. Avaliação da remoção de matéria orgânica carbonácea e nitrogenada de águas residuárias utilizando biorreatores de membranas, 2010. Dissertação de Mestrado apresentada à Faculdade de Engenharia UNESP, Ilha Solteira - SP.

CEBALUS,B. S. O. Eliminación de microorganismos por médio del tratamiento de lãs águas residuales. Capítulo 4. In: MENDONÇA, S. R. Sistemas de Lagunas de Estabilización $1^{a}$ Edição. McGraw-Hill Interamericana, Santa Fé de Bogotá Colombia. 2000.

CHERYAN, M. Ultrafiltration and Microfiltration: Handbook. CRC PRESS, $2^{\mathrm{a}} \mathrm{ed}$. 1998.

CHOI, J. G., BAE, T. H., KIM, J. H. et al., 2002, "The Behavior of Membrane Fouling Initiation on The Crossflow Membrane Bioreactor System", Journal of Membrane Science, v. 203, pp.103-113. 
COSTANZI, R. N. Tratamento de efluentes domésticos por sistemas integrados de lodos ativados e membrana de ultrafiltração visando o reúso de água. 2007. Tese de Doutorado apresentada à Escola Politécnica da Universidade de São Paulo. São Paulo - SP

CÔTE, P.; MASINI, M.; MOURATO, D. Comparison of membrane options for water reuse and reclamation. Desalination. vol. 167 p.1 - 11, Canada, 2004.

Departamento de Águas e Energia Elétrica do Estado de São Paulo (DAEE). Pesquisa de dados dos recursos hídricos do estado de São Paulo. Disponível em http://www.aplicacoes.daee.sp.gov.br/usosrec/fchweb.html, Acesso em: 27/08/2012.

DAVIS, R. H. Definitions Chapter 31 in Membrane Handbook. Chapman \& Hall. New York, 1992

EPA Guidelines for Water Reuse - Environmental Protection Agency - 2004, disponível em:

http://www.epa.gov/nrmrl/wswrd/dw/smallsystems/pubs/625r04108.pdf Acesso em $16 / 10 / 2012$

EPA Membrane Filtration Guidance Manual. United States Environmental Protection Agency. 2003

FIRJAN Manual de Conservação e Reúso de Água na Indústria. Rio de Janeiro 2006

FUNAMIZU, N.; ONITSUKA,T.; HATORI, S. Water Reuse in Japan Chapter 20. In: JIMENEZ, B. and ASANO, T. Water Reuse - An International Survey of current practice, issues and needs. IWA Publishing. Londom,UK. 2008.

Fundo de População das Nações Unidas (UNFPA) - 2010, disponível em http://www.unfpa.org.br/novo Acesso 15/08/2012

GÓMEZ, M.; PLAZA, F.; GARRALÓN, G.; PÉREZ, J.; GÓMEZ, M. A. A comparative study of tertiary wastewater treatment by physicochemical-UV process and macrofiltration-ultrafiltration technologies. Desalination. Vol. 202, p. 369-376. 2007 
HAMADA, Toyozo.; MIYAZAKI, Yasumitsu. Reuse of carwash water with a cellulose acetate ultrafiltration membrane aided by flocculation and activated carbon treatments. Desalination. v.169, 2004.

HESPANHOL, I. Who guidelines and national Standards for reuse and water quality. Water Research, vol. 28, nº 1 p. 119-124. 1994

HESPANHOL, I. Água na Agricultura e Pecuária. Capítulo 09 in: REBOUÇAS, A. C.; BRAGA, B. e TUNDISI, J. G. Águas Doces no Brasil: Capital ecológico, uso e conservação. $3^{a}$ Edição. São Paulo, Escrituras editora, 2002.

HESPANHOL, I.; Um novo paradigma para a gestão dos recursos hídricos. Estudos Avançados. vol.22, n 63, São Paulo. 2008.

HOWELL, J.A. Future of membranes and membrane reactors in green technologies and for water reuse. Desalination, vol. 162 p.1 - 11, United Kingdom, 2004.

Instituto Brasileiro de Geografia e Estatística (IBGE), Pessoas residentes, regiões e as unidades da federação - 2010, disponível em http://www.ibge.gov.br/home/estatistica/populacao/censo2000/tabelabrasil111.sht m Acesso em: 15/08/20112

JUDD, S. The MBR book - Principles and Applications of Membrane Bioreactors in Water and Wastewater Treatment. First edition. Elsevier , 2006.

KULKARNI, S.S.; LI, N.N.; E. W. Introduction and Definitions. In Handbook Membranes. Chapman \& Hall. 1992.

KOCHKLEEN $^{\circledR}$ Membrane Cleaners Work Across the Board. Disponível em http://www.kochmembrane.com/prod_kochkleen.html .

Acesso em 25/08/2010. 
KONIECZNY, K.; SAKO, D.; BODZEK M. Efficiency of the hybrid coagulation-ultrafiltration water treatment process with the use of immersed hollow-fiber membranes. Desalination, vol. 198 p. 102-110 Polônia, 2006.

KWON, D. Y.; VIGNESWARAN, S.; FANE, A.G., BEM AIM, R. Experimental determination of critical flux in cross-flow microfiltration. ELSEVIER, Separation and Purification Technology, p. $169-181,2000$.

LIU, Z.; QUN, M.; AN, W.; SUN, Z. An application of membrane bio-reactor process for the wastewater treatment of Qingdao International Airport. Desalination, vol. 202 p.144 - 149, China, 2007.

MALLEVIALLE, J.; ODENDAAL, P.E. e WIESNER, M.R. The emergence of membrane in water and wastewater treatment. Capítulo 1. In: Water treatement membrane processes. AWWA, 1996.

MANCUSO, P.C.S. Sistemas de reuso de água: projetos e estudos de casos. Capítulo 14 in: MANCUSO, P.C.S.; SANTOS, H. F. (Editores). Reúso de Água. Editora Manole. 2003.

MENDONÇA, S. R. Sistemas de Lagunas de Estabilización $1^{\text {a }}$ Edição. McGrawHill Interamericana, Santa Fé de Bogotá - Colombia. 2000.

METCALF, L. \& EDDY, H. Wastwater Engineering: Treatment, Disposal and Reuse. $3^{\text {a }}$ edição, McGraw-Hill. New York, USA. 1991.

MIERZWA, J. C. (2002). O Uso Racional e o Reúso como Ferramentas para o Gerenciamento de Águas e Efluentes - Estudo de Caso da Kodak Brasileira. Tese de Doutorado apresentada a Escola Politécnica da Universidade de São Paulo.

MIERZWA, J.C. Desafios para o tratamento de água de abastecimento e o potencial de aplicação do processo de ultrafiltração. 2009. Tese de livre docência apresentada à Escola Politécnica da Universidade de São Paulo. São Paulo - SP.

MIERZWA, J.C. e HESPANHOL, I. Água na indústria - Uso racional e reúso. Oficina de Textos. São Paulo, 2005. 
MIERZWA, J.C.Processos de Separação por Membranas para Tratamento de Água. Capítulo 8. In CONTRIBUIÇÃO AO ESTUDO DA REMOÇÃO DE CIANOBACTÉRIAS E MICROCONTAMINANTES ORGÂNICOS POR MEIO DE TÉCNICAS DE TRATAMENTO DE ÁGUA PARA CONSUMO HUMANO PROSAB 4. 2006

MIERZWA, J.C.; SILVA, M. C. C.; RODRIGUES, L. B. e HESPANHOL, I. Tratamento de água para abastecimento público por ultrafiltração: Avaliação comparativa através dos custos diretos de implantação e operação com os sistemas convencional e convencional com carvão ativado. Engenharia Sanitária e Ambiental, v. 13, n. 1, p. 78-87, Jam/mar, 2008.

MULDER, M. Basic Principles of Membranes technology $2^{\text {a }}$ edição - Kluwer Academic Publishers. Dordrecht, 1996.

NAZZAL, Y. K.; MANSOUR, M.; NAJJAR, M.; MCCORNICK, P. Wastewater Reuse Law and Standards in the Kingdom of Jordan. The Ministry of Water and Irrigation. 2000.

OKPALA, W. O. Prospecção de tecnologia para a implantação da prática de reúso de água no aeroporto internacional de São Paulo em Guarulhos. 2005 Dissertação de mestrado apresentada à Escola Politécnica da Universidade de São Paulo. São Paulo - SP

PHILIPPI, A. J. Reúso de água: uma tendência que se firma. in: MANCUSO, P.C.S.; SANTOS, H. F. (Editores). Reúso de Água. Editora Manole. 2003.

PROJETO AQUAPOLO - ano 1 - no 1, setembro 2011 disponível em http://www.aquapolo.com.br/wp-content/uploads/2012/02/01revista .pdf Acesso $15 / 10 / 2012$

RAVAZZINI, A.M.; NIEUWENHUJZEN,A.F.;GRAAF,J.H.M.J. Direct ultrafiltration of municipal wastewater comparison between filtration of raw sewage and primary clarifier effluent. Desalination, vol. 178 p.51 - 62, Netherlands, 2005.

RIDGWAY, H. F.; Membrane Biofouling. Chapter 6. In: AWWA Resarch Foundation, Lyonnaise de Eaux, South Africa Wather Research Commission. Treatment Membrane Processes. McGraw- Hill. 1996. 
SANTOS, H. F. e MANCUSO, P.C.S. A escassez e o reúso água em âmbito mundial uma tendência que se firma. Capítulo 1 in: MANCUSO, P.C.S.; SANTOS, H. F. (Editores). Reúso de Água. Editora Manole. 2003.

SCHNEIDER, R. P, TSUTIYA, M. T. Membranas Filtrantes para o Tratamento de água, esgoto e água de reúso. $1^{\circ}$ edição. ABES - Associação Brasileira de Engenharia Sanitária e Ambiental. São Paulo, 2001.

SONG, H.; SHAO, J.; HE, Y.; HOU, J.; CHAO, W. Natural organic matter removal and flux decline with charged ultrafiltration and nanofiltration membrane. Journal of Membrane Science, vol. 376, p. 179 - 187. China, 2011

SILVA, M. C. C. Clarificação do concentrado gerado no tratamento de água por ultrafiltração: Estudo de caso na represa Guarapiranga. 2008. Dissertação de mestrado apresentada à Escola Politécnica da Universidade de São Paulo. São Paulo - SP

SOUZA, A. F. S. Diretrizes para implantação de sistemas de reúso de água em condomínios residenciais baseadas no método APPCC - análise de perigos e pontos críticos de controle: estudo de caso Residencial Valville I. 2008 .Dissertação de mestrado apresentada à Escola Politécnica da Universidade de São Paulo. São Paulo - SP

REBOUÇAS, A. C. Águas Doces no Mundo e no Brasil. In: REBOUÇAS, A. Cunha, BRAGA, Benedito e TUNDISI, José Galícia (Orgs). Águas Doces no Brasil: Capital ecológico, uso e conservação. $3^{\mathrm{a}}$ Edição. São Paulo, Escrituras editora, 2002.

U.S. Eviromental Protection Agency.(USEPA) 2004. Guidelines for Water Reuse.

VAN HAANDEL, A. e MARAIS, A. O comportamento do sistema de lodos ativados - Teoria e aplicações para projetos e aplicações. $1^{a}$ Edição. Campina Grande, 1999

VIANA, P. Z. Biorreatores com Membranas Aplicado ao Tratamento de Esgoto Doméstico: Avaliação do Desempenho de Módulos de Membranas com Circulação Externa. 2004. Dissertação de Mestrado submetida à Universidade Federal do Rio de Janeiro. Rio de Janeiro - RJ. 
ZEMAN, L.J e ZYDNEY, A. L. Microfiltration and Ultrafiltration: Principles and Applications. Dekker. New York, 1996.

WAGNER, J. Membrane Filtration Handbook - Pratical tips and hints. Second Edition, revision 2. Osmonics Filtration and Separation Group. Minnetonka, 2001.

WIESNER, M. R. Mass Transport and Permeate Flux and Fouling in PressureDriven Processes. Chapter 4 in: AWWA Resarch Foundation, Lyonnaise de Eaux, South Africa Wather Research Commission. Treatment Membrane Processes. McGraw- Hill. 1996.

WINTEGENS, T. et. al. The role of membrane processes in municipal wastewater reclamation and reúso. Desalination, vol. 178 p.1-11, Germany, 2005.

WNAG, Y.; WANG, Q.; GAO, B.; YUE, Q.; ZHAO Y. The disinfection by-products precursors' removal efficiency and the subsequent effects on chlorine decay or humic acid synthetic water treated by coagulation process and coagulationultrafiltration process. Chemical Engineering journal, p. 193-194, China,2012 


\section{9 - ANEXOS}

\section{Anexo 1 - Catálogo da membrana utilizada no experimento}

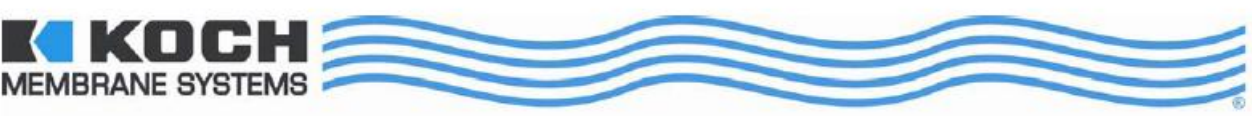

\section{ROMICON ${ }^{\circledR}$ CARTRIDGE: HF 5043-66-45-XM50P Industrial Hollow Fiber Ultrafiltration Module For Wastewater Treatment}

\begin{tabular}{|c|c|c|c|c|}
\hline $\begin{array}{l}\text { PRODUCT } \\
\text { DESCRIPTION }\end{array}$ & $\begin{array}{l}\text { KMS Part Number (KPN): } \\
\text { Membrane Chemistry: } \\
\text { Membrane Type: } \\
\text { Membrane Area: } \\
\text { Molecular Weight Cut-off: } \\
\text { Housing Construction: } \\
\text { Seal: }\end{array}$ & \multicolumn{3}{|c|}{$\begin{array}{l}0720190 \\
\text { Acrylonitrile co-polymer } \\
\mathrm{XM} \\
66 \mathrm{ft}^{2}\left(6.1 \mathrm{~m}^{2}\right) \\
50,000 \text { Dalton (nominal) } \\
\text { PVC } \\
\text { Epoxy }\end{array}$} \\
\hline \multirow[t]{2}{*}{$\begin{array}{l}\text { OPERATING AND } \\
\text { DESIGN } \\
\text { INFORMATION* }\end{array}$} & $\begin{array}{l}\text { Maximum Inlet Pressure: } \\
\text { Maximum Transmembrane Pressure: } \\
\text { Maximum Operating Temperature (at pH 8.0): } \\
\text { Maximum Permeate Side Back Pressure: } \\
\text { Maximum Feed Side Pressure Drop: } \\
\text { Allowable pH: }\end{array}$ & \multirow{2}{*}{\multicolumn{3}{|c|}{$\begin{array}{l}30 \mathrm{psi} @ 77^{\circ} \mathrm{F}\left(2.1 \mathrm{bar} @ 25^{\circ} \mathrm{C}\right) \\
25 \mathrm{psi} @ 77^{\circ} \mathrm{F}\left(2.1 \mathrm{bar} @ 25^{\circ} \mathrm{C}\right) \\
113^{\circ} \mathrm{F}\left(45^{\circ} \mathrm{C}\right) \\
20 \mathrm{psi}(1.4 \mathrm{bar}) \\
25 \mathrm{psi} @ 113^{\circ} \mathrm{F}\left(1.7 \mathrm{bar} @ 45^{\circ} \mathrm{C}\right) \\
1.5-13.0 @ 113^{\circ} \mathrm{F}\left(45^{\circ} \mathrm{C}\right)\end{array}$}} \\
\hline & "Consult Process Technology Group for specific applications & & & \\
\hline \multicolumn{5}{|l|}{$\begin{array}{l}\text { PRODUCT } \\
\text { DIMENSIONS }\end{array}$} \\
\hline & $\begin{array}{c}\text { A } \\
\text { inches }(\mathrm{mm})\end{array}$ & $\begin{array}{c}\text { D } \\
\text { inches }(\mathrm{mm})\end{array}$ & $\begin{array}{l}\text { Permeate } \\
\text { Connection }\end{array}$ & $\begin{array}{l}\text { Process } \\
\text { Connection }\end{array}$ \\
\hline & $43(1,092)$ & $4^{13 / 16(122)}$ & $11 / 2^{\prime \prime} \mathrm{NPSM}$ & 6" NPSM \\
\hline
\end{tabular}




\section{MEMBRANE INCOMPATIBILITY}

Prior to exposing the membrane to any chemical, the chemical should be reviewed by Koch Membrane Systems. Aside from the listed chemicals below, synthetic coolants, semi-synthetic coolants, kerosenes, naphtha, gasoline, floc polymers may affect membrane performance.

Chemicals that should be avoided include the following:

- Aprotic Solvent (e.g., Dimethyl Formamide, Dimethyl Acetamide, N-Methyl Pyrolidine, etc.)

- Chlorinated Solvents ( e.g., Methylene Chloride, Chloroform, Carbon Tetrachloride, etc.)

- Ketones (e.g., Acetone, Diacetone Alcohol, etc.)

- Silicones or Silicone based Defoamers (e.g., Siloxane )

\section{SERVICE AND ONGOING TECHNICAL SUPPORT}

Koch Membrane Systems, Inc. has an experienced staff of professionals available to assist end-users and OEMs for optimization of existing systems and support the development of new applications. Along with the availability of supplemental technical bulletins, Koch Membrane Systems, Inc. also offers a complete line of KOCHKLEEN` cleaning chemicals. 